\title{
RESPONSABILIDAD DEL ESTADO LEGISLADOR: CRITERIO DE RESPONSABILIDAD ADMINISTRATIVA POR EL DAÑO ANTIJURÍDICO DERIVADO DE LA ACTUACIÓN U OMISIÓN DEL CONGRESO DE LA REPÚBLICA EN COLOMBIA
}

\author{
Presentado por: \\ HELIANA ANGELICA SUÁREZ TIQUE
}

Director:

GABRIEL BARRETO FERRO

UNIVERSIDAD SANTO TOMAS

FACULTAD DE DERECHO

CONVENIO USTA-UNIVERSIDAD DE KONSTANZ (ALEMANIA)

MAESTRÍA EN DERECHO PÚBLICO

6 COHORTE

BOGOTÁ, D.C.- COLOMBIA

2014 
TABLA DE CONTENIDO

Pág.

INTRODUCCIÓN

1. GENERALIDADES DE LA RESPONSABILIDAD PATRIMONIAL EXTRACONTRACTUAL DEL ESTADO

1.1. EVOLUCIÓN DE LA RESPONSABILIDAD PATRIMONIAL DEL ESTADO

1.2. NOCIÓN DE RESPONSABILIDAD DEL ESTADO

1.3. ELEMENTOS DE LA RESPONSABILIDAD PATRIMONIAL EXTRACONTRACTUAL DEL ESTADO

1.3.1. Actividad del Estado, consistente en un hecho, omisión u operación administrativa

1.3.1.1. Los hechos administrativos

1.3.1.2. La operación administrativa

1.3.1.3. La omisión administrativa

1.3.1.4. La vía de hecho administrativa 17

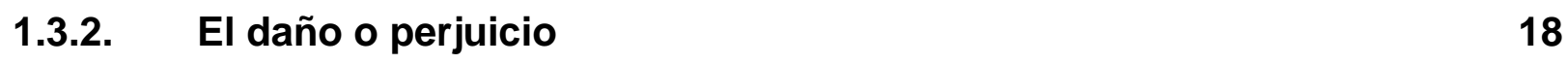

$\begin{array}{ll}\text { 1.3.3. La relación de causalidad } & 19\end{array}$

1.4. REFLEXIÓN 20

2. LA RESPONSABILIDAD PATRIMONIAL EXTRACONTRACTUAL DEL ESTADO EN COLOMBIA

2.1. MARCO CONSTITUCIONAL DE LA RESPONSABILIDAD PATRIMONIAL EXTRACONTRACTUAL DEL ESTADO

2.2. MARCO LEGAL DE LA RESPONSABILIDAD PATRIMONIAL EXTRACONTRACTUAL DEL ESTADO

2.3. SISTEMAS DE IMPUTACIÓN DE RESPONSABILIDAD PATRIMONIAL EXTRACONTRACTUAL DEL ESTADO EN COLOMBIA 
2.3.1. Régimen de Responsabilidad Subjetiva del Estado 29

2.3.1.1. Responsabilidad por falla del servicio presunta 31

2.3.1.2. Responsabilidad por falla del servicio anónima 32

2.3.2. Régimen objetivo de responsabilidad del Estado 33

2.3.2.1. Régimen de responsabilidad del Estado por el riesgo excepcional 35

2.3.2.2. Régimen de responsabilidad del Estado por el daño especial 38

2.3.2.3. Régimen de responsabilidad del Estado por ocupación de inmuebles por trabajos públicos 41

2.4. REFLEXIÓN 42

3. LA RESPONSABILIDAD DEL ESTADO LEGISLADOR 43

3.1. EL RECONOCIMIENTO DE LA RESPONSABILIDAD DEL ESTADO LEGISLADOR 43

$\begin{array}{lll}\text { 3.1.1. } & \text { El perjuicio especial } & 58\end{array}$

3.1.2. El enriquecimiento sin causa 58

3.2. REFLEXIÓN 59

4. ASPECTOS PUNTUALES DE LA RESPONSABILIDAD DEL ESTADO LEGISLADOR FRENTE AL DERECHO COMPARADO 61

4.1. $\quad$ FRANCIA 61

4.2. ALEMANIA 68

4.3. ESPAÑA

$\begin{array}{lll}\text { 4.4. ITALIA } & 86\end{array}$

4.5. UNIÓN EUROPEA

$\begin{array}{lll}\text { 4.6. } & \text { CHILE } & 94\end{array}$

$\begin{array}{lll}\text { 4.7. } & \text { REFLEXIÓN } & 97\end{array}$

5. LA RESPONSABILIDAD DEL ESTADO LEGISLADOR EN $\begin{array}{ll}\text { COLOMBIA } & 98\end{array}$

5.1. FUNDAMENTO CONSTITUCIONAL 98

5.2. TRATAMIENTO DE LA RESPONSABILIDAD DEL ESTADO LEGISLADOR POR LA JURISPRUDENCIA CONSTITUCIONAL 110 COLOMBIANA 
5.3. TRATAMIENTO DE LA RESPONSABILIDAD DEL ESTADO LEGISLADOR POR LA JURISPRUDENCIA CONTENCIOSO- 114 ADMINISTRATIVA COLOMBIANA Y TÍTULOS DE IMPUTACIÓN

5.4. MECANISMO DE CONTROL PARA RECLAMAR PERJUICIOS 136 DERIVADOS DE LA ACTIVIDAD DEL LEGISLADOR Y TRÁMITE

5.5. OPORTUNIDAD PARA EJERCER EL DERECHO DE ACCIÓN POR 139 RESPONSABILIDAD DEL ESTADO LEGISLADOR - CADUCIDAD

5.6. REFLEXIÓN 142

CONCLUSIONES 144

BIBLIOGRAFÍA 148 


\section{INTRODUCCIÓN}

El artículo 90 de la Constitución Política colombiana determinó claramente la indemnización como consecuencia del daño antijurídico, marcando un punto de evolución en la concepción de la imputación al Estado de la responsabilidad patrimonial por los daños causados por sus agentes. Este artículo establece la responsabilidad patrimonial del Estado por los daños antijurídicos que le sea imputables, causados por la acción o la omisión de las autoridades públicas.

En Colombia, pese a esa supuesta obligación que tienen los ciudadanos de soportar ciertas cargas o daños por causa de la acción estatal, la Carta Política precisa que no existe deber jurídico de soportar aquel daño o lesión especialmente grave, que exceda por su magnitud las cargas habituales. De hecho, cuando de la atribución de cargas se genera un daño desproporcionado, éste se torna antijurídico y, en tal evento, surge el derecho a la reparación, independientemente de la legitimidad o no de la conducta de la autoridad pública.

Dentro de tal contexto, los hechos provenientes de actividades legislativas pueden causar daños antijurídicos a los administrados cuando se configura el rompimiento del equilibrio de las cargas públicas, por medio del cual un administrado en concreto ve afectado un derecho sin tener el deber legal de soportarlo. A todas luces, este daño antijurídico es ocasionado por la actividad del Estado Legislador.

El origen de la obligación de reparar el daño producido por parte del legislador radica en la situación de desigualdad provocada por la norma legal, que repercute perjudicialmente sobre un individuo respecto del resto de la colectividad.

Ahora bien, sobre la necesidad de determinar el régimen de responsabilidad que se aplicaría al legislador -a efectos de precisar si se requiere del examen de la conducta propio del régimen subjetivo-, o si basta con la acreditación de la antijuridicidad del 
daño como se verifica en los regímenes objetivos, prescindiendo entonces de la prueba de la negligencia o culpa desplegada, "la exigencia de deber compensatorio al Parlamento plantea la indagación del régimen de responsabilidad que ha de regir la misma, estableciendo claramente el lugar de ubicación de la antijuridicidad" (Alonso García, 1999: p. 12).

En virtud de lo expuesto, la presente investigación se trazó como objetivo general: Establecer si en el marco jurídico colombiano es posible imputar un daño antijurídico indemnizable al Estado por la actividad legislativa.

La escogencia de este trabajo de investigación "la responsabilidad del Estado Legislador en Colombia: Criterio y fundamentos jurídicos de imputación de responsabilidad administrativa", se debe entonces a que en la actualidad es objeto de álgido cuidado si la actividad legislativa del Congreso de la República -como actividad de autoridad pública-, es o no ajena a los parámetros, propósitos y fines descritos en la Constitución, de tal modo que cuando el legislador mediante su acción u omisión causa un daño antijurídico y vulnera derechos de los administrados, debe resarcir los perjuicios ocasionados, originando la responsabilidad patrimonial del Estado.

Asimismo, la utilidad de la investigación se colige, toda vez que en Colombia aún es escasa la bibliografía sobre el tema, lo cual ha conducido a agudas controversias en la doctrina, la jurisprudencia y la academia -no sólo nacional sino extranjera, en especial-, en lo referente a los fundamentos que debe asumir su régimen de imputación.

El estudio realizado es de tipo descriptivo debido a que se buscaron los criterios y fundamentos jurídicos de imputación de responsabilidad administrativa del Estado Legislador en Colombia, así como las propiedades importantes o componentes del fenómeno a indagar. La investigación se llevó a cabo mediante la aplicación del método científico, puesto que se pretendió proporcionar una herramienta útil de consulta que permita tener un acercamiento al fenómeno de la responsabilidad del Estado Legislador en Colombia. 
Adicionalmente, como métodos aplicables a la investigación, se utilizaron el método lógico-inductivo y el método lógico-deductivo, con el fin de cumplir con los objetivos propuestos de un modo satisfactorio.

En este orden de ideas, la investigación se desarrolló de la siguiente forma:

El primer capítulo se encuentra dedicado a abordar las generalidades de la responsabilidad patrimonial extracontractual del Estado. Por su parte, el segundo capítulo estudia la responsabilidad patrimonial extracontractual del Estado en Colombia, el marco constitucional y legal, desarrollo jurisprudencial y títulos de imputación aplicados en nuestro país. El tercer capítulo, a su vez, estudia la responsabilidad del estado legislador, su reconocimiento y desarrollo jurisprudencial. A su turno, el cuarto capítulo realiza un estudio de la responsabilidad del Estado Legislador en el Derecho Comparado, analizando dicha institución en países que han tenido una destacada influencia en materia de Responsabilidad del Estado para el sistema jurídico colombiano, como por ejemplo: Francia, Alemania, España, Italia, la Unión Europea y Chile. El capítulo quinto es dedicado al estudio de la Responsabilidad del Estado Legislador en Colombia, su fundamento constitucional, el desarrollo que ha tenido el tema en la jurisprudencia y los aspectos procedimentales para invocar la declaratoria de responsabilidad del Estado con ocasión del daño antijurídico causado por la actividad del Legislador. Finalmente, se exponen una serie de conclusiones. 


\section{GENERALIDADES DE LA RESPONSABILIDAD PATRIMONIAL EXTRACONTRACTUAL DEL ESTADO}

\subsection{EVOLUCIÓN DE LA RESPONSABILIDAD PATRIMONIAL DEL ESTADO}

La aceptación de la responsabilidad patrimonial del Estado, cuando éste desarrolla su actividad en el ámbito del derecho público, fue de tardía aparición en la historia. Es indudable que la idea de soberanía jugó un papel fundamental en el mantenimiento durante varios siglos, del principio de la irresponsabilidad del Estado (Cassagne, 2002, T. I: p. 265), puesto que como dicho dogma era entendido -según Bodino-, como "el poder supremo sobre los ciudadanos y súbditos, no sometido a las leyes" (Naranjo Mesa, 1995: p. 218), hizo que el mundo occidental creyera en esa soberanía, al ser atributo esencial del Estado y no simplemente un atributo personal del monarca, y volviera a aquél irresponsable y lo constituyera en fuente de derecho, esto es, no sometido a las leyes.

De este modo, hasta el momento en que se instaura plenamente el Estado de Derecho, lo característico de la soberanía era imponerse a todos sin compensación (Soriano García, 1993: p. 98), particularidad que encontró su expresión clásica en el principio según el cual "the king can do not wrong", "Le Roi ne peut mal faire" ('el rey no puede hacer ilícito'), común a todo el mundo occidental (Bullrich, 1920: pp. 254-255; Bustamante Ledesma, 2003: pp. 5-6; Colombo, 1947: pp. 464-481; García de Enterría \& Fernández, 1981, T. II: p. 323; Jeze, T. I: pp. 212-247; Linares Quintana, 1946, T. II: pp. 338-384; Rivero, 1984: p. 297; Rodríguez R., 1995: pp. 372-374; Sayagués Laso, 1963, T. I, pp. 628-629). Así entonces, en la antigüedad no se concebía un Estado responsable por los daños con que su actividad pudiera causar a los ciudadanos, y por esa razón tenía amplios poderes para disponer de la vida, integridad y bienes de los asociados, no siendo responsable de su utilización sino ante las divinidades (Bustamante Ledesma, 2003: p. 5). 
La característica enunciada de la irresponsabilidad del Estado, traspasó perfectamente el umbral revolucionario francés de finales del siglo XVIII y llegó a constituirse en moneda corriente en el régimen constitucional (García de Enterría \& Fernández, 1981, T. II: p. 323), puesto que con la Revolución Francesa, "sustituyó la soberanía del monarca por la soberanía del pueblo, articulada sobre la idea del predominio de la voluntad general, considerada soberana e infalible (J. J. Rousseau) y no obstante que (al menos teóricamente) los hombres se vinculan y unen sus voluntades en un contrato social, la soberanía del pueblo no reconoce limitaciones, acentuándose así el despotismo y la irresponsabilidad del Estado" (Cassagne, 2002, T. I: pp. 265-266). Sin embargo, en las Asambleas Revolucionarias francesas se discutió este tema al tiempo que ciertas minorías intentaban consolidarlo, creando el germen de lo que, andando el tiempo, será el fundamento de la responsabilidad administrativa patrimonial del Estado (Leguina Villa, 1983: p. 151).

La justicia y el progreso de la ciencia jurídica no podrían permitir por más tiempo el mantenimiento de un principio tan lesivo a los derechos del individuo, en cuanto que sin el reconocimiento de la responsabilidad del Estado carecían de sentido las garantías que los ordenamientos constitucionales o supremos que cada país estatuían, precisamente para la protección de tales derechos (Cassagne, 2002, T. I, p. 266).

De este modo, poco a poco fue reconociéndose la necesidad de establecer normas pertinentes a fin de no dejar inerme al ciudadano frente a la acción del Estado, de modo que pudiera causarle daño en sus bienes o derechos (Garrido Mayol, 2004: p. 14). Así, la situación de irresponsabilidad del Estado es superada por obra del llamado Estado de Derecho, puesto que no reconoce poderes jurídicos absolutos e ilimitados (Cassagne, 2002, T. I: p. 266), y además que traduce, inicialmente, en la proclamación de la Ley como máxima expresión de la soberanía popular y en el sometimiento de todos, incluyendo a los poderes públicos, a lo dispuesto en ella. 
Por consiguiente, el Estado de Derecho presupone una autolimitación de sus propios poderes por parte del mismo, que permite, frente a él, un ensanchamiento de la esfera jurídica del administrado, ensanchamiento que incluye la responsabilidad estatal por medio de actos o hechos que le sean jurídicamente imputables (Marienhoff, 1987, T. IV: p. 692, §1628), lo cual supuso una gran conquista para el ciudadano, debido a que el mismo comprende un sistema de garantía efectiva patrimonial, no sólo frente a los despojos expropiatorios que legítimamente el poder público pueda realizar para llevar a cabo sus tareas en pos de la satisfacción eficaz de las necesidades colectivas, sino que dicha garantía debe también extenderse, sin la menor duda, a aquellos daños que voluntariamente -y la mayor parte de las veces involuntariamente en el desenvolvimiento de sus quehaceres-, el poder público causa a los ciudadanos, según sea en relaciones contractuales o en relaciones extracontractuales (Leguina Villa, 2000: p. 2). La responsabilidad patrimonial del Estado aparece, de este modo, "como un límite del poder del Estado en factor de la libertad individual" (Garrido Mayol, 2004: p. 15).

Fue en Francia donde se inició el proceso de formación de los sistemas jurídicos tendientes a asegurar las reparaciones a los particulares afectados por la actividad de la administración, ${ }^{1}$ sin necesidad de acudir a la interpretación forzada de normas reguladoras de relaciones privadas.

\footnotetext{
${ }^{1}$ En los Estados Unidos de Norteamérica -señala Jawitt en su Dictionary of the English Law de 1965-, no se consideraba como principio general la responsabilidad del Estado, por lo que en derecho anglosajón se llaman 'torts'. Un 'torts' se define como "un acto indebido que lesiona a alguien en un derecho distinto del que nace de un contrato y por el cual un agraviado puede ejercer acción legal (...) es todo acto inmoral, indebido o injusto" (Carrillo Flores, 1987: p. 14).

Apenas en 1922, una ley norteamericana concedió a los departamentos del Ejecutivo para otorgar indemnizaciones hasta por 1000 dólares, cuando el daño era causado a la propiedad. La situación en Gran Bretaña era en 1939 fundamentalmente igual a la de Estados Unidos: como el rey o la reina nunca pueden hacer un acto injusto, los particulares no podían pedir que se les indemnizase por los 'torts' cometidos por los servidores públicos de su majestad (Carrillo Flores, 1987: p. 14).

Sin embargo, la situación en Estados Unidos y en Gran Bretaña ha variado su orientación con respecto a la responsabilidad patrimonial del Estado; por ejemplo, en este último país -a partir de la sanción de la "Crown Procedings Acts" en 1947- se evolucionó sobre el particular radicalmente, puesto que se admitió la responsabilidad patrimonial de la Corona con relativa amplitud, exceptuándose ciertos casos expresamente previstos en la ley. Estados Unidos, a su turno, en 1946 fue sancionada la "Federal Court Claims Act", admitió genéricamente, sin perjuicio de ciertas excepciones, la posibilidad de accionar en vía jurisdiccional, reclamando la reparación pecuniaria por responsabilidad extracontractual del Estado (García de Enterría y Fernández, 1981: pp. 324-325; Sayagués Laso, 1963: pp. 627-631).
} 
En efecto, el proceso se inicia con la organización jurisdiccional de un tribunal de competencia bien definida, como lo es el Consejo de Estado francés, corporación que ha podido por obra puramente jurisprudencial -casi consuetudinaria-, crear todo un cuerpo armónico de principios que garantizan al particular, ya no solamente la anulación del acto ilegítimo, sino la responsabilidad del Estado, por actuaciones administrativas lesivas al interés privado, a través de toda la jurisprudencia construida alrededor del concepto "culpa del servicio público". Asimismo, dicho tribunal descartó la aplicación de los textos del Código Civil y declaró la competencia exclusiva de la jurisdicción contencioso-administrativa para el conocimiento de las demandas sobre responsabilidad extracontractual de las entidades públicas, en oposición a lo sostenido por los tribunales de la justicia común (López Morales, 2001: T. I: p. 3), comenzando con la consagración de la responsabilidad del Estado por faltas objetivas en la prestación de servicios públicos, y llegando luego a la aceptación de la responsabilidad del Estado por causa de actos judiciales y legislativos.

Esta etapa fue inaugurada a través del célebre "arret Blanco" (fallo Blanco) del 8 de febrero de 1873, proferido por el Consejo de Estado francés (García de Enterría \& Fernández, 1983: pp. 328-329; López Morales, 2001: p. 3; Rodríguez R., 1995: pp. 372-373; Sayagués Laso, 1963: p. 621), mediante el cual se consagró la responsabilidad del Estado independientemente de que estuviera estatuida en textos legales expresos, e independientemente de su actividad de poder o gestión que desarrollara aquél, pues en esta decisión se tomó como fundamento la nueva noción de servicio público, que vino a reemplazar las de poder y de gestión (Rodríguez R., 1995: pp. 372-373).

A partir de ese momento, la evolución del derecho administrativo ha mostrado una tendencia evidente hacía una mayor responsabilidad del Estado cada día, ${ }^{2}$ aunque la evolución jurisprudencial francesa ha sido lenta, llena de matices y de salvedades,

\footnotetext{
2 Dentro de este contexto, es menester destacar también el fallo "Cadot" de diciembre 13 de 1889, así como el fallo 'Terrier' de febrero 6 de 1903 del Consejo de Estado de Francia (Long, Weil, Braibant, Delvolvé \& Genevois, 2009: pp. 67 y ss.)
} 
hasta llegar a concluir que existe una culpa específica en el funcionamiento de los servicios públicos cuando éstos han asumido cierta forma irregular de prestación -o de falta de prestación— perjudicial para un particular (Carrillo Flores, 1973: pp. 7-9).

En síntesis, puede afirmarse que en un comienzo regía el principio de la irresponsabilidad del Estado y de sus agentes (funcionarios y empleados); más tarde se aceptó la responsabilidad del agente público, no así la del Estado; luego la de ambos (agente y Estado), y finalmente la del Estado en forma directa. De manera que, así como originariamente la "irresponsabilidad" del Estado constituía el "principio", en la actualidad dicha "irresponsabilidad" constituye la "excepción". Tal es, a grandes rasgos, la evolución que experimentó lo atinente a la "responsabilidad del Estado" en el campo del derecho público.

En la actualidad, la responsabilidad patrimonial del Estado se erige como uno de los pilares fundamentales sobre los que descansa el llamado Estado social y democrático de Derecho.

\subsection{NOCIÓN DE RESPONSABILIDAD DEL ESTADO}

Etimológica y gramaticalmente, el término 'responsabilidad' está vinculado a una persona y proviene del vocablo latín 'respondere', que significa, 'inter alia': prometer, merecer, pagar. Así, 'responsalis' denota: "el que responde". De manera más restringida, 'responsum' significa: "el obligado a responder de algo o de alguien" (Tamayo y Salmoran, 1984, T. VIII: p. 44).

De manera general, la Real Academia española (2001, T. VIII: p. 1453) define la expresión 'responsabilidad' como:

Deuda, obligación de reparar y satisfacer, por sí o por otra persona, a consecuencia de un delito, de una culpa o de otra causa legal. Cargo u obligación moral que resulta para alguien del posible yerro en cosa o asunto determinado. Capacidad existente en todo sujeto activo de derecho para reconocer y aceptar las consecuencias de un hecho realizado libremente. 
Entretanto, en sentido jurídico, el maestro Cabanellas (1979: p. 283) define el término como la "obligación de reparar y satisfacer por uno mismo o, en ocasiones especiales, por otro, la pérdida causada, el mal inferido o el daño originado (...) El talión económico jurídico: la obligación de resarcir, en lo posible, el daño causado y los perjuicios inferidos por uno mismo o por un tercero, y sin causa que excuse de ello".

En el mismo sentido, pero de manera concreta, el tratadista español Parada (1993, T. I: p. 618) entiende el vocablo como "la posición del sujeto a cargo del cual la ley pone la consecuencia de un hecho lesivo sobre un interés protegido".

En este orden de ideas, la expresión responsabilidad no se define por su fundamento que puede variar-, sino por su resultado, es decir, por las consecuencias jurídicas que el hecho acarrea para el agente. De esta manera se aduce que una persona natural o jurídica es responsable cuando está obligada a indemnizar el daño. Jurídicamente existe responsabilidad cada vez que una persona natural o jurídica debe reparar el perjuicio o daño sufrido por otra. Puede definirse diciendo que es la obligación que pesa sobre una persona de reparar el daño sufrido por otra, como consecuencia de la reacción del ordenamiento jurídico frente al hecho dañoso, derivado de la violación del deber jurídico de no dañar a nadie.

Así las cosas, la institución de la responsabilidad patrimonial no supone ya un perjuicio social, sino un daño privado. Por eso, ya no es cuestión de penar, sino solamente de reparar. De hecho, la responsabilidad patrimonial es una reparación.

Pues bien, se tiene que después del acto administrativo, la fuente más amplia de consecuencias jurídicas para el Estado, es la responsabilidad patrimonial, puesto que en el cumplimiento de sus funciones y en el ejercicio de sus actividades, es comprensible que la Administración llegue a lesionar a los administrados o particulares, sea en sus derechos patrimoniales o no patrimoniales. De ahí surge la institución de la "responsabilidad del Estado", que puede ser entendida como la situación que se origina cuando el administrado ha sufrido un daño o perjuicio en desarrollo de la actividad 
estatal (Marienhoff, Miguel S., 1987: pp. 690-691, §1624). Esta responsabilidad es la consecuencia jurídica de la relación de hecho descrita, es decir, la obligación del Estado de resarcir el perjuicio ocasionado; de tal modo, se advierte que la responsabilidad estatal se resuelve en todos los casos en una obligación de reparación del interés legítimamente protegido.

Lo anterior se inspira en el principio romano contenido en la 'Lex Aquilia' (Petit, 1994: pp. 454 y ss.), según la cual se establecía que quien produce un daño está obligado a repararlo; de ahí que sea válido afirmar que el Estado como persona está sometido al derecho, no debe quedar excluido de esta obligación (Rodríguez R., 1995: pp. 367 y ss.). Además, dicho instituto jurídico, que se rige por los principios del Derecho Administrativo, deviene de la obligación que tiene el Estado de proteger a los ciudadanos contra decisiones arbitrarias e ilícitas de la Administración pública y de sus funcionarios, reparando el daño causado mediante una compensación económica que restituya el perjuicio patrimonial e inclusive moral que el Estado ocasione como consecuencia de la actividad administrativa que desempeña en cumplimiento de las funciones que le han sido encomendadas por la Constitución y la ley (Pineda, 1984, T. VIII: pp. 47-48).

La responsabilidad del Estado -como en general la de todo ente jurídico-, puede ser contractual o extracontractual; y esta distinción obedece a si la responsabilidad nace con motivo del incumplimiento por parte del Estado de obligaciones 'convenidas', o de lo contrario, que esté obligado a responder por hechos, omisiones u operaciones de personas que estén bajo su dependencia -o de las cosas de que se sirve-, originada del principio general de no hacer daño a otro.

La responsabilidad contractual presupone la existencia de una relación jurídica anterior a la ocurrencia del daño, que específicamente deviene de la celebración de un contrato; por ello mismo, requiere el incumplimiento de un deber jurídico concreto y determinado. Por el contrario, la responsabilidad extracontractual, que es la que interesa para el presente estudio, es ajena a una relación o vínculo jurídico contractual, 
y nace simple y llanamente con ocasión de un daño a una persona con la cual el Estado no tiene ninguna relación jurídica anterior (Parada, 1993, T. I: p. 618).

Ahora bien, efecto de la responsabilidad del Estado es el deber de reparación por el daño ocasionado. Luego, entrando ya en el estudio sumario de la cuestión relativa a la reparación del daño, es preciso advertir que la persona natural o jurídica afectada por la actividad del Estado podrá deprecar la compensación de los daños que sean ciertos, directos, personales, y que hayan causado la supresión de un beneficio obtenido lícitamente por el lesionado. Esta reparación ha de comprender tanto los perjuicios patrimoniales como los extrapatrimoniales.

Dicha reparación comprende el restablecimiento del statu quo ante el resarcimiento de los perjuicios. Así las cosas, es menester observar la diversidad de naturaleza entre la indemnización y el resarcimiento. Ciertamente, mientras el resarcimiento verdadero y propio del daño debe tender, en lo posible, a la reposición del interés lesionado a su estado anterior, debiendo limitarse al equivalente económico a los casos en que tal reposición no sea posible, la indemnización, por el contrario, por su propia naturaleza, no puede consistir en otra cosas que en el equivalente económico de la lesión (Alessi, 1970, T. II: p. 501).

Si el daño deriva sólo parcialmente de dicha actividad porque en su producción concurran concausas, la reparación a satisfacer deberá cubrir el daño sólo parcialmente, en proporción a la participación que la actividad de la Administración Pública haya tenido en su producción (Alessi, 1970, T. II: p. 500).

\subsection{ELEMENTOS DE LA RESPONSABILIDAD PATRIMONIAL EXTRACONTRACTUAL DEL ESTADO}

Tradicionalmente, se ha señalado que la responsabilidad patrimonial extracontractual del Estado requiere la concurrencia de los siguientes elementos: 
- Actividad del Estado, consistente en un hecho, omisión u operación administrativa;

- La existencia de un daño;

- Un nexo de causalidad entre éste y aquélla.

Teniendo presente la necesidad de la concurrencia de estos tres elementos, podemos pasar a estudiarlos más ampliamente cada uno:

\subsubsection{Actividad del Estado, consistente en un hecho, omisión u operación administrativa}

Para que una entidad pública pueda ser considerada responsable de algo, debe haberse producido ante todo una actuación de la que haya sido autora (Rodríguez R., 1995: p. 369).

La actividad del Estado en relación con el cumplimiento de sus funciones, deberes y competencias puede tener múltiples manifestaciones en las cuales se compromete la responsabilidad estatal, bien sea cuando obran defectuosamente o cuando omiten el ejercicio de esas funciones (Bustamante Ledesma, 2003: p. 42). De este modo, desde el punto de vista jurídico, la actividad del Estado reflejada inicialmente en actos administrativos, también se manifiesta a través de otros mecanismos jurídicos de actuación, dentro de las cuales podemos incluir: los hechos, las operaciones, las omisiones y las vías de hecho administrativas.

\subsubsection{Los hechos administrativos}

Enseña el maestro Libardo Rodríguez, que los hechos administrativos "son aquellos fenómenos, acontecimientos o situaciones que se producen independientemente de la voluntad de la administración, pero que producen efectos jurídicos respecto de ella" (1995: p. 186). Bustamante Ledesma, entre tanto, sostiene que el hecho administrativo

\footnotetext{
"se presenta cuando un agente del Estado en razón de las funciones propias de su cargo observa un comportamiento positivo que lesiona el interés ajeno o bien cuando incurre en omisiones en el cumplimiento de sus deberes, cuyos efectos jurídicos no están, en sus consecuencias jurídicas, reguladas expresamente por la Ley" (2003: p. 45).
} 


\subsubsection{La operación administrativa}

Para Bustamante Ledesma, la operación administrativa se concibe como "el ejercicio de un derecho reglamentado en provecho de la administración y mediante el procedimiento previamente establecido" (2003, p. 44). El tratadista Libardo Rodríguez, entre tanto, señala que

son aquellos fenómenos jurídicos que consisten en la reunión de una decisión de la administración junto con su ejecución práctica, en tal forma que constituyen en conjunto una sola actuación de la administración (...) Es decir, para que se presente la figura de la operación administrativa se requiere la existencia de una decisión de la administración, o sea, de un acto, el cual puede ser expreso o tácito (1995: p. 186).

Así las cosas, la operación administrativa requiere la presencia de un derecho reconocido y reglamentado en beneficio del Estado y la utilización por parte de sus agentes del procedimiento correspondiente, en orden a hacerlo efectivo. Tratándose de la responsabilidad extracontractual del Estado, la operación administrativa no se refiere al trámite o procedimiento que debe cumplirse para la expedición de un acto definitivo sino más propiamente al conjunto de los actos materiales de ejecución de una decisión o acto administrativo. La característica fundamental de esta figura está conformada por la transformación del ámbito externo, como efecto de la ejecución material de una resolución, y en ello radica su diferencia con la producción del acto administrativo complejo o definitivo (Bustamante Ledesma, 2003: p. 44).

\subsubsection{La omisión administrativa}

El profesor Libardo Rodríguez las define como "las abstenciones de la administración que producen efectos jurídicos respecto de ella" (1995: p. 187). Es decir, que la omisión administrativa consiste en la inejecución de ciertas obligaciones positivas impuestas a determinada entidad pública a favor del público, o bien en la omisión de un acto o en la falta de una intervención o de una iniciativa, cuando se les considera como deberes jurídicos positivos. 


\subsubsection{La vía de hecho administrativa}

Puede hablarse que existe vía de hecho administrativa,

cuando la Administración obra en ejercicio de un pretendido derecho que realmente no tiene, o cuando en ejercicio de un derecho que realmente tiene obra con ausencia total del procedimiento legal o aplica otro distinto al señalado por la Ley, es decir, es la arbitrariedad de la Administración la que queda escuetamente a la observación" (C.E., sentencia del 28 de octubre de 1976).

De manera que, una vía de hecho, equivale a la usurpación del poder, a la arbitrariedad, a la violencia o, como algunos autores la denominan, a la actuación cuasidelictual de la administración.

En este orden de ideas, la vía de hecho se configura y caracteriza por dos elementos esenciales: por una parte, cuando la Administración ha pretendido ejercitar un derecho que ni la Constitución ni la ley le otorgan; por otra, cuando la Administración obra sin observar el procedimiento que se le ha impuesto.

\subsubsection{El daño o perjuicio}

El daño constituye un elemento esencial dentro de la responsabilidad patrimonial extracontractual del Estado, puesto que si no existe daño, tampoco puede haber una acción tendiente a repararlo.

La doctrina nos da un concepto de lo que significa el daño: consiste en todo detrimento, menoscabo, dolor, molestia que sufre un individuo en su persona, bienes, libertad, honor, crédito, afectos, creencias, etc. (Bustamante Ledesma, 2003: p. 49; Fiorini, 1968, T. II: p. 1114; Sayagués Laso, 1963: pp. 661-663).

El daño o perjuicio se subdividen en material o moral. El daño o perjuicio material es el que consiste esencialmente en una disminución o quebranto de un bien en un sentido pecuniario, y que puede afectar a una persona en su patrimonio, como destruyendo o desmejorando bienes raíces o mobiliarios; o en su persona física, como un accidente de locomoción, el error de un médico, cirujano o farmacéutico. 
El daño o perjuicio moral es el que sobreviene de la actividad de la Administración que ofende, no los derechos patrimoniales ni la persona física, sino la personalidad moral del damnificado, hiriendo uno de sus intereses legítimos o bienes no económicos de los que integran lo que generalmente se llama patrimonio moral de una persona.

A su vez, el daño moral sufre una subdivisión: en perjuicios morales propiamente dichos y en perjuicios de afección y / o fisiológicos : los perjuicios morales que son los que afectan la parte social del patrimonio moral, como los atentados contra el honor y la reputación, las consideraciones sociales, protegidos por las leyes que sancionan la calumnia, la injuria, la difamación; y en perjuicios de afección que son los que hieren la parte afectiva del patrimonio moral, las convicciones y sentimientos de amor, dentro de las vinculaciones familiares, como la pérdida o el daño a personas queridas o la destrucción o deterioro de objetos materiales representativos de valor de afección.

Adicionalmente, para que el daño merezca ser considerado en materia de responsabilidad patrimonial extracontractual del estado, es preciso que el mismo sea 'antijurídico', no ya porque la conducta de su autor sea contraria a Derecho (antijuridicidad subjetiva), sino, más simplemente, porque el sujeto que lo sufre no tenga el deber jurídico de soportarlo (antijuridicidad objetiva). De manera que la antijuridicidad susceptible de convertir el daño en lesión reparable se predica, pues, del efecto de la actuación administrativa (no de la actuación del agente de la Administración causante material del daño), a partir de un principio objetivo de garantía de los derechos subjetivos de los ciudadanos que despliega su operatividad, postulando la cobertura del daño causado en tanto no existan causas de justificación que legitimen como tal el perjuicio de que se trate (García de Enterría \& Fernández, 1983: p. 338).

Esas causas de justificación han de ser expresas para que puedan ser estimadas y deben consistir siempre en un título que determine o imponga como jurídicamente querido o aceptado el perjuicio contemplado. Así, por ejemplo, el cumplimiento de una 
obligación expresamente impuesta por la ley (García de Enterría \& Fernández, 1983: p. 338).

\subsubsection{La relación de causalidad}

La relación causal es el tercer elemento de la responsabilidad patrimonial extracontractual del Estado. En efecto, la existencia de una relación de causa a efecto entre la actividad de la administración y el daño causado es, lógicamente, una condición indispensable para que pueda atribuirse a aquélla el deber de resarcir dicho daño.

Se entiende por relación de causalidad, el vínculo existente entre el daño o perjuicio y la actividad de la Administración Pública. Luego es necesario que el perjuicio pueda atribuírsele a la actividad del Estado.

De esta suerte, en presencia del efecto (daño) el operador jurídico debe determinar la causa que produjo el daño y si aquella es imputable al Estado. Si ese vínculo causal no puede demostrarse o si, por el contrario, se descubre un origen del daño totalmente diferente a la actividad de la Administración Pública, es claro que ésta no será responsable.

Sin embargo, es preciso advertir que para que una actividad de la Administración merezca ser considerada como causa del daño es preciso que sea en sí misma idónea para producirlo según la experiencia común, es decir, que tenga una especial aptitud para producir el efecto lesivo. Sólo en estos casos (causalidad adecuada) puede decirse, con rigor, que la actividad tomada en consideración constituye la causa eficiente, la causa próxima del daño ('in iure non remota causa, sed próxima spectatur), la causa verdadera del mismo (García de Enterría \& Fernández, 1983: p. 354). 


\subsection{REFLEXIÓN}

El principio de derecho que implica la obligación de responder por un daño, y de reparar sus consecuencias a los afectados, no es solamente de aplicación del Derecho Privado, puesto que desde finales del siglo XIX se superaron las posiciones doctrinales y jurisprudenciales, que no contemplaban un Estado sujeto a responsabilidades bajo la perspectiva de que cualquier actividad o acto desplegado en ejercicio del poder estatal por arbitrario, llegara a ser justificado en los propósitos o fines que el Estado persigue.

Así las cosas, hoy por hoy, y desde el fallo del Tribunal de Conflictos Francés -"el Fallo Blanco" en 1873-, se concibe y no se pone en duda que el Estado es responsable de los perjuicios que pueda ocasionar a un particular o a una entidad pública como consecuencia de un acto administrativo, un hecho administrativo, una omisión administrativa, una operación administrativa o una vía de hecho administrativa. 


\section{LA RESPONSABILIDAD PATRIMONIAL EXTRACONTRACTUAL DEL ESTADO EN COLOMBIA}

\subsection{MARCO CONSTITUCIONAL DE LA RESPONSABILIDAD PATRIMONIAL EXTRACONTRACTUAL DEL ESTADO}

Hasta la entrada en vigencia de la Constitución Política de 1991, no existía en el ordenamiento jurídico colombiano una cláusula general expresa de carácter superior sobre la responsabilidad patrimonial del Estado. Hoy por hoy, el principio de la responsabilidad del Estado está consagrado al mayor nivel por la Constitución Política, la cual "no sólo es fuente formal del derecho, sino que también expresa cuál es su ámbito de aplicación material" (Gil Botero, 2011: p. 290).

En efecto, a partir de 1991, en nuestro país existe una nueva concepción del Estado, de sus principios, de sus fines, de sus funciones y de su estructura (Ibáñez Najar, 2006: p. 130). El orden jurídico consagrado en la Carta Fundamental permite dar aplicación a principios y valores superiores ligados a la moderna concepción de justicia, como la solidaridad, la equidad y el Estado social de Derecho.

De este modo, el régimen constitucional, "trajo consigo una nueva dimensión en las relaciones de los ciudadanos frente al Estado, partiendo de la primacía del principio de la dignidad humana como rector de la nueva estructura jurídica y política y la concepción de la persona como un fin estatal" (C. Const., sentencia C-1062/00). Por consiguiente, la definición misma de Colombia, como un Estado social de Derecho, fundado por el respeto de la dignidad de la persona humana y en la solidaridad (Preámbulo y artículos 1 al 95 de la Constitución Política), permite manejar un amplio campo en cuanto a la responsabilidad del Estado con la solidez que la normativa superior tolera (C. Const., sentencia 571/92), puesto que congruente con el ejercicio del poder institucionalizado, se proclama la inevitable necesidad de hacer a los organismos públicos y a las personas a ellos vinculadas responsables de manera general frente al ordenamiento jurídico, y de manera personal cuando hubiesen desbordado los 
parámetros definidos para el ejercicio de sus funciones. Esta responsabilidad lleva las condenas patrimoniales a cargo de unos y otros en caso de generarse daños de carácter antijurídico que hicieren necesario restablecer en sus derechos o indemnizar a los asociados (Santofimio Gamboa, 2005: p. 259; Younes Moreno, 1994: pp. 255-257).

Ciertamente, la naturaleza social que identifica al Estado colombiano "tiene una sentida connotación de prevalencia de los derechos fundamentales, en la superación de la crisis del Estado de Derecho y en la inmediata tarea de recuperación social en sus niveles, dentro de un necesario desarrollo de los principios de solidaridad y dignidad humana, los cuales orientan el nuevo Estado social de derecho" (C. Const., sentencia T-571/92).

De tal forma, base fundamental de este esquema, es el reconocimiento, entre otros valores, del respeto por la dignidad del ser humano, el cual debe inspirar todas las actuaciones del Estado, y constituye razón de ser, principio y fin último de la organización estatal. Según ha señalado la Corte Constitucional, "el principio fundamental de la dignidad humana no sólo es una declaración ética sino una norma jurídica de carácter vinculante para todas las autoridades (C.P., art. $1^{\circ}$ )" (sentencia T499/92). Su consagración como valor fundante y constitutivo del orden jurídico "obedeció a la necesidad histórica de reaccionar contra la violencia, la arbitrariedad y la injusticia, en búsqueda de un nuevo consenso que comprometiera a todos los sectores sociales en la defensa y respeto de los derechos fundamentales" (sentencia T-499/92).

Con fundamento en lo anterior, el respeto a la dignidad humana debe inspirar todas las actuaciones del Estado en sus diversas manifestaciones. En consecuencia,

las autoridades están precisamente instituidas para proteger a toda persona en su vida, entendida en un sentido amplio como 'vida plena'. La integridad física, psíquica y espiritual, la salud, el mínimo de condiciones materiales necesarias para la existencia digna, son elementos constitutivos de una vida íntegra y presupuesto necesario para la autorrealización individual y social. Un Estado insensible a las necesidades de los ciudadanos, no se compadece con sus fines esenciales, sino que al contrario, cosifica al individuo y traiciona los valores fundamentales del Estado social de derecho (C.P., art. 1ํ / sentencia T-499/92). 
La dignidad de la persona es entendida como el punto de referencia que justifica y fundamenta la protección de todos los derechos fundamentales. Es claro cómo los derechos humanos, en tanto son expresión jurídica de la dignidad humana, están vinculados no sólo con todas las áreas del Derecho, sino con todos los campos de la actividad humana y de la convivencia social, en los que la dignidad del individuo pueda ser vulnerada o requiera de protección y tutela.

De otra parte, el principio de la responsabilidad del Estado se encuentra determinado a partir del artículo 6ำ de la Carta Política, cuando expresamente respecto de las autoridades públicas estipula que ellas son responsables por infringir la Constitución y las leyes y "por omisión o extralimitación en el ejercicio de sus funciones". Este artículo se encuentra en relación directa con el 124 constitucional, que le traslada al legislador la obligación de determinar el régimen para la responsabilidad de los servidores públicos y la manera de hacerla efectiva (Santofimio Gamboa, 2005: pp. 259-260).

Entretanto, el artículo 90 de la Constitución Política, en su inciso 1ํㅡ, establece que: "El Estado responderá patrimonialmente por los daños antijurídicos que le sean imputables, causados por la acción o la omisión de las autoridades públicas". De este modo, la norma citada de la Carta Fundamental consagró de manera expresa la responsabilidad del Estado, por hechos atribuibles a la administración pública, inclusive por actuaciones lícitas de las cuales se deriven hechos perjudiciales para los administrados, "como una ratificación de la autonomía del tema de la responsabilidad administrativa y de su sometimiento al derecho público, aunque ya no fundándose en el derecho francés sino más bien en el español" (Rodríguez R., 1995: p. 382), y sobre las bases de mayor garantía y seguridad jurídica para los particulares, no sólo de los ciudadanos colombianos, sino de cualquier persona que en territorio colombiano reciba un daño como consecuencia del funcionamiento de los servicios públicos, a ser reparado, a quedar indemne, a recibir la correspondiente indemnización de la administración causante del daño. 
Así las cosas, se observa que conforme a la letra del artículo 90 de la Carta Política, para que exista materialmente el concepto de responsabilidad patrimonial del Estado se requiere de la presencia articulada de tres claros elementos: la acción u omisión de unas autoridades, un daño o daños de carácter antijurídico, y una inevitable relación de causalidad entre la acción y la omisión de las autoridades públicas y los daños antijurídicos que generan obligaciones de carácter patrimonial para el Estado (Santofimio Gamboa, 2005: p. 95; Vidal Perdomo, Díaz Perilla \& Rodríguez, 2005: p. 95).

En este sentido, el elemento conceptual que por mandato constitucional configura la existencia del daño, y como consecuencia el de la indemnización de perjuicios, es a todas luces el denominado daño antijurídico. Si bien la Constitución Política no define como tal qué debe entenderse por daño antijurídico, la doctrina y la jurisprudencia se han encargado de predicar que existe daño antijurídico cuando se cause un detrimento patrimonial que carezca de título jurídico válido y que exceda el conjunto de las cargas que normalmente debe soportar el individuo en su vida social, recordando así que se desplaza el fundamento de la responsabilidad administrativa, del concepto subjetivo de la antijuridicidad de la acción del Estado al concepto objetivo de la antijuridicidad producido por ella.

Sin embargo, se excluye la imputabilidad en los casos de fuerza mayor, hecho de un tercero, culpa concurrente de la víctima, o cuando el perjuicio no se produce como consecuencia o con ocasión de una actividad de servicio público.

Adicionalmente, como criterio moralizador y de protección del patrimonio público, en los casos de dolo o culpa grave se impone para el Estado el deber de repetir contra el funcionario los perjuicios que haya sido condenado a pagar, sin pretender restringir la responsabilidad a aquellas personas vinculadas a la administración mediante un actocondición. 
Asimismo, el sistema de responsabilidad patrimonial del Estado es 'general', porque abarca todas las actividades administrativas imaginables, todas aquellas permitidas por el ordenamiento jurídico. Por tanto, en principio, la responsabilidad directa y objetiva de un ente público en Colombia, puede ser el fruto de actuaciones estrictamente materiales necesarias para la puesta en marcha de las obras públicas o de los servicios públicos, y puede ser fruto, también, no sólo de actuaciones positivas, sino de omisiones o inactividades, de situaciones dañosas debidas a la no actuación de una administración pública. Todos estos supuestos están recogidos en la fórmula genérica: funcionamiento de los servicios públicos, y en la jurisprudencia del Consejo de Estado, donde pueden encontrarse numerosos casos de daños derivados de una u otra forma de actuación administrativa.

En definitiva, resulta claro que la actual Carta Política es una constitución con ansias de vida, que vio la luz en medio de serias confrontaciones políticas, económicas y sociales, y se constituyó en la culminación de un intento por lograr un consenso nacional, en torno a la idea de país con posibilidades de desarrollo. Por ello, la Carta Fundamental colombiana es activa, no obstante requerir de desarrollo legal, como es apenas obvio, por cuanto el constituyente dejó sentadas unas bases de principios que en buena medida han podido ser materializados, debido a su aplicación por parte de diversas corporaciones pertenecientes a las Ramas de Poder Público que protegen con ello no solamente la propia Constitución, sino los derechos fundamentales y sustanciales (Rojas, 2005: pp. 725 y ss.).

\subsection{MARCO LEGAL DE LA RESPONSABILIDAD PATRIMONIAL EXTRACONTRACTUAL DEL ESTADO}

El artículo 140 del Código de Procedimiento Administrativo y de lo Contenciosoadministrativo (Ley 1437 de 2011) que empezó a regir el 2 de julio de 2012 -al igual que su antecesor el artículo 86 del Código Contencioso-administrativo (decreto-ley 01 de 1984)-, establecen que mediante el ejercicio de la reparación directa, la persona interesada podrá demandar directamente la reparación del daño cuando la causa sea 
un hecho, una omisión, una operación administrativa o la ocupación temporal o permanente de un inmueble por causa de trabajos públicos o por cualquiera otra causa imputable a una entidad pública o a un particular que haya obrado siguiendo una expresa instrucción de la misma.

De este modo, el objeto de tal mecanismo judicial de defensa busca la declaratoria de responsabilidad extracontractual y la consecuente reparación del daño causado (C.E., sentencia del 16 de marzo de 2005). Ciertamente, la reparación directa descrita como medio de control en la Ley 1437 de 2011 -y como acción en el decreto-ley 01 de 1984-, es un mecanismo de naturaleza subjetiva, individual, temporal y desistible, a través de la cual la persona que se crea lesionada o afectada por un hecho, omisión, una operación administrativa o la ocupación temporal o permanente de un inmueble por causa de un trabajo público o por cualquier otra causa, podrá solicitar directamente ante la Jurisdicción de lo Contencioso-administrativo que se repare el daño causado y se le reconozcan las demás indemnizaciones que correspondan, esto es, sin reclamación previa a la Administración o mediando petición de nulidad, como en el caso de la nulidad y restablecimiento del derecho. Se trata de un típico mecanismo tendiente a indemnizar a las personas con ocasión de la responsabilidad extracontractual en que pudo incurrir el Estado, en razón de las actividades anteriormente indicadas, que excluyen de entrada el acto administrativo.

En definitiva, cualquier actuación de la administración pública, diferente al acto administrativo -que hubiere causado un daño-, habilitará a quien lo sufrió o a sus derechohabientes para iniciar un proceso y buscar la satisfacción de sus pretensiones indemnizatorias (Galindo Vacha, 2006: pp. 554-555).

\subsection{SISTEMAS DE IMPUTACIÓN DE RESPONSABILIDAD PATRIMONIAL EXTRACONTRACTUAL DEL ESTADO EN COLOMBIA}

En Colombia, tal y como acontece en la mayoría de los países, lo relacionado con la responsabilidad del Estado no ha surgido precisamente de una regulación positiva - 
orgánica, expresa, integral y concreta-, sino de la jurisprudencia, de las enseñanzas de la doctrina científica y de normas positivas dispersas y parciales.

En efecto, frente a esa situación nos hallamos con la organización jurisdiccional y la jurisprudencia de la justicia contencioso-administrativa, debido a que con el establecimiento de un tribunal última instancia de competencia bien definida, como lo es el Consejo de Estado, se ha podido por obra puramente jurisprudencial, crear todo un cuerpo armónico de principios que desarrollan la responsabilidad del Estado, por actuaciones administrativas lesivas al interés privado.

Ciertamente, con anterioridad a la expedición de la Constitución Política de 1991, el Consejo de Estado elaboró y desarrolló los fundamentos de varias teorías o regímenes que permitían sustentar, con base en el análisis del caso concreto, la responsabilidad estatal cuando devinieran actuaciones administrativas lesivas al interés privado. A partir de la expedición de la nueva Carta Política, todo debate sobre el particular se ha resuelto con fundamento en lo dispuesto en el artículo 90 de la misma, según el cual el Estado responderá patrimonialmente por los daños antijurídicos causados por la acción u omisión de las autoridades públicas, que les sean imputables (C.E., sentencias del 15 de marzo de 2001, 31 de mayo de 2007).

El Consejo de Estado ha sostenido mayoritariamente, influenciado sin duda por pronunciamientos de la Corte Constitucional (sentencias C-333/96, C-892/01), que en el citado artículo 90 superior caben todos los regímenes de responsabilidad elaborados antes de la Carta Fundamental de 1991. Por consiguiente, debe establecerse entonces, en cada caso, si existen los elementos previstos en esta disposición para que surja la responsabilidad.

De manera esencial los regímenes de responsabilidad del Estado se han congregado tradicionalmente en:
a) Régimen de Responsabilidad Subjetiva,
b) Régimen de Responsabilidad Objetiva. 


\subsubsection{Régimen de Responsabilidad Subjetiva del Estado}

De manera general se ha considerado por la jurisprudencia del Consejo de Estado, que las personas públicas son responsables cuando causan un daño como consecuencia de un actividad irregular, que constituye una falla en el servicio que prestan por causa de actuaciones administrativas, omisiones, hechos, operaciones o vías de hecho de la administración; es decir, que en principio la Administración sólo debe responder cuando se prueba alguna deficiencia en el desarrollo del servicio.

El concepto de falla del servicio como elemento estructural del sistema, no como el sistema de responsabilidad, ha sido clarificado por la doctrina y la jurisprudencia, en el sentido de concretarlo a las situaciones en las que el Estado, debiendo prestar un servicio no lo presta o lo hace con retardo, irregularidad o ineficiencia. Lo anterior supone la existencia de una obligación a cargo del Estado y la infracción de esa obligación. La esencia del asunto radica en determinar la existencia de dicha obligación a cargo del Estado, y el criterio de identificación del incumplimiento obligacional administrativo, debiéndose tener en cuenta que la regla general consiste en que estas obligaciones deben ser concretas, determinadas y especificadas por las leyes o los reglamentos, que consagran las funciones que a cada organismo administrativo le corresponde ejecutar (C.E., sentencias del 17 de febrero de 1994, 3 de noviembre de 1994, 13 de febrero de 1997, 24 de febrero de 2005, 11 de mayo de 2006, 6 de marzo de 2008, 25 de febrero de 2009; Ruíz Orejuela, 2010: p. 2; Vidal Perdomo, Díaz Perilla \& Rodríguez, 2005: pp. 105-107; Gil Botero, 2011: p. 316). Por consiguiente, si el ejercicio de la función no implica ninguna deficiencia o irregularidad, no habrá lugar a la responsabilidad (Rodríguez R., 1995: p. 383; Younes Moreno, 1994: pp. 250-252).

En términos generales, con respecto a la responsabilidad del Estado se ha considerado que "las personas públicas son responsables cuando causan un daño como consecuencia de una actividad irregular, que constituye una falla del servicio que prestan. Es decir, que en principio la administración solo debe responder cuando se prueba alguna deficiencia en el desarrollo del servicio" (Rodríguez R., 1995: p. 383); es decir, que "se tendrá en cuenta si la administración dentro de sus obligaciones no actuó 
cuando debía hacerlo, actuó pero de forma incorrecta o indebida, o lo hizo bien pero tardíamente" (Vidal Perdomo, Díaz Perilla \& Rodríguez, 2005: p. 94).

En los casos en los cuales es aplicable éste régimen de imputación, la responsabilidad surge a partir de la comprobación de la existencia de tres elementos fundamentales, los cuales deben ser probados adecuadamente en el proceso, a saber (C.E., sentencia del 11 de mayo de 2006).

1. El daño antijurídico sufrido por el interesado;

2. La falla del servicio propiamente dicha, que consiste en el deficiente funcionamiento del servicio, porque no funcionó cuando ha debido hacerlo, o lo hizo de manera tardía o equivocada; para su comprobación, el operador jurídico al hacer el control de la actividad estatal, debe efectuar una comparación entre la actividad desplegada por la Administración y la norma que consagra el deber jurídico, para así verificar la posible configuración de una falla del servicio;

3. Una relación de causalidad entre estos dos elementos, es decir, la comprobación de que el daño se produjo como consecuencia de la falla del servicio.

En estos eventos la entidad pública sólo puede exonerarse demostrando fuerza mayor o caso fortuito, hecho exclusivo y determinante de la víctima o de un tercero, pues en el fondo lo que acredita es que no hay relación de causalidad entre la falta o falla del servicio y el daño causado. Obviamente, habrá casos de concausalidad, bien entre la falla y la culpa de la víctima, entre la falla y el hecho de un tercero o aun entre la falla y la fuerza mayor o el caso fortuito, en los cuales la responsabilidad del Estado quedará limitada en la proporción en que su falta o falla sea reconocida como causa eficiente del daño sufrido, presentándose entonces la figura conocida en el derecho como "compensación de culpas" o repartición de responsabilidades (C.E., Sentencia del 28 de octubre de 1976). 
También se exonera el Estado, cuando el daño es causado por el agente administrativo, en actos fuera del servicio o sin conexión con él y cuando la causa del daño es la falta personal del agente, difícil de definir y de determinar doctrinaria y jurisprudencialmente, encontrándose, hasta ahora sólo ejemplos, como los de aquellos casos en que el agente actúa por motivos pasionales (C.E., Sentencia del 28 de octubre de 1976).

A decir verdad, la jurisprudencia del Consejo de Estado ha sido reiterativa en cuanto a que el artículo 90 de la Constitución Política consagró la falla del servicio como el régimen general de responsabilidad estatal, al lado del cual se reconoce la existencia de regímenes objetivos, lo cual permite indicar que bajo el fundamento del rompimiento de igualdad ante las cargas públicas, no pueden indemnizarse todos los daños que sufran los particulares, sin que exista un título de imputación que permita atribuírselos a determinada autoridad estatal (C.E., sentencias del 25 de febrero de 1993, 17 de febrero de 1994 y 3 de noviembre de 1994).

Omisión de la Administración: Absoluta ausencia de acción o de funcionamiento de la Entidades del Estado, en el cumplimiento de sus funciones legalmente encomendadas. Cuando de esa omisión en la prestación de un servicio, el cumplimiento de una obligación contenida en la Ley o en los reglamentos, resultan daños por la negligencia injustificada. (Ruiz Orejuela, 2010: p. 4).

- Omisiones Laxas: Es la negligencia u olvido en los deberes de cuidado, pudiendo evitar un daño previsible.

- Omisiones en sentido estricto: El incumplimiento de un deber legal previamente establecido, y que el Estado está en la obligación de ejecutar.

- Las omisiones legislativas: Hacen referencia a la inactividad del legislador o el incumplimiento por parte de este último de su deber de legislar expresamente señalado en la Constitución, las omisiones legislativas pueden ser de dos clases: absolutas o relativas.

- La omisión legislativa absoluta: Hace referencia al incumplimiento por parte del legislador el deber contenido en la Constitución Nacional para expedir las 
regulaciones específicas, es decir que el legislador guarda una total pasividad inactividad se abstiene de expedir la norma incumpliendo el mandato Constitucional y, por ende, supone la ausencia total de un texto o precepto legal.

- La omisión legislativa relativa: El legislador realiza su actividad de regulación pero lo hace de manera defectuosa, incompleta, "dado que al regular una situación determinada, éste no tiene en cuenta, omite, o deja de lado, supuestos de hecho que, al momento de aplicarse el precepto correspondiente, genera tratamientos inequitativos o el desconocimiento de derechos de los destinatarios de la norma respectiva (v. gr. derecho a la igualdad, derecho al debido proceso o del derecho de defensa, derechos adquiridos, etc)" lo cual se nota en la aplicación práctica de la norma, toda vez que genera tratamiento inequitativo entre los destinatarios, o puede desconocer en algunos de ellos sus derechos. (Ruiz Orejuela, 2010: p. 199).

\subsubsection{Responsabilidad por presunta falla del servicio}

La jurisprudencia del Consejo de Estado, dentro de un proceso de ampliación del régimen de responsabilidad del Estado en Colombia, ha aplicado la figura denominada "falla del servicio presunta", como un régimen intermedio entre el puramente subjetivo y los de responsabilidad puramente objetiva (Rodríguez R., 1995: p. 386).

En este régimen de imputación, se entiende que la responsabilidad sigue organizada sobre la noción de falla o falta en el servicio, como en el evento de la falla en el servicio ordinaria, con la única diferencia de que el actor no tendrá que demostrar la conducta omisiva o irregular de la administración porque ésta se presume.

Así las cosas, se presume la culpa y, por tanto, quien tiene que demostrar la no ocurrencia de la falta o falla será la entidad pública que ocasionó el daño, es decir, tendrá que probar que su actuar se enmarcó dentro del ámbito de la prudencia, diligencia y la pericia, y que el daño ocurrió por causas ajenas a su actuar, o sea que devino por fuerza mayor, culpa exclusiva de la víctima o el hecho de un tercero, para 
quebrar la relación de causalidad (C.E., sentencias del 30 de julio de 1992, 24 de agosto de 1992).

Ahora bien, la jurisprudencia contencioso-administrativa colombiana ha sido enfática en afirmar que la falla presunta del servicio no debe asimilarse con el principio de la carga dinámica de la prueba, puesto que éste

\begin{abstract}
se presenta como una excepción a la regla general, según la cual quien alega prueba; la excepción que este principio consagra consiste precisamente en que el deber de probar un determinado hecho o circunstancia se impone a la parte que se encuentre en mejores condiciones de hacerlo, aun cuando no lo haya alegado o invocado. Este principio se plantea como una solución para aquellos casos en los que el esclarecimiento de los hechos depende del conocimiento de aspectos técnicos o científicos muy puntuales que sólo una de las partes tiene el privilegio de manejar. En síntesis, la aplicación del principio de la carga dinámica está condicionada al criterio del juez y supone la inversión de la carga de la prueba para un caso concreto. Por su parte, la falla presunta del servicio exime a la parte actora de la prueba de la falla del servicio, pues ésta se presume; en estos casos corresponde a la entidad demandada desvirtuar dicha presunción, lo cual permite afirmar, contrario a lo que sucede en tratándose de la aplicación del principio de la carga dinámica de la prueba, que la inversión del deber probatorio se presenta como consecuencia necesaria de la aplicación de dicho régimen (C.E., sentencia del 3 de mayo de 2001).
\end{abstract}

\title{
2.3.1.2. Responsabilidad por falla anónima del servicio
}

Según ha sostenido el Consejo de Estado (sentencias del 28 de noviembre de 2002, 14 de marzo de 2002, 25 de febrero de 2009), la falla del servicio es 'anónima', en aquellas situaciones en que no se requiere que exista certeza sobre la identidad del servidor público, autor material del daño causado; sin embargo, esto no significa que no deban demostrarse los hechos a partir de los cuales se pretende imputarle al Estado ese daño para que haya lugar a condenarle patrimonialmente.

\subsubsection{Régimen objetivo de responsabilidad del Estado}

A partir de la expedición de la Constitución Política de 1991, todo debate sobre la responsabilidad del Estado debe resolverse con fundamento en lo dispuesto en el artículo 90 de la misma. De conformidad con lo preceptuado en dicho precepto superior, el Estado debe responder “(...) patrimonialmente por los daños antijurídicos que le sean imputables, causados por la acción o la omisión de las autoridades públicas". Dentro de este marco constitucional, no existe duda de que el fundamento de la responsabilidad administrativa no siempre estriba en una conducta dolosa o culpable -que deba ser sancionada-, sino por el quebranto patrimonial que hay que reparar. 
Así las cosas, en materia de responsabilidad estatal la atención del constituyente se desplazó desde el autor o la conducta causante del daño, hacia la víctima misma. Por ello, importa más reparar el daño causado, que castigar una acción u omisión administrativa culpable. La finalidad de la responsabilidad patrimonial no consiste, pues, en borrar una culpa, sino en hacer recaer sobre el patrimonio de la Administración el daño sufrido por el particular (C.E., sentencia del 22 de noviembre de 1991).

No hay duda de que a partir del texto constitucional citado, la responsabilidad del Estado se ha tornado en grado sumo objetiva, puesto que la falta o falla del servicio ha dejado de ser el fundamento único del sistema indemnizatorio, convirtiéndose simplemente en uno de los criterios jurídicos de imputación de daños a la Administración. Por ello es posible, en muchos casos, que se tenga derecho a la indemnización de los daños patrimoniales ocasionados con una actuación administrativa lícita. La filosofía que informa todo este universo jurídico se apoya en el principio de solidaridad, que se recoge también en el artículo primero de la Carta Fundamental de 1991, cuando se afirma que Colombia es un Estado social de Derecho, fundado en el respeto de la dignidad de la persona humana y en la solidaridad de las personas que la integran (C.E., sentencia del 22 de noviembre de 1991).

Sin embargo, con antelación a la expedición de la Constitución Política de 1991, la jurisprudencia del Consejo de Estado elaboró y desarrolló paulatinamente los fundamentos de varias teorías o regímenes que permitían sustentar, con base en el análisis del caso concreto, la responsabilidad del Estado basado en la no exigencia de la culpa o falla en el servicio. Ciertamente, la jurisprudencia contencioso-administrativa colombiana (sentencias del 20 de febrero de 1989, 28 de abril de 1989, 31 de julio de 1989, 24 de octubre de 1990), comenzó a explorar una serie de regímenes diferentes que establecieran una reparación de los daños cometidos por las autoridades públicas en forma diligente, sin mediación de una falla en el servicio, o sea, sin depender del elemento subjetivo de responsabilidad, teniendo en cuenta el crecimiento desmesurado 
de las actividades del Estado, la evolución vertiginosa de la tecnología y la dificultad para las víctimas de ciertos daños de reconstruir los hechos en el momento de demostrar un daño (Retis Amaya, 2005: p. 3).

El régimen objetivo de 'responsabilidad' constituyó un gran avance en materia de responsabilidad del Estado, al aceptar que la misma se compromete también cuando, independientemente de que la actuación haya sido irregular o no, ésta produzca un daño a alguien que no tenía la carga de soportarlo. Además, debe establecerse, en cada caso, si existen los elementos previstos para que surja la responsabilidad. No obstante, esto no quiere significar que la responsabilidad por falla haya quedado en el olvido, puesto que sigue erigiéndose como la regla de responsabilidad general.

Pues bien, la responsabilidad objetiva permite considerar no sólo nuevos sistemas de imputación de responsabilidad de las autoridades públicas, sino que éstos podían serlo de responsabilidad sin falta, responsabilidad objetiva en la que el Estado limitaba su actuación a lo legítimamente concebido en las leyes y reglamentos, pero, sin embargo, sin que pudieran ignorarse los perjuicios causados a los particulares de forma excepcional, sin que debieran tolerarlo como un daño común o carga colectiva (Ruiz Orejuela, 2010: p. 17).

En este orden de ideas, se tiene que en algunos casos no se exige la presencia de una falla del servicio para deprecar la responsabilidad del Estado, es decir, no aparece en ninguna forma el concepto de culpa, por lo cual se tratará de responsabilidad objetiva (Rodríguez R., 1995: p. 383). Así sucede con la actuación administrativa legal, aquella que se sujetó a los parámetros constitucionales y/o de legalidad, pero que le causó daño a una persona, como podría ser, entre otras, la responsabilidad por el riesgo excepcional, o por el rompimiento de la igualdad de las cargas públicas (daño especial), o la responsabilidad por trabajos públicos, o la responsabilidad por expropiación u ocupación de inmuebles en caso de guerra (Galindo Vacha, 2006: p. 555; Rodríguez R., 1995: p. 383). 


\subsubsection{Régimen de responsabilidad del Estado por el riesgo excepcional} Una modalidad de la responsabilidad objetiva del Estado, es decir, que no exige culpa o falla en el servicio, es la llamada responsabilidad por el riesgo excepcional. La jurisprudencia del Consejo de Estado ha enseñado magistralmente este régimen de responsabilidad, señalando que "en los eventos en que el daño es producido por las cosas o actividades peligrosas (armas de dotación oficial, vehículos automotores, conducción de energía eléctrica, etc.), el régimen aplicable es de carácter objetivo, porque el factor de imputación es el riesgo grave y anormal a que el Estado expone a los administrados. De tal manera que basta la realización del riesgo creado por la administración para que el daño resulte imputable a ella" (sentencia del 20 de febrero de 1989).

Inicialmente, este régimen empezó a reconocerse como un riesgo excepcional, únicamente para los daños causados por la conducción de energía eléctrica, considerándose la prestación del servicio de energía eléctrica como una actividad peligrosa en la cual se crea un riesgo excepcional, supuesto de responsabilidad objetiva (C.E. sentencias del 2 de febrero de 1984, 8 de marzo de 1984, 20 de febrero de 1989, 9 de junio de 2005, 6 de julio de 2005), advirtiéndose que cuando a pesar de haber prestado el servicio de energía con diligencia y cuidado, se creó un riesgo excepcional y que, por lo tanto, el afectado tiene derecho a indemnización. Posteriormente, este régimen de responsabilidad comenzó progresivamente a extenderse a todos los casos en que la actividad del Estado se catalogaba de peligrosa, verbigracia: la utilización de armas de fuego o explosivos (C.E., sentencias del 15 de marzo de 2001, 14 de junio de 2001, 24 de junio de 2006, 30 de noviembre de 2006, 7 de marzo de 2007, 8 de marzo de 2007), la conducción de naves, aeronaves y de vehículos automotores (C.E., sentencias del 27 de julio de 2000, 9 de agosto de 2001, 5 de diciembre de 2005, 1o de marzo de 2006, 11 de mayo de 2006, 31 de agosto de 2006), etc. 
A nivel doctrinario (Galindo Vacha, 2006: p. 555; Rodríguez R., 1995: p. 384; Retis Amaya, 2005: pp. 5 y ss.; Vidal Perdomo, Díaz Perilla \& Rodríguez, 2005: p. 94; Younes Moreno, 1994: pp. 252-254) y jurisprudencial (C.E., sentencias del 2 de febrero de 1984, 8 de marzo de 1984, 20 de febrero de 1989, 21 de octubre de 1999), se ha entendido este régimen como fundamento de responsabilidad en cabeza del Estado, cuando quiera que éste compromete su responsabilidad en la construcción de una obra o la prestación de un servicio público, desarrollados en beneficio de la comunidad, con la utilización de medios o recursos técnicos que colocan a las personas o a sus patrimonios en situación de quedar expuestos a sufrir un

"riesgo de naturaleza excepcional que, dada su particular gravedad, excede notoriamente las cargas que normalmente han de soportar los administrados como contrapartida de los beneficios y ventajas que resultan de la ejecución de la obra o de la prestación del servicio público" (C.E., sentencia del 20 de febrero de 1989).

No se trata, en consecuencia, de un régimen de falla del servicio probada, ni de falla presunta, en el que el Estado podría exonerarse demostrando que actuó en forma prudente y diligente. Al actor le bastará probar la existencia del daño y la relación de causalidad entre éste y el hecho de la administración, realizado en desarrollo de la actividad riesgosa.

En efecto, el demandante no tendrá que demostrar, como en el régimen de falla probada, la calificación de la conducta subjetiva de la administración; le bastará demostrar la ocurrencia del hecho. Por lo tanto, de nada le servirá a la administración demostrar diligencia y cuidado, o sea, la ausencia de falla; para exonerarse, deberá probar la existencia de una causa extraña, que rompa el nexo de causalidad entre el hecho o la omisión y el daño ocasionado, esto es, fuerza mayor, hecho exclusivo de un tercero o culpa exclusiva de la víctima. En cuanto al daño, el promotor del juicio también tendrá que representarle al juez la existencia de un menoscabo que reúna las siguientes cualidades: cierto, particular y que recaiga sobre una situación o de acto o de hecho que esté protegida jurídicamente. En cuanto al nexo de causalidad, el actor igualmente tendrá que demostrar, mediante prueba directa o indirecta, que el daño es consecuencia eficiente y determinante de la conducta del Estado. $\mathrm{Y}$ debe probar ese nexo por qué la ley no ha señalado en materia de relación causal ni presunciones 
legales, respecto de las cuales ha probado un hecho el legislador que infiera la causalidad adecuada, ni tampoco los conocimientos del juez sobre la realidad social lo autorizan para deducir con certeza el adecuado nexo de causalidad (C.E., sentencias del 21 de octubre de 1999, 15 de marzo de 2001, 14 de junio de 2001, 8 de agosto de 2002, 10 de julio de 2003, 10 de agosto de 2005, 2 de mayo de 2007).

En definitiva, las condiciones requeridas bajo el concepto de la estructuración de la responsabilidad por riego excepcional son:

- En desarrollo de una obra o actividad de servicio público, la administración emplea recursos o medios que coloquen a los administrados o a sus bienes en una situación de quedar expuestos a un riesgo, que dada su gravedad excede las cargas que normalmente deben soportar los ciudadanos, como contrapartida de las ventajas que reportan de la actividad o servicio.

- Si el riesgo así creado por la administración se realiza, esto es, se materializa, se produce un daño indemnizable.

- Conlleva por lo general el ejercicio de actividades peligrosas, como son la conducción de redes de energía eléctrica, manejo y transporte de explosivos, uso de armas de fuego y conducción de vehículos automotores o aeronaves, etc.

\subsubsection{Régimen de responsabilidad del Estado por el daño especial}

En cualquier actuación del Estado en que hubiere causado un daño, diferente al acto administrativo, habilitará a quien lo sufrió o a sus derechohabientes para iniciar un proceso y buscar la satisfacción de sus pretensiones indemnizatorias. Dentro de estas otras causas podría incluirse la actuación administrativa legal, aquella que se sujetó a los parámetros constitucionales y/o de legalidad, pero que le causó daño a una persona, como podría ser el rompimiento de la igualdad de las cargas públicas (daño especial / Cf. Galindo Vacha, 2006: pp. 554-555). 
La teoría del daño especial, última evolución de la jurisprudencia contenciosoadministrativa en Colombia ${ }^{3}$, con fuerte basamento en la equidad, la igualdad y la solidaridad, se enmarca dentro de los factores objetivos con los que se ha enriquecido el catálogo de títulos de imputación al Estado. ${ }^{4}$

En efecto, en el daño especial como título de imputación de la responsabilidad del Estado, "se parte de un principio básico del derecho moderno, cual es la igualdad de los ciudadanos frente a las cargas públicas" (Ruiz Orejuela, 2010: p. 17). De manera que la igualdad de los ciudadanos ante las cargas públicas obliga a la Administración a indemnizar como materialización del reequilibrio ante una ruptura de la mencionada igualdad, cuando ocasione una carga especial o un perjuicio determinado a un administrado.

En este orden de ideas, este sistema de imputación de responsabilidad extracontractual del Estado, tiene su epicentro en el daño especial y anormal sufrido por la víctima, la cual debe ser preservada frente al perjuicio no buscado, no querido, ni tampoco merecido (García de Enterría \& Fernández, 1983: p. 369). Sin embargo, es necesario entender, ante todo, que el daño especial es un resultado colateral, residual de una actuación de la Administración orientada a cumplir su misión del servicio público, que se traduce en un daño que pone en una situación de desequilibrio ante las cargas públicas a la víctima o víctimas del mismo (C.E., sentencias del 28 de abril de 2005, 11 de febrero de 2009).

${ }^{3}$ El Consejo de Estado ha construido una ingente línea jurisprudencial respecto del daño especial, siendo utilizada por primera vez en 1947, oportunidad en la que expuso:

\begin{abstract}
"Consecuencia recta de la anterior proposición, en razón pura, es la de que la operación administrativa ni los hechos que la constituyen, podrán jamás ser generadores de violación alguna, pero sí, en cambio, causar lesiones patrimoniales o, en su caso, daños especiales, no por involuntarios o producto de la necesidad de obrar en un momento dado, menos dignos de resarcimiento, que es lo que la ley colombiana ha querido, a diferencia de otras legislaciones que sólo conceden acción cuando el perjuicio proviene de una vía de hecho" (sentencia del 27 de julio de 1947: pp. 448 y ss.).
\end{abstract}

${ }^{4}$ De acuerdo con Vázquez Ferreyra, "Ios factores objetivos de atribución constituyen un catálogo abierto sujeto a la expansión. Por ello la mención sólo puede ser enunciativa. Al principio sólo se mencionaba el riesgo creado; un análisis posterior desprendido del perjuicio subjetivista permitió vislumbrar a la equidad y la garantía. Hoy conocemos también otros factores, como la igualdad ante las cargas públicas, que es de creación netamente jurisprudencial" (1993: p. 197). 
En este sentido, el Consejo de Estado ha indicado que "se compromete la responsabilidad patrimonial de la administración pública cuando ésta, en ejercicio de sus competencias y obrando dentro del marco de las disposiciones legales, causa con su actuación un perjuicio de naturaleza especial y anormal a un administrado, un daño que excede el sacrificio que el común de los ciudadanos debe normalmente soportar en razón de la peculiar naturaleza de los poderes públicos y de la actuación estatal" (sentencia del $1^{\circ}$ de agosto de 1991).

Ahora bien, el daño especial ha sido entendido como un título de imputación que se aplica de manera excepcional y por equidad, justamente porque es subsidiaria, de modo, que parte de la imposibilidad de reparar un daño palmariamente antijurídico con fundamento en un régimen subjetivo de responsabilidad, y ha de recurrirse a ella tan sólo en eventos en los que el caso concreto examinado no logre su encasillamiento dentro de los otros regímenes de responsabilidad y se aprecie por el sentenciador que esa ausencia de calificación comporta vulneración injustificada del principio de equidad (C.E., sentencias del 20 de febrero de 1989, 11 de febrero de 2009).

En este régimen de imputación de la responsabilidad extracontractual del Estado se enmarcan, entre otros, supuestos tales como -por ejemplo-, el de daños sufridos por conscriptos en desarrollo del servicio militar obligatorio (C.E., sentencia del $1^{\circ}=\mathrm{de}$ agosto de 2005), el hecho del legislador -ley conforme a la Constitución- que genera imposibilidad de accionar ante un daño antijurídico, la construcción de obras públicas que disminuyen el valor de los inmuebles aledaños (C.E., sentencia del 13 de diciembre de 2005), las víctimas civiles del enfrentamientos entre el ejército y la guerrilla (C.E., sentencias del 24 de abril de 1991, 17 de junio de 1993).

Tanto en la doctrina como en la jurisprudencia ha existido una gran confusión entre el daño especial y el riesgo excepcional, en principio, porque los dos regímenes se fundamentan en el principio de igualdad de las personas frente a las cargas públicas y debido a que ambos han invocado, para su existencia, razones de equidad, sin detenerse a analizar que la actividad legítima del Estado causante del daño puede ser 
riesgosa o no. En el régimen del riesgo excepcional, el título de la imputación del daño es el 'riesgo', de manera que el daño sufrido deviene de la actividad riesgosa; entretanto, el daño especial será directamente la ruptura del principio de igualdad frente a las cargas públicas, de modo que la antijuridicidad del daño dependerá exclusivamente de tal desequilibrio y deberá poseer las características de anormalidad y especialidad (C.E., sentencias del 24 de abril de 1991, 23 de octubre de 2003).

Por último, es relevante resaltar que el Estado no será responsable, aunque cause un daño especial en los anteriores términos, cuando el interés lesionado no sea legítimo, o sea contrario al orden público, a la moral o a las buenas costumbres, aun si dicho interés no estaba expresamente prohibido antes o en el momento del hecho dañoso.

\subsubsection{Régimen de responsabilidad del Estado por ocupación de inmuebles por trabajos públicos}

La ocupación de inmuebles por trabajos públicos corresponde a la especie de la responsabilidad objetiva, y se configura probando que una parte o la totalidad de un bien inmueble de propiedad del demandante fue ocupado permanentemente por la administración o por particulares que actúan autorizados por ella (C.E., sentencias del 10 de mayo de 2001, 10 de agosto de 2005).

La jurisprudencia contencioso-administrativa colombiana (C.E., sentencias del 10 de mayo de 2001, 10 de agosto de 2005) ha señalado como elementos de la responsabilidad del Estado por ocupación permanente por trabajos públicos los siguientes:

1. El daño antijurídico, que consiste en la lesión al derecho real de propiedad de que es titular el demandante, quien no tiene el deber jurídico de soportarla.

2. La imputación del daño al ente público, por la ocupación permanente, total o parcial del bien inmueble de propiedad de la demandante. 
La jurisprudencia (C.E., sentencias del 10 de mayo de 2001, 10 de agosto de 2005) y la doctrina (Rodríguez R., 1995: p. 385) han entendido que en este caso basta que se demuestre el derecho de dominio sobre el bien y los daños ocasionados como consecuencia de las órdenes y providencias administrativas.

El Estado, por su parte, sólo podrá exonerarse de responsabilidad, si desvirtúa la relación causal mediante la prueba de una causa extraña tal como la fuerza mayor, el hecho exclusivo de tercero o el hecho exclusivo de la víctima (C.E., sentencias del 10 de mayo de 2001, 10 de agosto de 2005).

\subsection{REFLEXIÓN}

Aun cuando la Constitución Política de 1991 no ha venido a crear en Colombia el instituto de la responsabilidad estatal, puesto que la existencia de un sistema de responsabilidad del Estado fue aplicado y desarrollado por la jurisprudencia del Consejo de Estado bajo la vigencia de la Constitución Nacional de 1886.

Empero, no puede dejarse de lado que el actual texto político ha dado un paso firme en la consolidación y en la constitucionalización de la responsabilidad patrimonial del Estado en nuestro país, lo cual ha hecho a través de un conjunto de normas de mayor rigor técnico, amplias y diáfanas, como el Preámbulo y los artículos 1, 2, 4, 6, 13, 90 y 95 superiores. 


\section{LA RESPONSABILIDAD DEL ESTADO LEGISLADOR}

\subsection{EL RECONOCIMIENTO DE LA RESPONSABILIDAD DEL ESTADO LEGISLADOR}

En forma general se ha aceptado que la responsabilidad del Estado puede devenir contractual o extracontractualmente; a su turno, esta última puede provenir de hechos o actos de cualquier órgano del Estado, mediante los cuales se manifiesten sus poderes (administrativo, judicial o legislativo).

Con respecto a la responsabilidad del Estado Legislador, debe indicarse que dicha teoría es relativamente reciente y no ha sido un asunto pacífico. En efecto, durante muchos años -tradicionalmente-, tanto en Colombia como en el Derecho Comparado se sostuvo como dogma irrefutable la teoría de la irresponsabilidad del Estado en razón de su actividad legislativa. Así, por ejemplo, el tratadista francés Michoud llegó a aseverar que "la cuestión de la responsabilidad por falta no se puede plantear en relación con los actos del poder legislativo. Puede decirse, en verdad, que el legislador no comete falta en sentido jurídico del término, porque su derecho no tiene límite de orden constitucional o legal" (Sayagués Laso, 1963: pp. 594-595).

Tal tesis encontró fundamento, en primer lugar, en la soberanía del poder legislativo, puesto que se entiende que la Ley provenía directamente de los representantes de los ciudadanos y beneficia a todos, por lo que éstos deben soportarla sin poder obtener compensación alguna por el eventual sacrificio o daño que aquélla pueda ocasionar. En lo pertinente, Laferrière señaló:

Es de principio que a los particulares -por medidas legislativas- no les confieren ningún derecho de indemnización. La Ley es, en efecto, un acto de soberanía, y lo propio de la soberanía es imponerse a todos, sin que pueda reclamar de ella ninguna compensación. El legislador sólo puede apreciar, teniendo en cuenta la naturaleza y la gravedad del daño, en consonancia con las necesidades y los recursos del Estado, si debe acordar esta compensación: las jurisdicciones no pueden situarse en su lugar, no pueden más que evaluar el montante teniendo en cuenta las bases y la Ley (Torregoza Sánchez, 2007: pp. 14-15). 
Al respecto, el ilustre profesor Léon Duguit sostuvo en la primera edición de su Tratado de Derecho Constitucional:

Es evidente que tomadas en sí las dos nociones de responsabilidad y de soberanía son antinómicas porque si el Estado se considera soberano, no puede admitirse que sea responsable, y si se afirma que es responsable, no puede admitirse que sea soberano. O la soberanía es nada, o ella es, como se ha dicho, ese rasgo de voluntad que no se determina sino por sí misma, es decir, que no puede estar limitada por un elemento extraño, ni sometida a obligaciones sino en la medida consentida. De ahí resulta que una persona soberana no puede ser responsable de sus actos; esto es lo menos, no puede serlo sino en la medida en que lo quiera. Pero entonces no se trata ya de una responsabilidad porque no es una obligación (Garrido Falla, 1989: p. 37).

En segundo término, la tesis aludida se basa en el carácter esencialmente general y abstracto de la Ley, que impide que se concrete la especialidad del daño, como requisito 'sine qua non' para que se configure el derecho a una reparación; de manera que los daños irrogados por la actividad del legislador constituyen 'cargas públicas' que deben soportar los coasociados como una consecuencia propia del hecho de vivir en sociedad, llegándose a sostener que la Ley "causante de perjuicios era expresión de la voluntad general y por consiguiente también de la voluntad de los que sufren el daño" (Marienhoff, Miguel S., 1987: p. 600).

En tercera medida, se argumentó que para que se pueda reconocer la responsabilidad del Estado Legislador, imperiosamente, debe ser la misma Ley la que prevea la correspondiente indemnización, debido a que en el evento de que el legislador hubiese guardado silencio sobre el particular, debe ser comprendido dicho silencio como expresión de la voluntad implícita de excluir la responsabilidad, puesto que de lo contrario el juez sustituiría al legislador (Torregoza Sánchez, 2007: p. 15).

En cuarto lugar, la tesis bajo descripción se soporta en la paralización de la evolución legislativa, puesto que al respecto exponía Maurer:

El ciudadano no puede confiar en que las leyes dadas en un tiempo vayan a permanecer incambiadas. Menos aún puede pretender que el legislador actúe de una determinada manera (...) El legislador tiene que estar abierto hacia el futuro, y tener la posibilidad de reaccionar sobre nuevos desarrollos y evoluciones; admitir nuevos conocimientos e imponer nuevas concepciones políticas, como también corregir en el futuro viejos errores (García de Enterría, 2007: pp. 34-36). 
De esta manera, Quintana López sostiene que el reconocimiento del derecho de los administrados al resarcimiento de los daños causados por el Estado Legislador, debe estar rodeado de cautelas, pues de lo contrario el legislador perdería operatividad, con el consiguiente anquilosamiento del ordenamiento jurídico, situación abiertamente incompatible con la esencia misma del Estado Social de Derecho, para lo cual debe conjurarse el peligro de la petrificación normativa, una de cuyas manifestaciones sería vincular la evolución del ordenamiento a la satisfacción sistemática de indemnizaciones, con lo cual el legislador perdería la capital posición que ocupa en nuestro Estado Social y Democrático, y con ello quedaría igualmente incumplido el mandato progresivo que impone el texto constitucional (Quintana López, 1994: pp. 103 y ss.).

Sin embargo, la teoría de la 'injusticiabilidad' del poder legislativo comenzó a relativizarse, y dicha "tesis está en la actualidad completamente abandonada" (Penagos, 1997: p. 236). De este modo, el destacado tratadista uruguayo Sayagués Laso advertía -a mediados del siglo XX- cómo

la responsabilidad del Estado por acto legislativo es la que en el derecho público surge cronológicamente en último término, al punto que en muchos países todavía no ha logrado afirmarse ni en la doctrina ni en la jurisprudencia. No obstante, se nota una acentuada tendencia favorable, que cabe esperar se generalice por ser la que más se ajusta a los principios de justicia y equidad (Sayagués Laso, 1963: pp. 593-594).

Así, por ejemplo, se destaca cómo el ilustre profesor León Duguit, quien actuara como tenaz defensor del principio de soberanía como base de irresponsabilidad del Estado Legislador, al modificar su posición inicial contribuyó notoriamente a la desmitificación de la idea de la soberanía estatal, al formular una teoría de la responsabilidad del Estado por el hecho del legislador en la segunda edición de su "Traité de droit constituionnel", en la que señala: "el Estado es asegurador frente a los administrados de todos los riesgos que resulten de su actividad general, acaso no debe admitirse que ese seguro cubre incluso el riesgo resultante de la aplicación de una ley" (Sayagués Laso, 1963: pp. 595). De esta manera Duguit admite que ese seguro cubre también el riesgo que se genera por la aplicación de las leyes. 
Adicionalmente, el relevante jurista francés expone:

Suponiendo el caso de una ley cuya aplicación entrañe un perjuicio para uno o muchos individuos, ¿puede el Estado ser declarado responsable frente a ellos? No, con seguridad, si el Estado legislador es soberano. Pero si, como creo haberlo demostrado, la noción de soberanía es irreal y caduca, y si, por otra parte, en las concepciones jurídicas actuales el Estado se configura por los administrados como un asegurador de todo riesgo que deriva de su actividad general, ¿no debe concluirse que este seguro cubre igualmente el riesgo resultante de la aplicación de una ley, ya que, en definitiva, toda ley tiene por finalidad crear un servicio público o regular su funcionamiento? (C.E., sentencias del 28 de agosto de 1998).

Así las cosas, paulatinamente se va aceptando que la soberanía no reside en el Poder Legislativo, sino en el pueblo (art. 3 de la Constitución Política de Colombia), que es el 'constituyente primario'. El legislador es meramente el titular de una de las funciones radicadas en cabeza del Estado y, como tal, debe sujetarse, al igual que los demás poderes públicos, a los mandatos constitucionales (Díez, 1971, T. II: p. 141). En consecuencia,

es claro que cuando el Estado dicta una ley, debe hacerlo de conformidad con los preceptos constitucionales y respetando las garantías y derechos que la propia Constitución asegura a todas las personas. En caso contrario, el perjuicio sufrido por los particulares debe ser reparado. Ésta es una de las formas de establecer el imperio del derecho (García Mendoza, 1997: p. 21).

Ahora bien, resulta inaceptable considerar que todas las cargas que la Ley impone derivan en consecuencias propias del hecho de vivir en sociedad y que, al gravar a todas las personas por igual, el legislador no efectúa nada diferente a concretar el principio de igualdad de los administrados frente a las cargas públicas (Hoyos Duque, 1984: p. 33), puesto que en la práctica existen grupos de individuos que terminan soportando gravámenes más elevados en virtud de la utilidad general, lo cual jamás puede ser desconocido por el Estado, con respecto al derecho indemnizatorio que les asiste en virtud del daño que se les ha ocasionado (Torregoza Sánchez, 2007: pp. 2021).

Asimismo, tampoco es admisible considerar el argumento de la paralización de la evolución legislativa, debido a que si bien el ordenamiento jurídico de un país debe ajustarse a las circunstancias fácticas cambiantes día tras día, ello no debe hacerse a 
costa del sacrificio de los derechos de algunos coasociados (Torregoza Sánchez, 2007: p. 21).

De este modo, si bien es cierto que la Ley es la más sólida base de la organización del Estado de Derecho y de funcionamiento, no es menos cierto que la Ley puede ocasionalmente irrogar daños a los derechos e intereses de los particulares; sin embargo, no resulta desde ningún punto de vista que una Ley cause arbitrariedades.

En este orden de ideas, a comienzos del siglo XX, en contra del tradicional reducto de la inmunidad del Estado Legislador, se va imponiendo el principio de garantía patrimonial de los ciudadanos, primero frente a la expropiación y más lentamente frente a otros daños de naturaleza no expropiatoria, los perjuicios derivados de los actos del Poder legislativo -heredero de la inviolabilidad regia, ahora manifestación de la voluntad nacional-, como también se mantienen al margen de la misma e inabordables a cualquier pretensión de indemnización. Pese a ello, la indiscutible escala hacia la reducción de los ámbitos del poder exentos de control judicial no hace esperar el enfrentamiento con el tema que se plantea decididamente en Francia, de la mano de la jurisprudencia y la doctrina (Santamaría Pastor, 1972: pp. 57-136).

Al respecto, el destacado jurista y tratadista Georges Vedel ha recalcado:

El supuesto que corresponde por excelencia a la noción de la responsabilidad del Estado Legislador, es aquel en que una ley causa directamente perjuicio a los particulares sin que intervengan medidas de aplicación adoptadas por la administración. Así es, por ejemplo, cuando una ley prohíbe una actividad anteriormente lícita. ¿En qué medida pueden los particulares así lesionados obtener reparación? (1980: pp. 342 y ss.).

Del mismo modo, Marienhoff indica:

Si una 'ley' causa un perjuicio 'general' -y no meramente particular--, y tal ley resulta en oposición o en violación de una declaración, garantía o derecho constitucional, dicha ley debe declararse inconstitucional o debe admitirse la responsabilidad del Estado por el perjuicio o daño que a raíz de ella se ocasiona en el patrimonio de los administrados (1987: p. 724, §1646).

Respecto de la doctrina, es posible sostener que en la materia aún se encuentra dividida. Bielsa (1938: p. 538) niega tajantemente la posibilidad de responsabilizar patrimonialmente al Estado por actos del legislador, entre otros motivos porque sería 
imposible que éste cometiera actos antijurídicos o arbitrariedades. De hecho, para el destacado administrativista argentino, el instituto jurídico apto para las afectaciones o privaciones al dominio sería la expropiación, sólo en los casos pertinentes en que se pueda verificar la transmisión de propiedad al patrimonio público.

En el mismo sentido, se expresan las doctrinas que Jiménez Lechuga caracteriza como las teorías negativas de la responsabilidad patrimonial del Estado Legislador, las cuales -de manera general- indican:

Si el poder constituyente hubiese querido responsabilizar al poder legislativo ordinario por hechos o actos derivados de la aplicación de las leyes, hubiese debido incorporar, lógicamente, tal responsabilidad a los preceptos constitucionales en los que los regula (...) exactamente como lo hizo para otros poderes del Estado (Corona, Gobierno, Administración y Tribunales) en sus títulos respectivos. En consecuencia, si pudiendo y debiendo haber hablado, calló, es porque tal responsabilidad quiso excluir: 'ubi lex voluit dixit, ubi nolit, taquit' (1999: p. 69).

De forma similar, Aylwin Azócar (1960: p. 19) es partidario de la tesis que sostiene la irresponsabilidad del Estado Legislador, salvo que una ley expresamente acordara lo contrario a favor de los afectados por su entrada en vigencia o aplicación.

Desde otro punto de vista, se presenta el argumento recurrente citado por algún sector de la doctrina en contra de esta figura: la ley al ser una norma de carácter general y abstracta no afecta situaciones jurídicas de personas determinadas, sino que su aplicación beneficia o perjudica a todos por igual. Ello significa que no produciría un daño especial a algunos individuos y, por tanto, el Estado no tendría el deber de indemnizar aquel daño. La especialidad a que se hace alusión, según Vedel (1980: p. 323), se refería a que el perjuicio alegado ha de estar individualizado o ser individualizable, es decir, que no afecte a la totalidad de los individuos destinatarios de la norma, pues sólo en aquel caso se lo entendería como anormal y antijurídico.

Leguina Villa también se opone radicalmente al formulado sistema de imputación, rechazando todos los argumentos propuestos, encontrando que la posibilidad planteada en la Constitución -de expropiar y compensar el interés patrimonial de un particular a favor del bien público-, descarta una responsabilidad por el acto del 
legislador, que de entrada está abordando una compensación en la ley expropiatoria. El tratadista no rechaza cualquier argumento a favor de la teoría de la responsabilidad del Estado Legislador, pero cree que los propuestos, aún son incipientes para que ésta tenga su aplicación (1993: pp. 413 y ss.). Adicionalmente, el tratadista español afirma:

No está en el 9.3, en ese inespecífico principio de responsabilidad de los poderes públicos, en donde alguna vez se ha apoyado esta llamada responsabilidad. Yo creo que no la hay, que lo que se consagra es que los poderes públicos no son irresponsables, pero cada uno de ellos responderá por la modalidad de la responsabilidad y por el tipo, según de qué tipo de poder público se trate y de acuerdo con el resto del articulado que la Constitución diga (1992: p. 128).

Igualmente, García de Enterría ha negado con carácter general la admisibilidad de la responsabilidad del Estado Legislador, aun salvando algunos supuestos, con el ánimo de generalizar la garantía de los ciudadanos en un entorno jurídico-político muy concreto. De este modo, el insigne maestro indica:

Definiendo la Ley el ámbito de lo jurídico positivo, mal puede imputarse a sus efectos un perjuicio antijurídico. Los perjuicios derivados de las leyes son cargas legales y no daños; aunque podría afectar la indemnización a los efectos dañosos de una ley formal cuando se entiende que tal Ley presenta una laguna sobre la materia, y en virtud de la integración de tal laguna con los principios generales del Derecho, pero siempre que esté claro que tal laguna no existe, por ejemplo, porque está implícito el propósito decidido de no indemnizar, y mucho más cuando este propósito está preceptivamente declarado, no existen medios técnicos para forzar a la indemnización (1956: p. 192).

Además, sostiene el destacado tratadista español, que el Tribunal Supremo está reconociendo con una notable liberalidad la posibilidad de obtener indemnizaciones por los perjuicios que para los particulares pueden derivarse de la aplicación de ciertas leyes, tanto del Estado como autonómicas. Expresa que del principio de responsabilidad del Estado -contenido en el artículo 9 de la Constitución española- no es posible extraer una figura de responsabilidad patrimonial del Estado, sino solamente una responsabilidad de naturaleza política, y que los Tribunales contenciosoadministrativos carecen de competencia para proferir sentencias de condena contra el Legislador (2007: pp. 31 y ss.). 
Desde una perspectiva un tanto más práctica, también se ha expresado que reconocer el derecho a la indemnización por actos del legislador podría paralizar la evolución legislativa por la enorme cuantía de las sumas que deberían abonarse. El progreso social -ha dicho- no puede detenerse a causa de los intereses individuales (Núñez, 2011: p. 279), especialmente si se considera que el legislador es uno de los poderes del Estado que no crea directamente recursos, sino sólo los redistribuye.

Por otra parte, y contra estos argumentos y en defensa de la responsabilidad patrimonial del Estado Legislador, Jellinek sostiene que el fundamento actual de la responsabilidad del Estado en sus diversas facetas, no es otro que el Estado de Derecho y sus presupuestos, cuya finalidad última es proteger a los gobernados en sus derechos. Un Estado de Derecho 'irresponsable' significa una contradicción en sus propios términos. Estado de Derecho y responsabilidad serían, entonces, términos correlativos (Núñez Leiva, 2010: pp. 193-194)

Paul Craig, entretanto, estima que el ejercicio del poder de elegir justifica -al menosuna responsabilidad limitada sólo para los casos más graves en la apreciación del poder. De hecho, el ejercicio de ese poder implica una decisión difícil, que es más una opción política. Asimismo, la responsabilidad no puede ser considerada para las decisiones tomadas dentro del poder concedido. En efecto, con intención de proteger y garantizar el ejercicio del Parlamento, se rechaza la hipótesis de responsabilidad patrimonial del Legislador en razón de que el poder legislativo no sea obstaculizado por la perspectiva de las acciones por daños y perjuicios. Sin embargo, todo este planteamiento está equivocado por una sencilla razón: la libertad de actuación que asume el Parlamento no le autoriza emitir comandos normativos flagrantemente ilegales, ilegítimos, que van en contra de todo el sistema de jurídico, y resultan manifiestamente dañosos a los ciudadanos, que no tienen el deber de soportar tales comandos (Da Silva Santos, 2012: pp. 197-198). 
A su vez, Caldera Delgado (1982: p. 51), Celdrán Ruano (1996: pp. 11 y ss.) y Zúñiga Urbina (2005: p. 16) comparten la idea de que basta un perjuicio que constituya un atropello a un derecho fundamental para que dicha ley sea -además de inconstitucional-, la causa de una indemnización reparatoria.

En el mismo sentido, Xiol Ríos sostiene cómo -inicialmente-, el reconocimiento de una responsabilidad por daños, imputable al Legislador, resulta un fenómeno no muy comprensible, en razón de la formación histórica de la significación de las leyes 424 . Sin embargo, el principio de responsabilidad patrimonial del Estado por actos legislativos se conecta con el principio de subordinación de la ley a la Constitución (2007: pp. 1034-1035). Así pues, el tratadista español advierte:

El principio de responsabilidad patrimonial del Estado legislador sólo es posible cuando el concepto de ley evoluciona desde el punto de vista de su inserción en el ordenamiento, y desde el punto de vista de su contenido. Desde el primero de los citados puntos de vista, la ley deja de ser el producto de un poder soberano, pues aparece subordinado a una norma más fuerte, que es la Constitución, e incardinada en ordenamientos supranacionales que, limitando la soberanía del Estado, pueden imponer limitaciones a todos los poderes internos, entre ellos el legislativo. Desde el segundo año de los citados puntos de vista, la ley -como consecuencia de las nuevas situaciones a las que en virtud del dinamismo social debe atender-, pierde en ocasiones su carácter general. Junto a las leyes de presupuestos y de acompañamiento presupuestario, que incorporan con diversos efectos legitimadores las medidas de política económica, la ley se convierte a veces en un acto equivalente a los actos emanados del Poder ejecutivo, en la medida en que refleja las previsiones propias de un instrumento de planificación (leyes marco, leyes de planeamiento) o apto para dar efectividad a medidas concretas de transformación de la realidad (leyes medida / 2007: p. 1035).

Pues bien -bajo el punto de vista de la jurisprudencia- será desde el 14 de enero de 1938 que el Consejo de Estado francés abrirá la puerta para el reconocimiento expreso del derecho a la indemnización por parte del Estado Legislador, mediante la sentencia proferida dentro del caso "Societé Anonyme des produits laiters La Fleurette" ('sociedad fabricante de cremas y otros productos derivados de la leche', forzada a cerrar como consecuencia de una ley que prohíbe su fabricación para protección de la industria lechera francesa). En esta decisión, el Consejo de Estado, ante el silencio de la ley sobre medidas resarcibles, admite la procedencia de la indemnización fundándose, además de la existencia de un sacrificio especial y en la transgresión del principio de la 
igualdad ante las cargas públicas, en la presunción de una voluntad indemnizadora del legislador, que silencia pero no excluye la indemnización (Celdrán Ruano, 1996: p. 27).

El sistema de responsabilidad expuesto en este fallo del Consejo de Estado francés, se fundamentó en un principio de armonía y equilibrio de extrema fragilidad. El compromiso entre el respeto a la voluntad del legislador y el principio de igualdad ante las cargas públicas tendía a romperse por el término más débil: el respeto a la voluntad del legislador, de cuyo carácter ficticio la jurisprudencia del Alto Tribunal fue tomando conciencia a lo largo de las decisiones que ha debido tomar, para que, finalmente, sobreviniera la ruptura definitiva del sistema con la dictación del "Arrêt Bovero" en 1963, providencia basada ahora directamente en la vulneración del principio de igualdad ante las cargas públicas y, sobre todo, en la formulación general de la teoría de la responsabilidad del Estado Legislador, deducible -no como antes-, de la interpretación de la ley causante del daño, sino de la ausencia de exclusión expresa en la propia ley del derecho a indemnización (Celdrán Ruano, 1996: p. 28).

Adicionalmente, agrega Celdrán Ruano:

Con este límite (exclusión expresa), y otra serie de condiciones exigidas por la jurisprudencia del Consejo de Estado ante el silencio de una ley sobre indemnización (que el perjuicio sea especial y de una gravedad suficiente; que la naturaleza de las actividades que afectan la ley no sean de carácter regresivo ni fraudulento, o que la ley no actúe 'en interés general preeminente'), se ha desarrollado en el sistema francés este peculiar régimen de garantías del ciudadano frente al legislador, si bien que restrictivamente, como se muestra el hecho de que, desde 1938 ('la Fleurette') a 1963 (Bovero), sólo se ha reconocido derecho a indemnización en dos casos: 'Arrêts caucheteux et desmont' (1944) y 'Lacombe' (1961) (1996: pp. 28-29).

Así las cosas, Zúñiga Urbina (2005: pp. 129-130) ha sintetizado las reglas que se han decantado y consolidado desde el "Arrêt La Fleurette" acerca de la responsabilidad del Estado Legislador, a saber:

- La fuente de responsabilidad son las leyes formales y no los reglamentos o actos de ejecución de una ley. 
- Cuando la ley guarde silencio acerca del régimen reparatorio, la responsabilidad del Estado Legislador está ligada a la intervención limitativa o ablatoria de derechos.

- El juez deduce -a partir de la interpretación de la ley-, un consentimiento a la indemnización. La reparación puede estar contenida en la ley, o bien omitida por el legislador y, en este último evento, el juez puede desprender la anuencia a la indemnización.

- La responsabilidad del Estado Legislador se fundamenta en el principio de igualdad ante las cargas públicas: la ley impone, a un pequeño número de particulares identificables a pesar de la generalidad de los términos empleados-, un perjuicio especial.

- El interés general en nombre del cual el sacrificio es impuesto, no debe ser confundido con el interés de una categoría social o económica.

- La actividad sacrificada, que da origen al daño indemnizable, no debe ser ilícita, ni inmoral, ni peligrosa para la colectividad.

- El daño indemnizable y la gravedad sobrepasa los normales sacrificios impuestos por la legislación.

La denominada responsabilidad del Estado Legislador "comprende todos aquellos supuestos cuyo común denominador se encuentra en los daños económicamente evaluables que resultan de la actividad legislativa y que acarrean la obligación de resarcimiento" (Ruiz López, 2013: p. 3). Sin embargo, este concepto implica no pocas dificultades que entraña este tema. De una parte, no son ni mucho menos inequívocos los perjuicios que pueden derivarse del contenido de las disposiciones contenidas en las leyes; de otra parte, tampoco resulta pacífica la cuestión de la exigibilidad de la indemnización. Es más, la exagerada liberalidad con la que se ha admitido la responsabilidad del legislador en la práctica de los Tribunales contencioso- 
administrativos, no siempre ha ido acompañada de la necesaria reflexión, sino que, al contrario, la jurisprudencia ha dado muestras de sus muchas dudas y contradicciones a lo largo del tiempo, sosteniendo una cosa y la contraria sin una aparente justificación (Garrido Falla, 1993: pp. 125 y ss.).

Así, el tratadista Serra Rojas (1973: pp. 835-836) ha señalado que la responsabilidad del Estado Legislador se establece cuando el Poder Legislativo expide leyes inconstitucionales y son declaradas como tales por el juez o tribunal competente, o leyes por fuera de la competencia del funcionario, o leyes que causen perjuicios indebidos a los particulares, pero que dicha Ley reconoce expresamente la obligación de indemnizar los posibles perjuicios que de su aplicación se causen; o leyes que causen perjuicios indebidos a los particulares, pero que dicha Ley silenció en cuanto a una indemnización por los daños irrogados, dejando a los jueces en libertad de decidir sobre el particular. En estos casos, el particular tiene derecho a una indemnización por los daños y perjuicios que le cause la Ley.

De esta manera, como hipótesis de daños irrogados por el Estado Legislador a los particulares, pueden señalarse, entre otras, las siguientes: a) una ley de nacionalización de determinadas actividades o empresas privadas; b) una ley que establezca un monopolio con privación de una actividad privada lícita; c) una ley que califica como bienes de dominio público los que antes eran de dominio privado; d) una ley que adelante o retarde la edad de jubilación, en cuyo caso habrá que entrar a determinar si los trabajadores en la relación laboral gozan de expectativas o de derechos subjetivos, debido a que se modifican sobrevenidamente las condiciones originales de ingreso al trabajo; en el primer caso no podrán gozar íntegramente de la jubilación y, en el segundo, deberán trabajar más tiempo del que inicialmente se laboró.

No obstante, es pertinente advertir que si la Ley afecta a la totalidad de la población o a una categoría entera y completa de personas presentando idéntica situación profesional, industrial, comercial y espacial, no hay daño especial (Da Silva Santos, 2012: p. 203). 
Pues bien, es importante recalcar cómo el aparato jurisdiccional del Estado tiene la potestad de interpretación frente al texto legal, para establecer si existe o no responsabilidad del Estado Legislador.

Adicionalmente, se ha señalado que para la procedencia de la responsabilidad patrimonial del Estado Legislador, se requiere de los supuestos (Núñez Leiva, J.I., (2011: pp. 219-222):

1. La existencia de una norma legal que en su aplicación cause daños a particulares.

2. Que aquellos daños se irroguen sobre derechos fundamentales

3. Que aquel daño sea antijurídico, esto es, que su ocurrencia no se encuentre autorizada por el ordenamiento jurídico y, por tanto, la persona no esté obligada a soportarla.

En este sentido, Xiol Ríos ha señalado:

El principio de responsabilidad patrimonial del Estado legislador sólo es posible cuando el concepto de ley evoluciona desde el punto de vista de su inserción en el ordenamiento y desde el punto de vista de su contenido. Desde el primero de los citados puntos de vista, la ley deja de ser el producto de un poder soberano, pues aparece subordinado a una norma más fuerte, que es la Constitución, e incardinada en ordenamientos supranacionales que, limitando la soberanía del Estado, pueden imponer limitaciones a todos los poderes internos, entre ellos el legislativo. Desde el segundo de los citados puntos de vista, la ley, como consecuencia de las nuevas situaciones a las que en virtud del dinamismo social debe atender, pierde en ocasiones su carácter general. Junto a las leyes de presupuestos y de acompañamiento presupuestario, que incorporan con diversos efectos legitimadores las medidas de política económica, la ley se convierte a veces en un acto equivalente a los actos emanados del Poder ejecutivo, en la medida en que refleja las previsiones propias de un instrumento de planificación (leyes marco, leyes de planeamiento) o apto para dar efectividad a medidas concretas de transformación de la realidad (leyes medida) (2007: pp. 1034-1035).

En este orden de ideas, se trata de un tema destacado para la teoría constitucional, entre otras razones porque involucra la concreción y aplicación de los principios integrantes del Estado Constitucional de Derecho, se funda en la teoría de los derechos humanos, abre una nueva perspectiva en la relación de pesos y contrapesos en un Estado con separación de funciones, concentra la concepción servicial del Estado y 
crea un nuevo punto de relación entre co-legisladores y juzgadores, aumentando la red de garantías a los derechos fundamentales, redefiniendo las competencias de los órganos del Estado e impactando, además, en el sistema de fuentes del derecho, pues proporciona nuevos efectos a diferentes normas fundamentales (Núñez Leiva, 2008: p. 131-132).

Además, porque el amparo de los derechos fundamentales impone a todas las potestades públicas -incluso el Legislador-, la obligación de indemnizar todas las lesiones que estos poderes causen a los derechos considerados fundamentales, inclusive aquellas que produzcan las leyes. De tal modo que el Legislador debe ajustarse en sus prescripciones a los mandatos constitucionales, debido a que el poder legislativo no es soberano ni omnipotente y, por lo tanto, los ciudadanos deben estar protegidos de la arbitrariedad del poder público (Da Silva Santos, 2012: pp. 192-194).

Ciertamente, el derecho a la reparación de los daños constituye una garantía de limitación del poder, y postula un comportamiento general de respeto por parte de los diferentes Poderes Públicos, es decir, cubre todas y cada una de las funciones del Estado. Precisamente, el derecho de indemnización, resultado del reconocimiento de la responsabilidad del Estado Legislador, presenta su contenido esencialmente determinado a nivel constitucional, no dependiendo de ley ordinaria para tornarse líquido y cierto, y tampoco constituye una norma programática. En esa medida, es directamente aplicable, pudiendo ser invocado por el lesionado (Da Silva Santos, 2012: p. 200).

Ahora bien, para sustentar el reconocimiento de la responsabilidad del Estado Legislador, se han planteado diversas teorías, entre las que podemos destacar la del perjuicio especial y la del enriquecimiento sin causa.

\subsubsection{El perjuicio especial}

Esta teoría originada en la doctrina alemana, tiene como fundamento que la actividad estatal no puede producirse sin que los particulares sufran algunos perjuicios. Cuando 
esos perjuicios afectan a un individuo de manera desproporcionada y desigual, entra en juego el concepto de equidad, y si el perjuicio se traduce en un daño material habrá lo que se denomina 'sacrificio especial', el cual debe ser indemnizado.

El destacado jurista Otto Mayer (1954, T. IV: pp. 216-218) sostiene que cuando se hace referencia de 'sacrificio especial' es porque hay un daño material causado por una Ley a los intereses particulares. El sacrificio especial en su concepto da origen a la obligación de indemnización que incumbe al Estado.

\subsubsection{El enriquecimiento sin causa}

Se puede presentar el caso en que una Ley en sí misma no sea fuente de la indemnización, porque ella no genera daño; sin embargo, dicha Ley implica un enriquecimiento de la Administración, del cual emana una responsabilidad estatal.

Sobre el particular, el tratadista francés Hauriou (Serra Rojas, 1973: p. 837) señala como requisitos para que se configure el enriquecimiento sin causa, los siguientes:

- Que el daño irrogado al particular debe ser directamente producido por la Ley que genere el enriquecimiento del patrimonio del Estado.

- El enriquecimiento debe ser sin justa causa, es decir, producido por el ejercicio de un derecho de la Administración que es excepcional al derecho común.

Otto Mayer (1954, T. IV: pp. 216-218) advierte que en materia de enriquecimiento sin causa no pueden invocarse como base jurídica principios del Derecho Civil -referentes a la restitución de lo debido-, pues aun cuando en los hechos que dan lugar a la indemnización puede haber algo que se parezca a un enriquecimiento del Estado a costa del administrado, esto no es esencial y la indemnización corresponderá aunque el Estado no haya obtenido ninguna ventaja positiva. 
Meyer no niega que pueda haber una gran similitud entre la institución del Derecho Civil que es el enriquecimiento sin causa y la indemnización. Tiene un punto en común, del cual emanan ambas, y es la idea de equidad o la 'naturalis aequitas'.

La diferencia entre la noción de enriquecimiento sin causa del derecho privado y el concepto de indemnización en el derecho público radica en que en el Derecho Civil mientras que por un mismo hecho un individuo gana, otro pierde algo; en cambio, en el Derecho Público -en la relación Estado-particular-, no se trata de evaluar las pérdidas y ganancias recíprocas sino del efecto que surte la actividad del Estado sobre los individuos.

\subsection{REFLEXIÓN}

El legislador posee libertad de configuración y de regular o desarrollar todas aquellas materias necesarias para la existencia de la organización política.

La responsabilidad del Estado por la actividad legislativa del Congreso de la República, es relativamente reciente, y no ha sido un asunto pacífico, puesto que en principio se afirmaba que la ley era un acto soberano que beneficiaba a todos los coasociados; por lo tanto, los daños que se causaban con la actividad legislativa, no daban derecho a indemnización de clase alguna porque no se puede limitar la facultad del pueblo soberano a autorregularse, y sólo el mismo legislador podía establecer si había lugar a una compensación cuando -con ocasión de una de sus leyes- se causara un daño a un administrado, posición que se veía reforzada por la ausencia de control de la constitucionalidad de las leyes.

Sin embargo, desde la mitad del siglo XX, la paulatina generalización del control de constitucionalidad de las leyes en la mayoría de ordenamientos jurídicos, ha conducido a la jurisprudencia y a la doctrina a considerar que el principio de soberanía y de libertad configurativa del legislador pueden estar en algunas ocasiones en colisión con el de la supremacía del derecho, característico del constitucionalismo y del estado de 
derecho,abriéndose de este modo la puerta para el reconocimiento expreso del derecho a la indemnización por parte del Estado Legislador.

La denominada responsabilidad del Estado Legislador cobija todos aquellos supuestos cuyo común denominador se encuentra en los daños económicamente evaluables, que devienen de la actividad legislativa, y conducen a su vez a la obligación de reparación. 


\section{ASPECTOS PUNTUALES DE LA RESPONSABILIDAD DEL ESTADO LEGISLADOR FRENTE AL DERECHO COMPARADO}

La posibilidad de hacer responsable al Estado de los daños que ocasione el ejercicio de la actividad legislativa, si bien en un principio resultó de manera generalizada en el Derecho Comparado como impensable, no obstante, el debilitamiento de conceptos como la ley, la soberanía y la voluntad popular hicieron prosperar la discusión en dicho contexto en torno a esta clase de responsabilidad.

De este modo, el planteamiento de la teoría de la responsabilidad del Estado Legislador es relativamente reciente en el Derecho Comparado, puesto que su formulación en algunos ordenamientos jurídicos data de más o menos un siglo, y aún no ha logrado una aceptación generalizada, como consecuencia elemental de alterar los más profundos reductos de la libre decisión política y de la soberanía (Santamaría Pastor, 1972: p. 62).

Así las cosas, entonces en el Derecho Comparado es menester indicar que países como Francia y España presentan un admirable desarrollo tanto doctrinal y jurisprudencial en lo pertinente a la responsabilidad del Estado Legislador. Entretanto, en países como Italia, Alemania y Estados Unidos aún es tímido el desarrollo doctrinal y jurisprudencial, y éstos poseen regulaciones sumamente restrictivas y conservadoras sobre el particular.

\subsection{FRANCIA}

En el sistema contencioso-administrativo francés del siglo XIX, el dogma de la irresponsabilidad del Estado Legislador triunfa plenamente. Así, por ejemplo, el 11 de enero de 1838, por primera vez, se estudió a fondo por parte del Consejo de Estado la responsabilidad del Estado Legislador, aunque el tema ya había sido tratado a nivel 
doctrinario. Ciertamente, en dicho año el 'Conseil d'Etat' sostuvo en el fallo 'Duchatelet' una posición de irresponsabilidad total y absoluta del Estado Legislador (Amalfi Álvarez \& Cala Moncaleano, 1984: pp. 114-115). El señor Duchatelet era fabricante de tabaco facticio, estilo que no es natural y se realiza por arte; sin embargo, una ley del 12 de enero de 1835, cuyo espíritu era únicamente garantizar mejor el monopolio fiscal de los tabacos y que no alegó contra los fabricantes el carácter nocivo para la salud pública del tabaco facticio, y tampoco contempló indemnización alguna para aquellos fabricantes que resultaren lesionados por dicha prohibición (Gamba Ladino, 2005: pp. 267-268).

A decir verdad, el Consejo de Estado no se atribuyó el poder -en el silencio de la Ley-, de fijar esa indemnización. Para tal efecto consideró que el Estado no podía ser responsable de las consecuencias de una ley que en razón de un interés general prohibiera el ejercicio de una industria, a menos que las disposiciones especiales contenidas en la misma se pronunciaran específicamente sobre el punto (Amalfi Álvarez \& Cala Moncaleano, 1984: pp. 114-115).

En esa oportunidad, el 'Conseil d'Etat' no se abrogó más competencia de la que tenía para decretar la indemnización; simplemente consideró que el Estado no podía ser responsable de las consecuencias de una ley cuyo fundamento era nada menos que el interés general. La posición jurisprudencial descrita se enmarcó en un período de tiempo en el cual la responsabilidad estatal en general era reconocida de manera precaria, y fundamentada en la generalidad de las leyes y en la soberanía, puesto que como señalaba Laferriere lo propio de ésta es "imponerse a todos sin que se pueda reclamar de ella ninguna compensación. Las jurisdicciones no pueden asignarla en su lugar" (Torregoza Sánchez, 2007: pp. 14-15).

No obstante, muy a pesar de los sólidos argumentos que sustentaban la irresponsabilidad, es en Francia donde maduran las primeras teorías sobre la responsabilización del Estado en los daños ocasionados por el ejercicio de la actividad legislativa (Pia Larné, 2008: pp. 210-211), en buena medida gracias a la influencia de 
Dugiut y su escuela, que efectuaron fuertes críticas a la tesis de la irresponsabilidad del Estado como consecuencia de la soberanía, críticas que permitieron un viraje en la orientación de la doctrina y la jurisprudencia sobre el particular (Retis, 2005: p. 67).

De este modo, la jurisprudencia del 'Conseil d'Etat' comenzó a ser flexible, y reconoció por primera vez el derecho a recibir una indemnización a los 'co-contratantes' del Estado, que con ocasión de nuevas disposiciones legales se vieran inmersos en nuevas e imprevistas prestaciones. Así, en providencias de 1906, 1929 y 1939 el Consejo de Estado francés reconoció el derecho a la indemnización a dos sociedades mineras concesionarias del Estado, por los perjuicios causados como resultado de los poderes otorgados por la ley de 27 de junio de 1880 a los prefectos, para prohibir los trabajos subterráneos en las inmediaciones de las líneas del tren (Amalfi Álvarez \& Cala Moncaleano, 1984: pp. 114-115).

Sin embargo, con excepción de los anteriores casos, el órgano central de la justicia contencioso-administrativa francesa, continuó rechazando las demandas que pretendieran una indemnización por el perjuicio causado por una ley; empero, el fundamento de tales providencias ya no se circunscribía a motivos tan generales y absolutos como los del fallo 'Duchatelet'y aquellos que le prosiguieron.

Así, por ejemplo, la sociedad 'Premier y Henry' -fabricante de ajenjo- solicitó la indemnización de perjuicios irrogados por la expedición de una ley de 1915, que prohibió la fabricación de ajenjo; el Consejo de Estado francés rechazó la demanda tomando como fundamento la finalidad misma de la ley: impedir la fabricación de productos peligrosos para la salud (Dromi, 1979: p. 203). En igual sentido, los señores 'Fleury y Hauguel' demandaron una indemnización al Estado por el perjuicio que habían sufrido como consecuencia del establecimiento de un monopolio provisorio de alcohol; el 'Conseil d'Etat', nuevamente, considerando que ningún texto legislativo había previsto el otorgamiento de una indemnización para los industriales cuyos intereses podían ser afectados por el régimen instituido en vista de la defensa nacional, rechazó la demanda (Caldera Delgado, 1982: pp. 103-104). 
Pero, en 1938 la posición jurisprudencial adoptada por el Consejo de Estado de Francia desde el destacado fallo "Duchatelet" de 1838, fue superada con el famoso fallo " $\mathrm{La}$ Fleurette", que fue la primera providencia -en dicho país- que condenó al Estado a indemnizar por daños causados por una Ley. La 'Societé des produits 'La Fleurette' era una sociedad que fabricaba una crema sana e higiénica llamada 'Grandine', cuya composición era un setenta por ciento $(70 \%)$ de leche y un treinta por ciento $(30 \%)$ de otras sustancias. El 29 de junio de 1934 se expidió una ley con el único propósito de fomentar los productos lecheros, prohibiendo su fabricación y comercialización de este modo, de otros productos inofensivos pero no elaborados con leche cien por ciento o con poco ingrediente lácteo, lo cual afectó casi exclusivamente a la sociedad " $L a$ Fleurette" (Caldera Delgado, 1982: pp. 103-106). El Consejo de Estado analizó si realmente la intención del legislador fue la que sufrió esta sociedad, llegando a la conclusión negativa. El tribunal también analizó si la actividad económica ejecutada por la sociedad demandante era lesiva para el interés general, llegando a la misma conclusión; por lo tanto, procedía la indemnización deprecada (Gamba Ladino, 2005: p. 268).

De hecho, los principios dominantes que de allí resultan en materia de responsabilidad son: no hay indemnización si el legislador la ha rechazado; la actividad que resulta suprimida debe ser lícita; el perjuicio, por su especialidad y gravedad, debe sobrepasar el normal de las cargas que impone la ley; ésta ha debido dictarse no en interés general sino de un grupo (García de Enterría, 2007: p. 17; Vidal Perdomo, 2004: p. 405; Zúñiga Urbina, 2005: pp. 37-38.).

Igualmente, en el fallo "Caucheteux et Desmont" de 21 de enero de 1944 se accedió a las pretensiones invocadas por la sociedad demandante con ocasión de los perjuicios irrogados por la ley del 9 de julio de 1934, la cual buscaba favorecer la producción de cereales, disminuyendo el porcentaje de otros productos diferentes a la cebada, como la glucosa, que se utilizaba para la fabricación de la cerveza. En dicha oportunidad, al comprobarse que la glucosa no era sustancia tóxica, el Estado debió responder e 
indemnizar a la sociedad afectada por la expedición de la mencionada ley (Sayagués Lasso. 1963, T. I: p. 614).

Asimismo, en el fallo Bovero de 23 de enero de 1963, que inició por un problema de ejecución de una sentencia en la que se había logrado el desahucio de un arrendatario, antes de ejecutarse la sentencia, se profirió el 3 de enero de 1959 una ordenanza con fuerza de ley que prohibió la expulsión de los militares en servicio y alojados en Argelia, así como sus familias. En primer lugar, el arrendador acudió a la Administración y al no tener éxito para la expulsión de los arrendatarios, presentó demanda ante el 'Conseil d'Etat', deprecando el daño ocasionado por la ordenanza con fuerza de ley; en esta oportunidad el Alto Tribunal francés señaló:

(...) No obstante, al enervar la ejecución de una decisión judicial definitiva, la aplicación de la antedicha ordenanza de 3 de enero de 1959 causa a aquéllos en cuyo favor se había dictado la decisión judicial inejecutada en perjuicio grave cuya duración lo hace particularmente gravoso; que tal perjuicio no se ha producido ni a todos los propietarios de viviendas ocupadas por terceros ni a una categoría de ellos, sino sólo a aquellos cuyas viviendas se hallan ocupadas por un militar en servicio en África del Norte en el momento en que debía haberse producido la ejecución de una orden de desahucio dictada en su favor 0 por las personas cuyo padre, que convivía anteriormente con ellas, sirviese en dicho momento como militar en África del Norte; que tal perjuicio constituye, para aquellos que lo experimentan, una carga especial con relación al conjunto de cargas normales que incumben al conjunto de propietarios de viviendas ocupadas por terceros; y que, por su gravedad y especialidad, tal perjuicio presenta un carácter excepcional suficiente para determinar, en el silencio de los preceptos legales, la 'responsabilité sans faute' del Estado (Santamaría Pastor, 1972: pp. 92-93; Soriano García, 1981: p. 583).

Con este fallo sobre locales arrendados a militares de la guerra de Argelia, el Consejo de Estado determinó que la omisión legislativa dejó de ser un obstáculo, y la no inclusión de indemnización por el legislador debía interpretarse favorablemente al demandante, pero como se puede deducir no deja de ser una posible declaratoria de responsabilidad sobre un daño causado a un grupo específico de personas. En Este fallo se aceptó la posibilidad de conceder la compensación económica como consecuencia de la actividad del legislador, pese a que expresamente la indemnización no fue consagrada por el mismo (Garrido Mayol, 2004: p. 135; Ruíz Orejuela, 2011: p. 106). Además, a diferencia del fallo "La Flaurette" -que imponía al demandante probar la voluntad del legislador pese a la omisión de la ley-, se trataba de otorgar la 
indemnización, mientras en el fallo Bovero se desplazaba la carga de la prueba a favor del perjudicado (Ruíz Orejuela, 2011: p. 110; Santamaría Pastor, 1972: pp. 93-94).

De este modo se infiere que la jurisprudencia francesa dio un importante viraje con los fallos de la "Societé La Flaurette" del año 1938, "Cacheteux et Desmont" de 1944 y "Bovero" de 1963, que admitieron el principio de la responsabilidad del Estado por actos del Legislador, en virtud de la igualdad de los particulares ante las cargas públicas (Retis Amaya, 2005: p. 69).

Ahora bien, las reglas impuestas por el "Arret 'La Fleurette'", se han extendido a daños originados en tratados internacionales incorporados al derecho interno, según lo confirman "Arret 'C. Générale D'Energie Radioelectrique' " (1966) y "Burgat" de 1976 (Retis Amaya, 2005: p. 70).

Sin embargo, posterior a estos pronunciamientos en Francia se reconoció la responsabilidad del Estado Legislador en fallos excepcionales, en los que era evidente la injusticia (Galán Vioque, 2001: p. 315; García de Enterría, 2007: p. 17; Sayagues Lasso, 1963, T. I: p. 614). En efecto, en los más de tres cuartos de siglo transcurridos hoy, ha habido una reducidísima serie de repeticiones de la doctrina "La Fleurette", que no pasan de cinco, a saber: Los fallos "Caucheteux" de 1944, "Lacombe" de 1961 "Bovero" de 1963, "C.P.P.R.I." de 1981 y "S.C.I. La Cardinale" de $1991 .^{5}$

Ciertamente, la propia y excepcionalísima jurisprudencia francesa ha excluido de forma expresa que la doctrina de la responsabilidad pueda aplicarse a cualquier Ley que se haya dictado en atención de un interés general y preeminente, o en atención a un interés económico y social de orden general, o cuando la propia Ley ha previsto un

\footnotetext{
${ }^{5}$ Es más, en Francia, de manera reciente, un importante sector de la doctrina encabezado por el insigne tratadista Jean Rivero, sigue justificando el principio de irresponsabilidad del Estado Legislador, al considerar que "es jurídica y prácticamente imposible declarar una falta en la actividad legislativa, soberana por definición; el juez no podría, de otra parte, hacer derivar de una Ley una responsabilidad sin falta, sin añadir algo a la voluntad del legislador, es decir, sin sustituirle. El Consejo de Estado, en ciertas hipótesis excepcionales, sin embargo aceptadas, no solamente se ha reconocido competente, sino que además ha admitido además una responsabilidad por hecho (derivado) de la Ley” (Celdrán Ruano, 1996: p. 29).
} 
sistema de compensación de las consecuencias eventualmente dañosas. Nada, pues, que pueda pretender explicarse por virtud del principio superestructural que había formulado Duguit a principios del siglo XX, de que la institución debería ponerse en juego para restaurar la igualdad ante las cargas públicas cuando la Ley infringía ese principio o causaba un 'sacrificio especial' (García de Enterría, 2007: p. 18).

También es importante señalar que en la fecha de aparición tanto del fallo " $\mathrm{La}$ Fleurette" como del fallo "Caucheteux et Desmont", no existía en Francia jurisdicción constitucional sobre las leyes, la cual fue instituida por la Constitución gaullista de la V República (1958), con algunas limitaciones. En la actualidad, cuando se ejercita por el 'Conseil Constitutionnel' el control preventivo de la constitucionalidad de una Ley, es éste quien controla si la Ley tiene efectos limitadores o delimitadores de los derechos 0 , por el contrario, tiene un efectivo contenido expropiatorio, que sólo si va acompañado de la correspondiente indemnización excluye la declaración de inconstitucionalidad (García de Enterría, 2007: p. 18).

De manera que, aunque la vigente Constitución francesa admite por vez primera en la historia constitucional de dicho país ese control superior, limita estrictamente la posibilidad de su planteamiento, que se circunscribe al momento único tras la aprobación de la Ley y antes de su publicación, plazo fugacísimo y perentorio, y que además reduce la legitimación para interponer el recurso de inconstitucionalidad -ante el 'Conseil Constitutionnel'- al Presidente de la República, al Primer Ministro, al Presidente de la Asamblea y a sesenta diputados o senadores, sin que admita en modo alguno la técnica de planteamiento de la cuestión por el juez ordinario o contenciosoadministrativo en el momento de la aplicación de la ley cuestionada, mediante lo que se ha denominado en el marco jurídico colombiano como 'excepción de inconstitucionalidad'.

Con todo, y aunque se fundamente en excepciones, los jueces han conseguido en Francia -cuya Constitución sólo determina un control previo de constitucionalidad de las leyes por el Consejo Constitucional-evitar la vulneración del principio 
constitucional de igualdad, interpretando en estos casos la voluntad del legislador (Celdrán Ruano, 1996: p. 29)

En este orden de ideas, la doctrina francesa actual interpreta y, correlativamente, limita la explicación de la jurisprudencia "La Fleurette" como un simple caso de interpretación de la voluntad del legislador, de manera que sólo será posible declarar la responsabilidad patrimonial de este último si se puede interpretar como implícita la voluntad indemnizatoria (García de Enterría, 2007: p. 19).

\subsection{ALEMANIA}

A resultados similares a los descritos en Francia -aunque con planteamientos teóricos distintos-, se ha llegado en Alemania, en cuyo ordenamiento jurídico, también doctrina y jurisprudencia se han esforzado en poner fin a las inmisiones legislativas en la esfera patrimonial (Celdrán Ruano, 1996: p. 29); y ello, utilizando no sólo los diversos títulos indemnizatorios recogidos en la Ley Fundamental-Constitución de la República Federal de Alemania ('Grundgesetz für die Bundesrepublik Deutschland') de 1949, sino también, y sobre todo, a partir de la admisión del ilícito legislativo, con la creación de un órgano de control de constitucionalidad de las leyes.

De este modo, se obtiene que para 1831 el sistema de protección patrimonial alemán era avanzado para la época: tanto el sacrificio de derechos e intereses como las limitaciones de la propiedad obligaban al Estado a indemnizar. Después de 1831, con la llamada "Allerhöchstte Kabinettsordre" -A.K.O. prusiana de 4 de diciembre de dicho año-, se distinguió entre los actos de administración y los actos de legislación: en este segundo supuesto la obligación de resarcimiento con cargo al patrimonio estatal había de ser consagrada expresamente por la ley (Forsthoff, 1958: pp. 428-436; Nieto, 1962: pp. 70-75) 
Más adelante, la Constitución de la República de Weimar ('Weimarer Republik', de 1919), no admitió más que la figura de la expropiación legislativa ('durch Gesetz') como primer título jurídico indemnizatorio para imponer disciplina a la actividad legislativa. La legitimación constitucional de esta figura hay que conectarla con el proceso expansivo del instituto expropiatorio ante las pretensiones socializantes del texto constitucional de Weimar, en el que el ámbito de las relaciones Ley-propiedad, al regular el instituto expropiatorio en el artículo 153, admitía claramente cualquier posibilidad de intervención de aquélla sobre ésta ("La propiedad está garantizada por la Constitución, su contenido y límites se ajustarán a las Leyes"), aunque remitiendo después a la Administración para que, mediante habilitación legal, llevara a cabo la operación expropiatoria a cambio de una adecuada indemnización, salvo que una ley del Reich determinara cosa distinta (Celdrán Ruano, 1996: pp. 29-30).

Sobre el particular, la reacción de la doctrina y jurisprudencia ante estas limitaciones constitucionales no se hizo esperar: resistencia a aplicar las exclusiones legales a la indemnización, y admisión -junto a la forma tradicional de expropiación realizada por la Administración mediante acto interpuesto— de la expropiación legislativa: "allí donde la expropiación se efectúa por una Ley del Reich - diría el 'Reichsgericht' en una conocida sentencia- el fundamento legal está contenido en la Ley misma" (Santamaría Pastos, 1972: p. 104). El argumento utilizado por el Alto tribunal fue el siguiente: si la Constitución no consagra una reserva expresa de competencia a favor del Ejecutivo para expropiar -y la Ley puede habilitarle para ello-, también puede expropiar la propia Ley. La consecuencia es clara: extendiendo el instituto expropiatorio a los actos del legislativo, la indemnización, presupuesto inexcusable del mismo, estaba asegurada.

Así las cosas, la experiencia alemana alcanzada con la Constitución de la República de Weimar ('Weimarer Republik' de 1919), permitió poner en evidencia, antes que cualquier otro ordenamiento jurídico, lo inadecuado del dogma de la soberanía y supremacía de la ley respecto a la cambiada realidad social y política; y es precisamente el Tribunal Supremo alemán el que instituye el primer control de hecho 
sobre leyes 'arbitrarias', es decir, que violan la propiedad y el principio de igualdad contemplados en la Constitución (Pia Larné, 2008: pp. 210-211).

Por lo demás, fue precisamente a través de la jurisprudencia que se desarrolló sobre el artículo 153 de la Constitución de Weimar (cuyo fin es la tutela de la propiedad y de la expropiación), que en el ámbito del sistema del resarcimiento del daño por lesión de los derechos en cuestión, se dio por primera vez la extensión del concepto clásico de expropiación por las operaciones "previstas por la ley" a todas las "situaciones jurídicas patrimoniales" y a los "límites a la propiedad" (Reichsgericht-RG, sent. del 18 de noviembre de 1921, del 22 de febrero de 1924, del 13 de diciembre de 1924 y del 11 de marzo de 1927). Acto seguido, la responsabilidad fue reconocida incluso en el caso de operaciones antijurídicas (Reichsgericht-RG, sent. del 11 de abril de 1933).

Con posterioridad a la Segunda Guerra Mundial, la Ley Fundamental para la República Federal de Alemania ('Grundgesetz für die Bundesrepublik Deutschland', promulgada el 23 de mayo de 1949), al igual que su antecesora la Constitución de la República de Weimar, consagró la responsabilidad estatal, desarrollada en torno al elemento culpa (Retis Amaya, 2005: p. 73) , componente que desaparece el primero de enero de 1982 con la entrada en vigor de la Ley de Responsabilidad Patrimonial del Estado de 26 de junio de 1981, como resultado de la consagración de la responsabilidad objetiva (Embid Irujo, 1982: pp. 353-381; Sainz Moreno, 1982: pp. 381-393).

La Ley de Responsabilidad Patrimonial del Estado dispuso en su artículo 5을 inciso $2^{\circ}$ que: "Si consiste la infracción del deber en un comportamiento antijurídico del legislador, tendrá lugar la responsabilidad sólo cuando y en la manera en que la ley lo determine. La responsabilidad por infracciones del deber del poder ejecutivo o judicial, que se basen exclusivamente en el comportamiento del legislador, no queda afectada".

De este modo, el primer supuesto se configuraba cuando irrumpía una expropiación sin justa causa. Por consiguiente, una ley materialmente expropiatoria, debía consagrar la justa indemnización "Junktim-Klausel", so pena de que el Tribunal Constitucional la 
declarara inconstitucional ${ }^{6}$, y a partir de dicho pronunciamiento pudiera predicarse jurídicamente el deber de otorgar la indemnización. Al respecto, el Tribunal Constitucional de la República Federal alemana ('BverfG') con base en el artículo 14 de la 'Grundgesetz' que consagra el derecho a la propiedad, ha señalado de manera enfática que las leyes materialmente expropiatorias que no consagren los criterios suficientes y el procedimiento para la justa indemnización, son inconstitucionales.

A su turno, el segundo supuesto se funda en que el mismo legislador establezca -de manera expresa, en el contenido de una ley-, que un comportamiento suyo genera responsabilidad.

Sobre el particular, Ruiz Orejuela (2008: p. 4) advierte:

Es curioso cómo la responsabilidad 'legislativa' estaba limitada a los supuestos de responsabilidad prescritos en la misma ley, pero la derivada de los actos del poder ejecutivo - judicial por ejecución de una ley 'antijurídica', no requería supuestos legales predeterminados para su declaración.

Sin embargo, la Ley de Responsabilidad Patrimonial del Estado fue declarada inconstitucional desde el punto de vista formal -por el Tribunal Constitucional alemánmediante sentencia del 19 de octubre de 1982 (Embid Irujo, 1982: pp. 353-381; Sainz Moreno, 1982: pp. 381-393).

Hasta este momento, en el derecho alemán no se ha presentado ningún caso en el que se haya reconocido indemnización alguna con fundamento en la teoría de la responsabilidad patrimonial derivada de la actividad del Legislador. Así, H. J. Papier ha señalado: "(...) De modo que una eventual indemnización impuesta al Legislador debe reservarse al Legislador mismo" (García de Enterría, 2007: p. 162).

No obstante, a través del tiempo, la tradición jurisprudencial germana ha mostrado que las bases sobre las cuales descansa dicha ley, otorga una carga resarcitoria al Estado

\footnotetext{
${ }^{6}$ En la ley de 21 de diciembre de 1970 -de modificación del Tribunal Constitucional alemán, junto a la declaración de nulidad ('Erklärung der Nichtigkeit')- se introdujo la "declaración de incompatibilidad" ('Erklärung der Unvereinbarkeit), equivalente a la empleada por la Corte Constitucional colombiana de inexequibilidad o inconstitucionalidad.
} 
por los actos del legislador, lo cual sigue siendo -hasta nuestros días-, fundamento de imputación de responsabilidad patrimonial del Estado.

Adicionalmente, es pertinente indicar que no se prevén en el derecho alemán otros eventos, ni en la doctrina, ni en la jurisprudencia, que ilustren la responsabilidad del Estado en los actos del legislador, pero este avance en el tema resulta de gran importancia puesto que apunta unas directrices que pueden conducir a la construcción de una satisfactoria teoría de la responsabilidad patrimonial del Estado por los actos del legislador.

Finalmente, la jurisprudencia alemana niega cualquier relación entre la ley y la responsabilidad por daños, que se ha hecho especialmente visible en el Derecho Comunitario, por cuanto se ha venido a imponer responsabilidades patrimoniales a los Estados por leyes que infringen normas que en el Derecho Comunitario garantizan derechos patrimoniales individuales (Alonso García, 1999: p. 163; García de Enterría, 2007: p. 162; Peña Mateus, 2013: p. 45).

\subsection{ESPAÑA}

Antes de la Constitución de 1978, el planteamiento sobre la existencia de la responsabilidad del Estado Legislador fue prácticamente nula. En efecto, la Constitución española de 1931 -en el artículo 106- preveía una restricta responsabilidad estatal: "Todo español tiene derecho a ser indemnizado de los perjuicios que le irroguen por error judicial o delito de los funcionarios judiciales en el ejercicio de sus cargos, conforme determinen las leyes. El Estado será subsidiariamente responsable de estas indemnizaciones".

En cambio, la Constitución española de 1978 elevó a rango constitucional la fórmula de responsabilidad de naturaleza objetiva de las Administraciones Públicas, cuando en su artículo 106.2 consagra: "Los particulares, en los términos establecidos por la ley, tendrán derecho a ser indemnizados por toda lesión que sufran en cualquiera de sus 
bienes y derechos, salvo en los casos de fuerza mayor, siempre que la lesión sea consecuencia del funcionamiento de los servicios públicos".

Asimismo, la Carta Fundamental española de 1978, estableció en el artículo 121 la responsabilidad del poder judicial para los casos de error judicial o anormal funcionamiento de la Administración de Justicia. Pero la novedad más importante fue la proclamación realizada por el artículo 9.3, que consagró directamente el derecho que tienen los ciudadanos a ser indemnizados por los daños y perjuicios antijurídicos producidos por los poderes públicos, como garantía general de la responsabilidad de los poderes públicos que tiene un valor normativo directo, sirviendo para estructurar, junto con otros, todo el sistema jurídico-político del Estado (García-Álvarez, 2009: p. 1181).

En España, en virtud del marco constitucional descrito, está muy claro para la doctrina que el legislador debe ajustarse en sus prescripciones a los mandatos constitucionales (Cazorla Prieto, 1985: p. 53), puesto que el poder legislativo no es soberano ni omnipotente $y$, por lo tanto, los ciudadanos deben estar protegidos de la arbitrariedad del poder público.

De esta manera, dentro del escenario jurídico-constitucional descrito, el legislador español expidió el Régimen Jurídico de las Administraciones Públicas y del Procedimiento Administrativo Común, a través de la Ley 30/1992, de 26 de noviembre (modificada por la Ley 4/1999, de 13 de enero), que en el artículo 139.3 estableció la siguiente regla: "Las Administraciones Públicas indemnizarán a los particulares por la aplicación de los actos legislativos de naturaleza no expropiatoria de derechos y que éstos no tengan el deber jurídico de soportar, cuando así se establezca en los propios actos legislativos y en los términos que especifican dichos actos".

Sobre el particular, el tratadista español Celdrán Ruano (1996: p. 25) a su vez advierte: asentado, pues, en nuestro Ordenamiento, el régimen general de la Administración, con perfiles propios que lo distinguen del previsto para el Poder Judicial, la cuestión relativa a la responsabilidad del Estado Legislador procede de situarla en los términos previstos en el artículo 139.3 de la Ley 30 de 1992, reguladora de la responsabilidad que pudiera exigírsele 
al Estado (y también a las Comunidades Autónomas) como consecuencia de las lesiones a los particulares ocasionadas por las leyes.

Es de observar, sin embargo, cómo la norma bajo estudio restringe o limita drásticamente la reparación patrimonial a aquellos supuestos en que la propia ley que causa el daño especial y anormal la prevé, quedando descartada para los supuestos en que la ley que provoca el daño no contempla el resarcimiento. En suma, la responsabilidad del Estado Legislador por el dictado de una ley pasa a ser una cuestión de política legislativa que define libremente el propio legislador.

No obstante, las demandas judiciales por responsabilidad del Estado Legislador proliferaron, llegando al punto de que las sentencias condenatorias proferidas por el Tribunal Supremo español por responsabilidad del Legislador han superado en muy pocos años dos centenares. A raíz de ello, uno de los países que demuestra mayor desarrollo jurisprudencial en cuanto a la responsabilidad del Estado Legislador es España.

Así pues, la jurisprudencia española abrió la posibilidad de reclamar la indemnización de daños ocasionados por las leyes, en tres supuestos:

- En primer lugar, cuando el precepto legal causante del daño haya sido anulado por el Tribunal de Justicia de la Unión Europea, por ser contraria al Derecho de la Unión Europea, debido a que la responsabilidad de los Estados miembros de la Unión frente a los particulares de los daños y perjuicios derivados de las infracciones o el desconocimiento de los preceptos legales Comunitarios. Así, por ejemplo, la sentencia de 17 de septiembre de 2010 del Tribunal Supremo español inicia una línea jurisprudencial que denomina al principio de responsabilidad patrimonial del Estado 'cláusula de cierre' del sistema que regula las relaciones entre el Derecho comunitario y los Derechos internos, al conectar dicho principio con los de eficacia del ordenamiento comunitario y tutela judicial efectiva de los particulares (en el mismo sentido, la sentencia del 2 de octubre de 2012). 
Sin embargo, a principios del año 2012 comenzó a desarrollarse una jurisprudencia en la Sala de lo Contencioso-Administrativo del Tribunal Supremo español que cuestiona los pilares fundamentales del Derecho de la Unión, los reinterpreta, y todo ello con efectos siempre desestimatorios respecto de quien esgrime un derecho conferido por el ordenamiento europeo, tal y como acontece, entre otras, con las sentencias de 18 de enero y de 5 de marzo de 2012, en las cuales se incurre en un error, pues no es necesario que el Tribunal de Justicia se pronuncie para que un juez nacional constate la existencia de una "infracción suficientemente caracterizada", de la misma manera que, una vez declarada la misma por el Tribunal de Justicia, se trata de una infracción objetivizada desde el momento en que se dicta la sentencia y, por tanto, blindada a cualquier apreciación por parte del juez nacional (Sarmiento Ramírez-Escudero, 2012: pp. 10 y ss.).

- En segundo término, en el marco del Derecho interno español, también puede exigirse ante la jurisdicción contencioso-administrativa la responsabilidad del Estado Legislador por la declaratoria de inconstitucionalidad de una determinada Ley, decretada por el Tribunal Constitucional español, por violación de la Constitución de 1978.

Este supuesto de responsabilidad del Estado Legislador presenta ciertas semejanzas con la responsabilidad proveniente del incumplimiento del Derecho de la Unión Europea, y tiene lugar cuando el Tribunal Constitucional declara la inconstitucionalidad de una norma con rango de ley, de cuya aplicación se han ocasionado, a una persona, perjuicios valorables económicamente.

En principio, la inexequibilidad de una determinada Ley no conlleva 'per se' la extinción de las situaciones jurídicas creadas a su amparo ni el deber de indemnizar los daños ocasionados con su aplicación. Los efectos de la declaratoria de inconstitucionalidad de la Ley serán lo que, en su caso, determine la propia sentencia del Tribunal Constitucional; no obstante, en aquellas situaciones en las cuales la providencia no se pronuncia sobre el particular, la jurisprudencia admite 
que, declarada la inconstitucionalidad de una Ley, puede generarse responsabilidad patrimonial si ocasiona privación o lesión de bienes, derechos o intereses jurídicamente tutelados (Galán Vioque, 2001: pp. 289 y ss.; García de Enterría, 2007: pp. 134 y ss.; Garrido Mayol, 2004: pp. 172 y ss.; Navarro Fernández, 2010: T. II: pp. 123 y ss.; Xiol Ríos, 2007: pp. 1039 y ss.).

Pues bien, las sentencias que abren paso a la categórica recepción de la responsabilidad patrimonial del Estado Legislador por parte del Tribunal Supremo español, mantienen relación directa con la declaración de inconstitucionalidad de normas tributarias. Ciertamente, el Tribunal Constitucional español, con sede de Amparo, mediante la sentencia 45/1989 inauguró la doctrina según la cual aquellos contribuyentes que previamente a la declaración de inconstitucionalidad de una ley tributaria hubieren intentado recurso en contra del acto administrativo de cobro, con tal de que su resolución estuviese pendiente a la época de la sentencia del juez constitucional, se verían favorecidos por la declaratoria de inconstitucionalidad y, por tanto, las sentencias definitivas de los procesos en curso deberían considerar que la ley fue expulsada del ordenamiento jurídico, con lo cual la obligación tributaría se vería extinguida. 'Contrario sensu', quienes no hubieren presentado recurso, o cuyo recurso ya hubiera sido fallado, no podrían beneficiarse de la sentencia del Tribunal Constitucional.

Durante el tiempo de aplicación del criterio adoptado por la sentencia 45/1989, los efectos descritos de tal providencia fueron duramente criticados por la doctrina, la cual ironizando sostuvo que el Tribunal Constitucional estaba premiando a los recurrentes oportunos (Checa González, 2004: p. 56; Oliva Santos, 1989: p. 1197 y ss.); de ahí que el Tribunal Supremo reaccionara contra ella, propiciando y posibilitando un camino para obtener la restitución de lo ingresado con infracción de lo establecido por la propia Constitución española, al señalar al respecto que es factible el ejercicio de la acción de responsabilidad patrimonial derivada de un acto legislativo que haya sido declarado inconstitucional, inclusive en el supuesto de que el proceso hubiese ya terminado, añadiendo que la eficacia de la cosa juzgada no 
es óbice para el ejercicio de tal acción, lo que conlleva, en definitiva, el pleno reconocimiento de que existiendo un perjuicio individualizado, concreto y claramente identificable, debe procederse a su reparación (Checa González, 2004: p. 57).

De este modo, puede afirmarse que tres han sido fundamentalmente las decisiones del Tribunal Supremo, que en España abrieron el camino para el reconocimiento amplio del deber del Estado de indemnizar los daños producidos por una Ley declarada inconstitucional, incluso cuando la sentencia estimativa no tenga efectos retroactivos: la de 29 de febrero de 2000, y las de 13 de junio y 15 de julio del mismo año. A partir de ellas se concretó el reconocimiento de una acción jurisdiccional para reclamar la indemnización de perjuicios, que debe ser conocida por la magistratura competente según las reglas generales para resolver acciones patrimoniales en contra del Estado, y que ha de tener como antecedente necesario la declaración de inconstitucionalidad de la norma legal que es causa directa del perjuicio alegado por el demandante. Tales daños deben ser antijurídicos en razón de su inconstitucionalidad. Justamente, en las tres providencias citadas, los demandantes son contribuyentes que abonaron sumas en arcas fiscales por concepto de tributos posteriormente declarados inconstitucionales.

En efecto, en la sentencia de 29 de febrero de 2000, se reconoció el derecho a indemnización de un contribuyente que había agotado todas las instancias de impugnación del cobro; entre tanto, en el proveído del 13 de junio de 2000 se extendió este derecho a un demandante que no había efectuado las gestiones tendientes a la impugnación del cobro y, a su turno, la sentencia del 15 de julio de 2000 sistematizó la doctrina expuesta en las providencias anteriores, concluyendo el Tribunal Supremo español:

(...) Quienes han tenido que satisfacer el gravamen complementario, impuesto por el precepto declarado inconstitucional, después de haber impugnado por vía administrativa y sede jurisdiccional dicho gravamen, obteniendo sentencia firme que lo declara conforme a derecho, no tienen otra alternativa, en virtud de lo dispuesto por el artículo 40.1 de la Ley Orgánica 2/1979, del Tribunal Constitucional, que ejercitar, como en este caso ha procedido la entidad demandante, una acción por responsabilidad patrimonial, derivada del acto del legislador, dentro del plazo fijado por ley. 
De este modo, la jurisprudencia en comento del Tribunal Supremo adoptó la consiguiente posición: si no se hubieran impugnado jurisdiccionalmente las liquidaciones del correspondiente gravamen complementario, los interesados tienen a su alcance la vía de pedir, en cualquier momento, la revisión de tal acto nulo de pleno derecho, como prevé el art. 102 de la Ley 30/1992, y, coetánea o sucesivamente, de no tener éxito dicha revisión, están legitimados para deprecar la responsabilidad patrimonial emanada de actos del legislador, pero también pueden utilizar directamente esta acción, ya que no cabe imponer a quien ha sufrido un daño antijurídico la vía previa de la revisión de disposiciones y actos nulos de pleno derecho, a fin de dejarlos sin efecto, y sólo subsidiariamente permitirle demandar la reparación o indemnización compensatoria por responsabilidad patrimonial, cuando son las propias Administraciones quienes deben proceder a declarar de oficio la nulidad de pleno derecho de tales disposiciones o actos, y el ciudadano descansa en la confianza legítima de que la actuación de los poderes públicos se ajusta a la Constitución y a las leyes (Núñez Leiva, 2011: pp. 219-222).

Por otra parte, en las mencionadas sentencias se consolidó la tesis de la subordinación plena del legislador a la Constitución. Así, verbigracia, el Tribunal Supremo español en la providencia del 29 de febrero de 2000 esgrime el valor normativo de la Constitución ante el legislador y de la tajante ilegitimidad en que se halla envuelta una norma de tal tipo que vulnera el programa definido por la Carta Fundamental. De este modo, en el citado proveído en el Fundamento de Derecho cuarto aduce:

La Ley declarada inconstitucional encierra en sí misma, como consecuencia de la vinculación más fuerte con la Constitución, el mandato de reparar los daños y perjuicios concretos y singulares que su aplicación pueda haber originado (...) Existe una notable tendencia en la doctrina y en el derecho comparado a admitir que, declarada inconstitucional una ley, puede generar un pronunciamiento de reconocimiento de responsabilidad patrimonial cuando aquella ocasione, privación o lesión de bienes, derechos o intereses jurídicos protegibles. (...) El poder legislativo no está exento de sometimiento a la Constitución y sus actos -las leyes- quedan bajo el imperio de tal norma suprema. En los casos donde la ley vulnere las Constitución, evidentemente el Poder Legislativo habrá conculcado su obligación de sometimiento, y la antijuridicidad que ello supone traerá consigo la obligación de indemnizar. 
Entretanto, la sentencia dictada por la misma magistratura el 13 de junio de 2000, destaca en el Fundamento de Derecho cuarto que:

La determinación del título de imputación para justificar la responsabilidad del Estado Legislador por inmisiones legislativas en la esfera patrimonial (que ha vacilado entre las explicaciones que lo fundan en la expropiación, en el ilícito legislativo y en la teoría del sacrificio, respectivamente), ofrece así una especial claridad en el supuesto de ley declarada inconstitucional.

La sentencia del 15 de julio de 2000, a su turno, ofrece un contundente e inapelable reparo a la defensa de la fuerza vinculante de una ley contraria a la Constitución. Ciertamente, en el Fundamento de Derecho primero, para concluir que las prestaciones impuestas por una norma declarada inválida no generan obligación alguna, sino por el contrario deben ser resarcidos los afectados.

La experiencia española da cuenta de que de la confluencia de sentencias estimatorias de inconstitucionalidad -sin efecto retroactivo, con un principio general de responsabilidad del Estado y en sistemas con una Constitución plenamente normativa-, el resultado que se produce es el reconocimiento del deber reparatorio del Estado por los actos del legislador, contrarios a la Constitución, que afecten derechos fundamentales.

Pues bien, como supuestos en los que el Tribunal Supremo español ha reconocido derecho a indemnización cuando la Ley causante del daño hubiera sido declarada inconstitucional, pueden citarse, verbigracia, en relación (i) con un gravamen complementario en materia de tasa sobre los juegos de azar (sentencias de 14, 19, 22, 23 y 27 de diciembre de 2000); (ii) con los daños irrogados por el pase en situación de segunda actividad de los miembros del Cuerpo Nacional de Policía (sentencia del 17 de julio de 2003); (iii) con las reclamaciones fundamentadas en la declaración de inexequibilidad de la Disposición Adicional $4^{\text {a }}$ de la Ley de Tasas y Precios Públicos de 1989 (sentencia de 18 de septiembre de 2003); (iv) con los daños provenientes del pago de tarifas portuarias en aplicación del artículo 70.1 y 2 de la Ley 27/1992, de Puertos del Estado y de la Marina Mercante (sentencia de 18 de enero de 2011), y (v) con los daños ocasionados por la aplicación del Real Decreto-Ley 5/2002 de 24 de mayo, de medidas urgentes para la reforma del 
sistema de protección de desempleo y la mejora de ocupabilidad (sentencia de 18 de enero de 2011).

Sin embargo, la posibilidad de solicitar indemnización por los daños derivados de la declaratoria de inconstitucionalidad de una Ley se hace nugatoria, cuando es la propia providencia del Tribunal Constitucional la que establece, por motivos de seguridad jurídica, que sus efectos se produzcan solamente hacia el futuro. El Tribunal Constitucional español ha hecho uso con cierta frecuencia de esta posibilidad considerando que "más allá de la consecuencia inmediata de la declaración de nulidad, esto es, la inaplicación a nuevos supuestos, el Tribunal Constitucional debe ponderar qué consecuencias adicionales puede contener la declaración de nulidad para evitar que resulten injustificadamente perjudicados otros bienes constitucionales" (sentencia 54/2002). El principio que se invoca es el de seguridad jurídica, empero en ocasiones se depreca la protección de la Hacienda pública ante unas indemnizaciones que podrían resultar excesivas (sentencias 45/1989; 179/1994; 185/1995; 194 y 289/2000; 193/2004 y 295/2006).

- El tercer supuesto de responsabilidad del Estado Legislador deviene cuando una Ley no declarada inconstitucional y en armonía con el Derecho de la Unión Europea, produce daños singularizados y evaluables económicamente a un sujeto de derecho. Para estos supuestos, el artículo 139.3 de la Ley 30/1992 contempla dos situaciones distintas, según la Ley tenga o no naturaleza expropiatoria.

En primera medida, si la Ley tiene naturaleza expropiatoria, deberá indemnizarse a los expropiados, debido a que toda ley singular expropiatoria debe respetar las garantías esenciales del artículo 33.3 de la Constitución española de 1978 y, por lo tanto, el pago del justiprecio (Tribunal Constitucional, sentencias 111/1983 y 166/1986). En este sentido, el Tribunal Supremo español en la sentencia del 2 de junio de 2010, descarta, en primer lugar, que la condición o presupuesto que impone el inciso final del art. 139.3 de la Ley 30/1992, al señalar: especifiquen dichos actos, resulte de aplicación a los supuestos de acciones de 
responsabilidad patrimonial sustentadas en el perjuicio irrogado por la aplicación de una ley inconstitucional al concluir que ello (...) supondría tanto como supeditar la reparación del hipotético perjuicio derivado de la inconstitucionalidad de la ley aplicada, a una previsión que en sí misma es absurda e incluso imposible: la del propio legislador de prever que la ley que aprueba puede ser contraria a la Constitución y de que por ello, por si lo fuera, ha de plantearse si incluye o no en ella una decisión como la reflejada en aquel inciso final y considera que tal conclusión es la que está presente en la jurisprudencia del mismo Tribunal (sentencias 29 de febrero, 13 de junio y 19 de diciembre de 2000).

En segundo lugar, en el evento de que la Ley no tenga naturaleza expropiatoria, el artículo 139.3 de la Ley 30/1992 establece la indemnización a favor de los particulares cuando no tengan el deber jurídico de soportar el daño. En torno a la regulación española, una de las cuestiones que han surgido en su jurisprudencia ha sido cómo discernir entre lo que merezca ser calificado de expropiación, según la norma descrita, la cual sólo se admite en virtud de causas determinadas (utilidad pública e interés social) y mediante indemnización, y lo que la propia norma califica como delimitación del contenido de la propiedad, que es una compensación legislativa ordinaria y que no requiere ser indemnizada (García de Enterría, 2005: p. 189).

De esta manera, en la doctrina española se puede observar una cierta confusión entre la responsabilidad por leyes y expropiaciones legislativas (Quintana López, 1994: pp. 125-126). Un grupo de administrativistas encabezado por García de Enterría y Garrido Falla, han sostenido que en el ordenamiento jurídico español, en el que está establecida la garantía expropiatoria del derecho de propiedad en el artículo 33 de la Constitución española, todas las lesiones patrimoniales que sufran los particulares como consecuencia de la aplicación de una disposición legal tienen un único cauce indemnizatorio, las denominadas expropiaciones 'ope legis'. Si una ley es materialmente expropiatoria tendrá necesariamente que incluir una cláusula indemnizatoria (Barnés Vásquez, 1995: p. 143), la conocida 'juntim Klausel' alemana para evitar su declaración de inconstitucionalidad. Además, el concepto de expropiación forzosa se convierte así en el concepto clave para establecer cuándo debe indemnizar el Estado en el ejercicio de su potestad legislativa. 
Frente a esta posición, Muñoz Machado (1993: p.117) ha señalado que pretender subsumir la reparación de todos los daños legislativos en la figura de las expropiaciones legislativas, resulta inaplicable. El autor indica que el problema radica en la falta de configuración de los límites de un derecho o de las condiciones precisas de su ejercicio, lo cual lo conduce a concluir que, ante la existencia de perjuicios legislativos, acudir a las reglas del derecho de la responsabilidad civil extracontractual y no a las de las expropiaciones parece ser un camino inevitable.

Ahora bien, la legislación española muestra de forma diáfana que un presupuesto inexcusable para la prosperabilidad de la pretensión indemnizatoria es que el particular "no tenga el deber jurídico de soportar" la lesión producida por la aplicación del acto legislativo. Tal requisito se encuentra descrito en el artículo 139.3 de la Ley 30/1992 y vuelve a reproducirse como exigible en el art.141.1 del mismo cuerpo normativo, al consagrarse que "sólo serán indemnizables las lesiones producidas al particular provenientes de daños y que éste no tenga el deber jurídico de soportar de acuerdo con la ley".

Se insiste por el Tribunal Supremo (sentencia del 18 de enero de 2011) que "existe ese deber jurídico de soportar el daño cuando la medida de la administración constituye una carga de carácter general que todos los administrados incluidos en el ámbito de dicha medida están obligados a cumplir sin indemnización".

Al respecto, el mismo Tribunal (sentencia del 16 de diciembre de 2008), invocando el artículo 139.3 de la ley 30/1992, con referencia a las vías de indemnización contempladas en la misma, siguiendo la doctrina según la cual en el derecho Español se admite la existencia de una responsabilidad patrimonial a cargo del Estado por razón de actos legislador, siempre que se den los siguientes requisitos:

El fundamento de la responsabilidad a que hace referencia no radica en el art. 33 de la constitución sino en su art.9.3, que impone el principio de seguridad jurídica; el fundamento no radica en la privación o limitación conforme a la constitución de derechos preexistentes, sino en la frustración de meras expectativas, que en los casos y en la forma que exige la teoría y doctrina invocada son indemnizables; que exige el establecimiento y 
regulación de la misma por una ley; que dicha regulación en sentido formal queda radicada por el art.193.3 de la Ley 30/92; y concluye que tal exigencia y existencia de responsabilidad patrimonial del Estado por sus casos legislativos, es procedente en el caso de alteraciones del régimen jurídico del ejercicio de profesiones liberales, invoca la doctrina de la sentencia de 5 de junio de 1997 entendiendo que reconoce la indemnización de los perjuicios causados en derechos consolidados si estuviera en vigor el art.139.3 de la Ley 30/92, la sentencia de 18 de julio de 1997 para señalar que la cuestión resuelta por los tribunales sobre la edad de jubilación de los funcionarios no es equiparable al ejercicio de profesionales liberales, la sentencia de 2 de diciembre de 1992 para indicar que su doctrina está superada y, finalmente, la sentencia de 11 de febrero de 1999, para concluir que, cuando mediante medidas legislativas se imponen limitaciones al ejercicio de las profesiones liberales, no se están eliminando meras expectativas, sino auténticos derechos consolidados, que en la mayoría de los casos ha supuesto a los profesionales un gran coste de infraestructuras materiales y humanas, actuando sobre la confianza en la no alteración futura de las circunstancias y el Estado, sin otro fundamento que el simple capricho, cercena tales derechos y rendimientos económicos futuros, quedando obligado a indemnizar.

Según esta descripción, el supuesto de responsabilidad del Estado Legislador derivado del artículo 139.3 de la ley 30/1992, lo ha fundamentado el Tribunal Supremo español principalmente en el principio de la confianza legítima ${ }^{7}$ (sentencia del 23 de diciembre de 2010). Este principio de confianza legítima es objeto de análisis por parte del Tribunal Supremo, que en sentencia reciente precisó que la quiebra de dicho principio se muestra como el eje sobre el que gira el examen de las circunstancias concurrentes en cada caso para determinar si hay o no justificación para soportar el daño causado.

Así pues, sobre el sometimiento del legislativo a la constitución, el Tribunal (sentencia de 24 de febrero de 2010) puntualizó:

Avanzando en los requisitos exigibles para que pueda prosperar una pretensión de responsabilidad patrimonial se ha de examinar la concurrencia o no de la antijuridicidad, afirmada por la sala de instancia, mas rechazada por la parte recurrente en casación. Partimos de que el artículo 139 de la Ley 30/1992 expresa en su apartado 3 que 'las administraciones públicas indemnizarán a los particulares por la aplicación de actos legislativos de naturaleza no expropiatoria de derechos, y que estos no tengan el deber jurídico de soportar, cuando así se establezca en los principios actos legislativos y en los términos que especifiquen dichos actos'. Sin perjuicio de que la norma no hubiere establecido nada, ni tampoco hubiere establecido nada, ni tampoco hubiere habido pronunciamiento del Tribunal Constitucional enjuiciado su eventual inconstitucionalidad (sentencia del Tribunal Supremo de 10 de diciembre de 2009 recurso de casación 634/2008), hemos de partir de que esta sala desde su sentencia de 29 de febrero de 2000 , recurso de casación 49/1998, ha venido manteniendo que aunque la ley no declare nada sobre dicha responsabilidad, los tribunales pueden indagar la voluntad tácita del legislador,

\footnotetext{
7 El principio de la confianza legítima es procedente del Derecho alemán, en cuya jurisprudencia ordinaria y constitucional se formó, y de donde pasó a la jurisprudencia del Tribunal de Justicia de las Comunidades Europeas, aunque con nuevas matizaciones, y de aquí, con una notable precocidad, además de una resolución sorprendente, a la jurisprudencia del Tribunal Supremo español, que inmediatamente pasó a aplicarlo a la justificación de la responsabilidad patrimonial del Legislador (García de Enterría, 2007: pp. 33-34).
} 
en cuanto que le poder legislativo no está exento de sometimiento a la constitución y sus casos quedan bajo el imperio de aquella.

La jurisprudencia del Tribunal Supremo español, que ha comenzado en las últimos dos décadas a declarar con cierta normalidad una responsabilidad patrimonial como consecuencia de Leyes formales, ha creído encontrar en el principio de protección de la confianza legítima (que la jurisprudencia comenzó por influjo del Tribunal de Justicia de las Comunidades Europeas) un fundamento explícito para justificar dicha extensión de la responsabilidad. Así, por ejemplo, se encuentran las sentencias de 5 de marzo de 1993, 27 de junio de 1994 y 16 de diciembre de 1997 del Tribunal Supremo español, las tres referentes a perjuicios ocasionados a empresas pesqueras por el Tratado de Adhesión de España a las Comunidades Europeas, adhesión que fue autorizada por la Ley Orgánica 10 del 2 de agosto de 1985.

El principio de confianza legítima tiene en España rango constitucional, como una concreción del principio de seguridad jurídica (García Luengo, 2001: pp. 183-189; Castillo Blanco, 1998: pp. 97 y ss.), el cual se encuentra proclamado específicamente por el artículo 9.3 de la Constitución española de 1978.

Además, en sentencia del 30 de junio de 2001 se cita como especialmente relevante entre otros criterios-, el principio de buena fe en las relaciones entre el Estado y los particulares y el de seguridad jurídica, aduciendo que estos conceptos

(...) están estrechamente relacionados con el principio de confianza legítima, enunciado por el Tribunal de Justicia de las Comunidades Europeas. Se enuncia que esa jurisprudencia obliga a responder en el marco comunitario de la alteración (sin conocimiento anticipado, sin medidas transitorias suficientes para que los sujetos puedan acomodar su conducta económica y proporcionadas al interés público en juego, y sin las debidas medidas correctoras o compensatorias de las circunstancias económicas habituales y estables generadoras de esperanzas fundadas de mantenimiento), empero luego que el principio no garantiza a los agentes económicos la perpetuación de la situación existente (...) ni les reconoce un derecho adquirido al mantenimiento de una ventaja.

En esta situación la teoría de la responsabilidad del Estado Legislador suministraba una herramienta llamativa a los litigantes y a los tribunales, debido a que posibilitaba la reparación de los daños causados por una ley sin afectar a la validez de ésta. 


\subsection{ITALIA}

En Italia, de manera similar a lo acontecido en el sistema jurídico alemán, positivamente no se encuentra consagrada la responsabilidad del Estado Legislador, pero la doctrina ha desarrollado la tesis sobre la expropiación, el ilícito legislativo y la teoría del sacrificio. Asimismo, no hay ningún pronunciamiento judicial de responsabilidad patrimonial del Estado Legislador.

Sin embargo, Galán Vioque (2001) ha incluido al italiano entre los ordenamientos jurídicos que reconocen una responsabilidad ordinaria por actos legislativos. En efecto, la Constitución italiana de 1947 (que entró en vigor en 1948), en el tema de la Responsabilidad por daños parece limitar con toda claridad el deber resarcitorio del Estado a los supuestos de ilícitos cometidos por funcionarios de la Administración, excluyendo toda Responsabilidad derivada de la propia ley.

De esta manera, la doctrina italiana ha efectuado una distinción entre dos tipos de leyes: las que regulan la conducta de los particulares y de las cuales -si éstos no demandan su inconstitucionalidad-, la concurrencia de culpa entre el poder legislativo y el particular descarta cualquier indemnización, y las que establecen una sanción por su incumplimiento. En este último evento, el administrado -so pena de una consecuencia impuesta por la norma-, no puede rehusarse a su cumplimiento, y es aquí donde éste puede pretender el resarcimiento (Ruiz Orejuela, 2005: pp. 80-81).

Más recientemente, y con base en la teoría del sacrificio de los derechos privados, se ha puesto sobre la mesa la cuestión de si el legislador se halla vinculado constitucionalmente a resarcir los daños que causa a los particulares por el uso de su potestad normativa. La respuesta a este interrogante es hoy unánimemente positiva, si bien condicionada a la existencia de un auténtico y verdadero sacrificio.

Para mayor claridad, el referente judicial lo constituye la sentencia No. 7 de 1966 de la Corte Constitucional italiana, que establece un parámetro de interpretación, según el 
cual las leyes deben interpretarse en el sentido en que se reduzcan al máximo las contradicciones entre éstas y la Constitución, y su silencio frente a la indemnización por los perjuicios que su aplicación cause no es óbice para que la responsabilidad estatal sea declarada por los tribunales.

La Corte Constituzionale haciendo referencia al artículo 42 de la Constitución italiana que garantiza la propiedad, en la sentencia No. 252 de 1983 advirtió cómo

\begin{abstract}
la norma dicha no ha transformado, como se ha sostenido por una parte de la doctrina, la propiedad en una función pública (...) La Constitución claramente ha continuado en considerar la propiedad privada como un derecho subjetivo, pero ha confiado al legislador ordinario la misión de introducir, como consecuencia de las oportunas valoraciones y del necesario balance de intereses, aquellos límites que aseguran en ella la función social. Indudablemente, dicha función con el solemne reconocimiento que ha tenido en la Carta Fundamental, no puede ser considerada, como en el pasado, una mera síntesis de los límites ya existentes en el ordenamiento positivo con base en disposiciones singulares; representa, más bien, la orientación general que deberá inspirar la futura legislación (García de Enterría, 2007: p. 166).
\end{abstract}

Así entonces, en el panorama constitucional italiano, originariamente, no se admitió más que la figura de la expropiación legislativa ('ope legis').

\title{
4.5. UNIÓN EUROPEA
}

Al terminar la Segunda Guerra Mundial se presentan en Europa varios procesos de cooperación económica que no fracasan, puesto que permiten que más adelante se inicie la fase de integración económica, cuyos buenos resultados han ayudado a conducir la Unión Europea a un proceso de integración política.

Ciertamente, la integración europea se hizo realidad con la firma del Tratado constitutivo de la Comunidad Económica Europea -CEE (que ha evolucionado hasta convertirse hoy en la Unión Europea -UE de conformidad con el Tratado de Maastricht de 1992, firmado en Roma en marzo 25 de 1957 y que entró en vigor en enero $1^{\circ}$ de 1958). De esta suerte, la Unión Europea se basa en el Estado de Derecho, puesto que todas las acciones que emprende se basan en los tratados que han sido aprobados voluntaria y democráticamente por todos los Estados miembros (Castellot Rafful, 2000: pp. 48 y ss.). 
Asimismo, en esas fechas también se firmó y entró en vigor el Tratado sobre ciertas instituciones comunes, en concreto la Asamblea (futuro Parlamento Europeo) y el Tribunal de Justicia (Mariño Menéndez, 1995: p. 14; Solís, 1995: pp. 15 y ss.). El Tribunal de Justicia de la Unión Europea-TJUE (antes de la entrada en vigor del Tratado de Lisboa, es decir, del $1^{\circ}$ de diciembre de 2009, se denominaba Tribunal de Justicia de las Comunidades Europeas -TJCE), posee la facultad jurisdiccional o poder judicial en la Unión, interpretando y aplicando el Derecho Positivo de la Unión Europea.

Por su parte, este Tribunal supranacional de Justicia ha señalado cómo el conjunto de Tratados de la Unión ha originado la creación de un nuevo ordenamiento jurídico comunitario, en virtud del cual,

los Estados han limitado, en ámbitos cada vez más amplios, sus derechos de soberanía (sentencia de 5 de febrero de 1963,26/62, y de 15 de julio de 1964,6/64), y cuyos sujetos no son únicamente los Estados miembros, sino también sus nacionales, y que al igual que impone cargas a los particulares, el Derecho comunitario también genera derechos que entran a formar parte de su patrimonio jurídico.

Tradicionalmente, el Tribunal de Justicia de la Unión Europea -TJUE ha realizado una interpretación muy amplia de los derechos y libertades de los ciudadanos de los Estados miembros (Segura Serrano, 2010: p. 237). En este sentido, la jurisprudencia de dicho corporación de justicia, ha contribuido de una manera extraordinaria al desarrollo del proceso de integración comunitaria, convirtiéndose en su verdadero propulsor (Garzón Clariana, 1993: p. 51).

De este modo, como indica Pérez González (2001: pp. 29 y ss.), la protección de los derechos que las normas comunitarias prevén a favor de los particulares cobra singular importancia en el sistema de la Unión Europea. La razón es de sobra conocida: el logro de los objetivos previstos en los Tratados sólo es posible si el Derecho de la Unión es respetado en todos los Estados miembros. Es sabido que se trata de un Derecho que se inserta en los ordenamientos jurídicos estatales (TJUE, sentencias de 15 de julio de 1964 y de 9 de marzo de 1978), y que debe ser aplicado por las autoridades de los Estados miembros. 
En efecto, la recepción e implantación en los Ordenamientos nacionales de las exigencias del Derecho de la Unión Europea, y la consiguiente pérdida de la autonomía estatal en beneficio de la supremacía de éste (Alonso García, 1999: p. 137), no es una cuestión novedosa y ajena al desenvolvimiento y aplicación de aquél.

De ahí la importancia del papel de los órganos jurisdiccionales internos. Con el objeto de que la labor de aplicación de las normas de la Unión se realice de manera uniforme, el Tribunal de Justicia de la Unión Europea ha guiado los pasos de los tribunales nacionales. Para ello, ha elaborado una serie de principios tendientes a lograr la protección judicial efectiva y uniforme de los derechos comunitarios de los particulares. El objetivo de esta línea jurisprudencial ha sido, en definitiva, asegurar que la efectividad de las normas comunitarias no fuese eliminada en la práctica por los tribunales de los Estados miembros (Pérez González, 2001: pp. 67 y ss.).

El más reciente de esos principios es el de responsabilidad del Estado miembro por los daños causados a los particulares por las violaciones del Derecho comunitario que le son imputables (Pérez González, 2001: pp. 67 y ss.). Este principio fue enunciado por primera vez en las sentencias proferidas el 19 de noviembre de 1991 -dentro de los asuntos "Francovich" y "Bonifaci" contra la República de Italia-, que declararon por primera vez en el ámbito europeo la responsabilidad patrimonial de un Estado miembro por violación del Derecho Comunitario (sentencias de 19 de noviembre de 1991, asuntos acumulados C-6/90 y C-9/90).

Muchos de los objetivos planteados al interior de la Unión son asignados a la Directiva como medio jurídico más idóneo para alcanzarlos. Así entonces, la sentencia "Francovich" en 1991 -en la que precisamente el Tribunal de Justicia supranacional atiende a un caso de incumplimiento de Estado miembro por la falta de transposición de una Directiva dentro del plazo concedido-, es el germen de un principio de responsabilidad de índole comunitaria, que ha venido a completar la armonía de la integración del ordenamiento de la Unión en los sistemas jurídicos nacionales, 
edificada desde los principios de primacía y efecto directo, con vistas a otorgar una efectiva protección de los derechos subjetivos de los 'justiciables' (Ruiz-Jarabo Colomer, 1997: pp. 121-133); en otras palabras una verdadera tutela judicial efectiva, puesto que el incumplimiento, por parte del Estado miembro, de la obligación de trasposición de una determinada directiva en el plazo fijado a tal efecto, supone que los particulares se vean desprovistos de los derechos que la norma comunitaria prevé en su favor (Pérez González, 2001: pp. 71 y ss.).

Asimismo, la decisión proferida para los casos planteados por Andrea Francovich y Danila Bonifaci, señaló que para poder determinar la posibilidad de reclamar una compensación por la no transposición de las normas comunitarias por parte de las autoridades de un Estado miembro, no es suficiente con la constatación de la violación del Derecho Comunitario, sino que se hace necesario, además que el resultado de la Directiva implique la atribución de derechos a favor de los particulares, y el contenido de esos derechos pueda ser identificado basándose en las disposiciones de la Directiva $y$, finalmente, que se estime la relación de causalidad entre el daño y la imputabilidad al Estado incumplido. Como todos estos supuestos se cumplieron en los asuntos descritos, los fallos del Tribunal de Justicia comunitario fueron estimatorios de las pretensiones de indemnización.

Desde la sentencia proferida en los casos "Francovich" y "Bonifaci", el Tribunal de Justicia de la Unión Europea ha ido configurando una doctrina jurisprudencial propia sobre la responsabilidad de los Estados miembros por incumplimiento del Derecho de la Unión Europea y, en particular, por la ausencia de transposición (casos acumulados "Francovich" y "Bonifaci") o por la incorrecta transposición de directivas (asunto "British Telecommunications", sentencia de 26 de marzo de 1996, caso C-392/93).

Igualmente, y de manera general, el Tribunal de Justicia de la Unión Europea ha establecido en su jurisprudencia la necesidad de la presencia de tres requisitos para que pueda concretarse la responsabilidad de un Estado miembro por infracción de Derecho Comunitario (asuntos acumulados C-6/90 y C-9/90-; "Brasserie du Pêcheur y 
Factortame", del 5 de marzo de 1996 --asuntos C-46/93 y 48/93-; "British Telecommunications", del 26 de marzo de 1996 -asunto C-392-; “Dillenkofer e.a.", del 8 de octubre de 1996 -asuntos C-178, 179 y 188/94-; y "Test Claimants in the Fll Group Litigation y Commissioners of Inland Revenue", del 12 de diciembre de 2006 -asunto C-446-04), a saber:

- Que la norma jurídica vulnerada por la ley estatal tenga por objeto conferir derechos a los particulares;

- Que exista un nexo de causalidad directa entre la infracción de la obligación que incumbe al Estado y el daño sufrido por el particular,

- Y que la violación de Derecho Comunitario por la Ley sea "suficientemente caracterizada, esto quiere decir, que cuando existe una imposición del Derecho de la Unión Europea de una obligación al Estado miembro, para cuyo incumplimiento no tiene la posibilidad de apreciación de clase alguna, o también, cuando el Estado miembro goza de un margen de discrecionalidad, pero infringe, manifiesta y gravemente, los límites impuestos en el ejercicio de sus facultades de apreciación.

Ahora bien, aunque el Tribunal de Justicia de la Unión Europea ha perfeccionado desde la sentencia Francovich las premisas y los requisitos que han de darse como supuestos de hecho para la exigencia por los particulares de responsabilidad al Estado, no ha de marginarse en absoluto el papel que siguen jugando los sistemas internos de responsabilidad tanto desde una perspectiva sustantiva como procesal,

debido a que el régimen supranacional constituye un estándar mínimo activado formalmente conforme a las reglas nacionales -enmarcadas, eso sí, en un exigido contexto comunitario de efectividad e igualdad de tratamiento con relación a situaciones puramente internas-; a lo que debe añadirse (...), la constante incidencia de los sistemas nacionales en la evolución del propio sistema comunitario (Martín Queralt, 2008: p. 94).

Ello es lógico y es además expresión de la cláusula de colaboración o de "buena fe" contenida en el artículo 10 del Tratado de la Comunidad Europea, según la cual 
los Estados miembros adoptarán todas las medidas generales o particulares apropiadas para asegurar el cumplimiento de las obligaciones derivadas del presente Tratado 0 resultantes de los actos de las instituciones de la Comunidad. Facilitarán a esta última el cumplimiento de su misión. Los Estados miembros se abstendrán de todas aquellas medidas que puedan poner en peligro la realización de los fines del presente Tratado.

En este orden de ideas, es importante resaltar que la Corporación de Justicia supranacional ha señalado que la obligación de los Estados miembros de reparar dichos daños se basa también en el artículo 4.3 del Tratado de la Unión Europea (antiguo art. 10 del Tratado de la Comunidad Europea), en virtud del cual los Estados miembros deben adoptar las medidas apropiadas para asegurar el cumplimiento de las obligaciones que les incumben en virtud del Derecho de la Unión. Entre esas obligaciones se encuentra la de eliminar las consecuencias ilícitas de una violación del Derecho de la Unión Europea; planteamiento que es válido ya se trate de normas invocables o no directamente por los ciudadanos ante los tribunales, como se precisó por el Tribunal de Justicia en las sentencias de 5 de marzo de 1996 (C-46/93 y C48/93).

Asimismo, la sentencia de 4 de julio de 2000 (TJUE, C-424/97) declara que incumbe a cada Estado miembro garantizar que los particulares obtengan la reparación del daño ocasionado por el incumplimiento del Derecho de la Unión, indistintamente del cual fuere la autoridad pública que haya incurrido en dicho incumplimiento y sea cual fuere aquella a la que, con arreglo al Derecho del Estado miembro afectado, le corresponda hacerse cargo de dicha reparación (TJUE, sent. de 1 de junio de 1999, C-302/97), puesto que el Estado que incurre en responsabilidad es considerado como una unidad, indistintamente que la infracción sea atribuible al poder administrativo, legislativo o judicial.

De otra parte, por lo que respecta a otros perjuicios sufridos por una persona por causa de una infracción del Derecho comunitario imputable a un Estado miembro, éste está obligado a reparar los daños causados a los particulares en las condiciones recogidas en el apartado 51 de la sentencia de 5 de marzo de 1996, "Brasserie du Pêcheur y Factortame" (C-46/93 y C-48/93), sin que esto excluya que, con arreglo al Derecho 
interno, el Estado miembro pueda incurrir en responsabilidad en virtud de requisitos menos restrictivos.

En definitiva, la elaboración y progresiva concreción en el seno del Tribunal de Justicia de la Unión Europea de un sistema que permite asegurar la reparación monetaria a cargo de los Estados miembros por los daños causados a los ciudadanos derivados del incumplimiento del Derecho europeo, al lado de la prevista para otorgar eficacia al principio de confianza legítima, puede llegar a significar una trascendente evolución para la teoría de la responsabilidad del Estado Legislador en los respectivos órdenes internos (Alonso García, 1999: p. 137).

\subsection{CHILE}

En este país austral, la responsabilidad del Estado se encuentra sustentada por una serie de principios constitucionales (supremacía formal-material, valor normativo y eficacia normativa) y legales, además de estar sustancialmente determinada su orientación al bien común, y al deber de respetar plenamente los derechos y garantías que la Carta Política consagra (Caldera Delgado, 1982: pp. 9 y ss.; Zúñiga Urbina, 2005: p. 68).

En efecto, en el ordenamiento jurídico chileno, la responsabilidad general del Estado en sus facetas de administrador, juzgador y legislador-, se encuentra consagrada en la propia Constitución Política de 1980, norma suprema y directamente aplicable, conforme a sus artículos $6^{\circ}$ y $7^{\circ}$, que establecen principalmente la aplicación directa de las normas constitucionales tanto a personas como órganos estatales, seguida de aplicación de sanciones en caso de que se genere responsabilidad por infracción a sus preceptos.

De la misma manera, el inciso final del artículo $5^{\circ}$ de la Carta Fundamental chilena señala: "El ejercicio de la soberanía reconoce como limitación el respeto a los derechos esenciales que emanan de la naturaleza humana"; de manera que dicha norma 
superior establece límites al ejercicio del Poder Público, el cual detenta la soberanía, esto es, la facultad de organización, de las atribuciones y del desarrollo o dinamización de las diversas potestades que integran aquélla (Caldera Delgado, 1982: p. 37).

Sin embargo, el rasgo esencial de la responsabilidad del Estado en la Constitución Política de Chile (1980), se encuentra caracterizado por la norma que establece, como principio general, que es indemnizable todo daño causado a un administrado o persona por la acción u omisión de cualquiera de los organismos del Estado.

Ciertamente, el artículo 38 inciso $2^{\circ}$ de la Carta Política chilena indica:

"Cualquier persona que sea lesionada en sus derechos por la Administración del Estado, de sus organismos o de las municipalidades, podrá reclamar ante los tribunales contenciosoadministrativos que determine la ley, sin perjuicio de la responsabilidad que pudiere afectar al funcionario que hubiere causado el daño".

A su turno, el inciso $26^{\circ}$ del artículo 19 constitucional asegura a todas las personas:

"La seguridad de que los preceptos legales que por mandato de la Constitución regulen o complementen las garantías que ésta establece, o que las limiten en los casos en que ella lo autoriza, no podrán afectar los derechos en su esencia, ni imponer condiciones, tributos o requisitos que impidan su libre ejercicio".

Pues bien, la forma en que se despliega en el texto constitucional chileno la responsabilidad del Estado, no está claramente definida, suscitando -derivadas de su aplicación-, una serie de interpretaciones tanto de la doctrina como de la jurisprudencia (Soto Kloss, 1996, T. II.: pp. 296 y ss.). Lo cual se refleja más claramente en la responsabilidad del Estado en su rol de legislador.

Sin embargo, el dogma de la infalibilidad y plenitud de la soberanía -o fetichismo de la ley, en el caso chileno-, se encuentra plenamente superado. Sabido es que el ejercicio de la soberanía reconoce como límite el respeto por los derechos esenciales que emanan de la naturaleza humana, sin distinción, pero guardando especial relevancia, en este caso los derechos de igualdad ante la autoridad, la ley, los tributos y las cargas públicas y los principios de buena fe, confianza legítima y seguridad jurídica (Núñez Leiva, 2010, ps. 193 y 194). Además, se presume que la actividad legislativa se halla sujeta a control de su adecuación a la Constitución. 
Empero, en Chile no existen antecedentes jurisprudenciales que se pronuncien efectivamente sobre la responsabilidad patrimonial del Estado Legislador. Con todo, cuatro sentencia son citadas de manera recurrente por la doctrina como ejemplos de eventuales indicios de la aplicación de esta teoría en dicho país. Se trata de los casos de la Comunidad Galletué contra el Fisco de Chile (Corte Suprema, sentencia del 7 de agosto de 1984, Rol N 16.743-1984), el de la Sociedad Agrícola Lolco Ltda contra el Fisco de Chile (Corte de Apelaciones de Santiago, sentencia de 31 de noviembre de 2003, Rol N 6828-1999), el de la Sociedad Inmobiliaria Maullín Ltda contra el Fisco de Chile (Tribunal Constitucional, sentencia de 18 de junio de 2004, Rol No 4309-2002) y, por último, el caso "Playas" (Tribunal Constitucional, sentencia de 2 de diciembre de 1996, Rol No 245-246/1996).

El primero de los casos descrito fue interpuesto ante un tribunal ordinario que, posteriormente, a través de recursos de casación y apelación, llegó a ser conocido por la Corte de Suprema de Chile; los dos siguientes trataban de recursos de inaplicabilidad presentados antes de la reforma constitucional del año 2005 y, el último, fue planteado ante el Tribunal Constitucional, a raíz de un requerimiento formulado por una minoría cualificada de diputados para la declaración de inconstitucionalidad del Decreto Supremo N ${ }^{\circ} 1$ de 1996, del Ministerio de Bienes Nacionales, fundado en que impone por vía decretal, limitaciones al derecho de propiedad de los dueños de terrenos colindantes de playas, de mar, ríos o lagos, sin mediar la correspondiente indemnización.

Si bien las decisiones descritas no reconocen expresamente estar en presencia de situaciones que generen responsabilidad para el Estado en su rol de legislador, presentan una serie de similitudes con las providencias judiciales proferidas sobre el particular en los ordenamientos jurídicos francés y español, en cuanto a criterios argumentativos. 
Así entonces, se asume que si bien es cierto las dos primeras sentencias condenaron al Fisco a pagar una compensación económica, no lo es menos que lo hicieron a causa de hechos del Estado nominador, en ejercicio de la potestad decretal, más no por actos del legislador. Lo cual constituyó un avance en la superación de la teoría de la doctrina del 'ius eminens'; no obstante, no es coincidente con las características que presenta el tema de la responsabilidad patrimonial del Estado Legislador.

En el tercer caso -el de la Sociedad Inmobiliaria Maullín Ltda contra el Fisco de Chile-, entretanto aborda el tema de los perjuicios provocados por la aplicación de una ley, pero no desde una perspectiva reparatoria de la intervención ablatoria del legislador, sino a parir de la inaplicabilidad por inconstitucional de normas preconstitucionales, el alcance del concepto de función social de la propiedad, el límite a las regulaciones del dominio y el concepto de "Regulatory Takings" (Núñez Leiva, 2010: pp. 188-189)

El caso "Playas", a su turno, interpreta las normas constitucionales en un sentido armónico y de acuerdo con los principios generales y los valores que inspiran el texto; el Tribunal Constitucional estimó que el Decreto Supremo $\mathrm{N}^{\circ} 1$ de 1996, al establecer la posibilidad de que se impusieran limitaciones al derecho de propiedad de los dueños de terrenos colindantes con playas a playas, de mar, ríos o lagos, sin mediar la correspondiente indemnización, atentaba claramente contra las disposiciones constitucionales y causaba daño, por lo cual debía acogerse el requerimiento planteado (Zúñiga Urbina, 2005: p. 124) .

\subsection{REFLEXIÓN}

En el Derecho Comparado, se puede apreciar cómo la teoría de la responsabilidad del Estado Legislador ha sido de creación jurisprudencial, estableciendo en cada país distintos regímenes y fundamentos de responsabilidad. Así, por ejemplo, en el ordenamiento jurídico de países como Francia y España, se presenta un admirable desarrollo tanto doctrinal y jurisprudencial en lo referente a la responsabilidad del Estado Legislador. 
A su vez, en el ordenamiento jurídico de muchos países aún no se ha logrado desarrollar o al menos consolidar la institución, como es el caso de Alemania y Chile. 


\section{LA RESPONSABILIDAD DEL ESTADO LEGISLADOR EN COLOMBIA}

\subsection{FUNDAMENTO CONSTITUCIONAL}

A todas luces, tanto las constituciones federales de mitad del siglo XIX, así como la Constitución Centralista de 1886, carecieron de una norma de base que sirviera de fundamento general a la obligación del Estado de indemnizar los perjuicios causados a los particulares. De este modo, tampoco existió una cláusula general que permitiera derivar -bien expresa o bien tácitamente-, la responsabilidad del Estado Legislador en Colombia.

Sin embargo, el vacío constitucional descrito no fue impedimento para que la jurisprudencia del Consejo de Estado encontrara el fundamento de dicha responsabilidad en distintas disposiciones de la Constitución de 1886, tales como los artículos 2으 16 y 30 , que consagraban el principio de legalidad, el deber del Estado de proteger la vida, honra y bienes de los ciudadanos y la garantía de la propiedad privada y de los demás derechos adquiridos con justo título (C.E., sentencia del 28 de octubre de 1976).

A su turno, la Carta Política de 1991 en el artículo 90, consagra la cláusula general de responsabilidad del Estado al señalar en su inciso primero: "El Estado responderá patrimonialmente por los daños antijurídicos que le sean imputables causados por la acción o la omisión de las autoridades públicas". Así, se elevaron a la categoría constitucional dos conceptos ya incorporados en el orden jurídico colombiano: el primero, por la doctrina y la jurisprudencia, como lo es el de la responsabilidad del Estado por los daños que le sean imputables, y, el segundo, por la ley que atañe a la responsabilidad de los funcionarios.

De este modo, el artículo superior bajo estudio, proporcionó un nuevo panorama normativo a la responsabilidad patrimonial del Estado, 
"puesto que al ligar la responsabilidad estatal a los fundamentos de la organización política por la que optó el constituyente de 1991, amplió expresamente el ámbito de la responsabilidad estatal, haciendo que ella desbordara el límite de la falla del servicio y se enmarcara en el más amplio espacio del daño antijurídico" (C. Const. Sent. C-285/02).

El artículo 90 de la Carta Política, atendiendo las construcciones jurisprudenciales, le proporcionó un nuevo enfoque normativo a la responsabilidad patrimonial del Estado, desplazando su fundamento desde la falla del servicio hasta el daño antijurídico. Ello implica la ampliación del espacio en el que puede declararse la responsabilidad patrimonial del Estado, pues el punto de partida para la determinación de esa responsabilidad ya no está determinado por la irregular actuación estatal -bien sea por la no prestación del servicio, por la prestación irregular o por la prestación tardía-, sino por la producción de un daño antijurídico que la víctima no está en el deber de soportar, independientemente de la regularidad o irregularidad de esa actuación (C. Const. Sent. C-285/02).

Esta concepción de daño antijurídico ha sido entendida por la jurisprudencia del Consejo de Estado en Colombia (C.E., sentencia del 13 de julio de 1993) como "la lesión de un interés legítimo, patrimonial o extrapatrimonial, que la víctima no está en la obligación de soportar", por lo cual "se ha desplazado la antijuridicidad de la causa del daño al daño mismo". Concluyó el Alto Tribunal: "el daño antijurídico puede ser el efecto de una causa ilícita, pero también de una causa lícita. Esta doble causa corresponde, en principio, a los regímenes de responsabilidad subjetiva y objetiva".

Al ser el daño antijurídico -el criterio fundamental en cuanto a la responsabilidad del Estado-, puede afirmarse que el mismo abarca las diferentes clases de responsabilidad, en la medida que todas ellas envuelven las actuaciones de la Administración en sus diferentes órdenes, pero que causan perjuicios a los administrados, en cuanto transgreden derechos igualmente legítimos, lo que deriva en el hecho de que solamente existirá obligación de reparar intereses que se encuentren en situación de legalidad, o sea, protegidos, puesto que de modo diferente, si el interés no es jurídicamente protegido, no podrá provenir reparación del daño. 
Así las cosas, la noción de daño en este caso parte de la base de que el Estado es el guardián de los derechos y garantías sociales, y que debe, por lo tanto, reparar la lesión que sufre la víctima de un daño causado por su gestión, porque ella no se encuentra en el deber jurídico de soportarlo.

\section{Pues bien, puede observarse cómo el precepto constitucional}

es no sólo imperativo -ya que ordena al Estado responder- sino que no establece distinciones según los ámbitos de actuación de las autoridades públicas. En efecto, la norma simplemente establece dos requisitos para que opere la responsabilidad, a saber, que haya un daño antijurídico y que éste sea imputable a una acción u omisión de una autoridad pública (C. Const., sentencia C-333/96).

En este orden de ideas, los criterios paulatinamente elaborados por la jurisprudencia contencioso-administrativa (C.E., sentencia del 8 de mayo de 1995) en materia de responsabilidad del Estado han recibido una expresión constitucional firme en el artículo 90, que representa entonces

la consagración de un principio constitucional constitutivo de la cláusula general de responsabilidad patrimonial del Estado, tanto la de naturaleza contractual como la extracontractual. Por ello, dicho precepto superior es el tronco en el que encuentra fundamento la totalidad de la responsabilidad patrimonial del Estado, trátese de la responsabilidad contractual o de la extracontractual.

No obstante, el artículo 90 no restringe la responsabilidad patrimonial del Estado al campo de su actividad administrativa, sino que consagra un régimen general, por lo cual dicha responsabilidad se refiere indistintamente a todas las autoridades públicas, lo cual incluye, en consecuencia, la actividad legislativa, pues no debe perderse de vista que uno de los pilares del Estado social y democrático de Derecho (art. 1ํㅡㄴ. Pol.) es el de que ninguna actividad estatal puede quedar exenta de control.

En efecto, como se ha señalado por la jurisprudencia de la Corte Constitucional (sent. 038/06), el artículo 90 de la Carta Política,

simplemente establece dos requisitos para que opere la responsabilidad patrimonial estatal, a saber, que haya un daño antijurídico y que éste sea imputable a una acción u omisión de una autoridad pública, sin hacer distingos en cuanto al causante del daño. De manera que la responsabilidad patrimonial del Estado por los hechos, acciones u omisiones imputables al Poder Legislativo está expresamente contemplada en el artículo 90 constitucional, pues cualquier otra posibilidad sería abiertamente inconstitucional desde la perspectiva del Estado Social de Derecho y de los principios y valores que rigen nuestro ordenamiento 
constitucional, tales como la solidaridad, la igualdad, la justicia material y la supremacía de la Constitución.

Sin embargo, es preciso advertir que la Carta Fundamental consagra expresamente determinados supuestos de obligación reparatoria por la actuación del Legislador, tales como la figura de la expropiación (art. 58), la obligación de indemnizar cuando se establece un monopolio (art. 336), o cuando el Estado decide reservarse determinadas actividades estratégicas o servicios públicos (art. 365).

Lo anterior no quiere significar que la responsabilidad del Estado Legislador se vea envuelta únicamente a los eventos anteriormente descritos, debido a que el fundamento de dicha responsabilidad gravita en la noción de daño antijurídico, la cual descansa en los principios de solidaridad y de igualdad, y no en la idea de la actividad ilícita del Legislador, entendida ésta como tal en las actuaciones contrarias a la Constitución (C. Const. sent. 038/06).

Ahora bien, el fundamento constitucional de la responsabilidad del Estado Legislador en Colombia no se encuentra circunscrito al artículo 90 superior, puesto que la responsabilidad patrimonial del Estado en nuestro ordenamiento jurídico tiene como fundamento un principio de garantía integral del patrimonio de los ciudadanos, consagrado además en los artículos 1, 2, 4, 6, 13, 58 y 95 de la Carta Fundamental, ampliamente desarrollado por vía jurisprudencial, y se configura por la concurrencia de tres presupuestos fácticos, a saber: un daño antijurídico o lesión, una actuación imputable al Estado y una relación de causalidad.

De este modo, el artículo $1^{\circ}$ de la Constitución de 1991 consagra a Colombia como un "Estado social y democrático de Derecho", fórmula que es la síntesis de tendencias históricas que reflejan la superación del esquema liberal tradicional, recogido en la expresión "Estado de Derecho". De la simple existencia de un control legal a la administración, y de la supremacía, suficiencia y autonomía del mercado como regulador de la sociedad civil, se ha pasado a un esquema en el cual toda actuación 
estatal (C. Const., sent. C-004/92) debe guardar armonía con la Carta Política, y dar lugar a la presencia de mecanismos que lo aseguren.

El carácter social de nuestro Estado de Derecho no es una fórmula retórica o vacía. Por el contrario, la naturaleza social que identifica al ordenamiento jurídico tiene clara expresión en la prevalencia de los derechos fundamentales, en la superación de la crisis del estado de derecho como sinónimo de la legalidad abstracta y en la inmediata realización de urgentes tareas sociales, todo lo anterior en desarrollo de los principios de solidaridad y dignidad humana (C. Const. Sentencia T-505/92).

Dichos principios son fundantes del Estado social de Derecho; por tanto, las situaciones lesivas de la dignidad de la persona repugnan al orden constitucional por ser contrarias a la idea de justicia que lo inspira. La reducción de la persona a mero objeto de una voluntad pública o particular, y los comportamientos que se muestran indiferentes ante la vulneración o amenaza de derechos fundamentales, son conductas que desconocen la dignidad humana y en tales casos pueden ser pasibles de condena por vía de las acciones legales correspondientes.

Así entonces, la Constitución Política signó a Colombia con un rasgo decididamente personalista, dado que en todos sus ámbitos y niveles reconoce la dignidad eminente de la persona humana y la primacía de sus derechos inalienables. En efecto, el Estatuto Superior establece "una nueva orientación filosófica que ubica al hombre en un lugar privilegiado y se convierte en el instrumento más eficaz al servicio de la dignificación del ser humano, lo cual se deduce de la lectura del Preámbulo y de los artículos 1 al 95" (C. Cons., sentencia T-571/92). Por su parte, la naturaleza social que identifica al Estado colombiano

asume una sentida connotación de prevalencia de los derechos fundamentales, en la superación de la crisis del Estado de Derecho y en la inmediata tarea de recuperación social en sus niveles, dentro de un necesario desarrollo de los principios de solidaridad y dignidad humana, los cuales orientan el nuevo Estado social de derecho (C. Cons., sentencia T499/92).

Por consiguiente, base fundamental de este esquema es el reconocimiento, entre otros valores, del respeto por la dignidad del ser humano, el cual debe inspirar todas las actuaciones del Estado, y constituye razón de ser, principio y fin último de la organización estatal. "El principio fundamental de la dignidad humana no sólo es una declaración ética sino una norma jurídica de carácter vinculante para todas las 
autoridades (C.P., art. 1ำ/ C. Const., sentencia T-499/92). De hecho, su consagración como valor fundante y constitutivo del orden jurídico "obedeció a la necesidad histórica de reaccionar contra la violencia, la arbitrariedad y la injusticia, en búsqueda de un nuevo consenso que comprometiera a todos los sectores sociales en la defensa y respeto de los derechos fundamentales" (C. Const., sentencias T-499/92, T-571/92).

Con fundamento en lo anterior, el respeto a la dignidad humana debe inspirar todas las actuaciones del Estado en sus diversas manifestaciones. En consecuencia, las autoridades están precisamente instituidas para proteger a toda persona en su vida, integridad física (salud), psíquica y espiritual, el mínimo de condiciones materiales necesarias para la existencia digna y patrimonio, puesto que son elementos constitutivos de una vida íntegra y presupuesto necesario para la autorrealización individual y social. "Un Estado insensible a las necesidades de los ciudadanos, no se compadece con sus fines esenciales, sino que al contrario, cosifica al individuo y traiciona los valores fundamentales del Estado social de derecho" (C.P., art. 1ㅇ / (C. Const., sentencia T-499/92).

Efectivamente, la dignidad de la persona es entendida como el punto de referencia que justifica y fundamenta la protección de todos los derechos fundamentales. Es claro cómo los derechos humanos, en tanto son expresión jurídica de la dignidad humana, están vinculados no sólo con todas las áreas del Derecho, sino con todos los campos de la actividad humana y de la convivencia social, en los que la dignidad del individuo pueda ser vulnerada o requiera de protección y tutela.

Tan clara opción en favor del ser humano, de su dignidad, y de sus derechos esenciales constituye un dictado para el legislador, a quien corresponde ajustar el sistema jurídico-legal a ese énfasis constitucional. Por lo tanto, el Estado tiene la obligación perentoria de instaurar, para tal propósito, un sistema legal ajustado a los preceptos esbozados en la Carta Fundamental, adoptando normas ajustadas a los preceptos superiores, orientadas a la protección de los derechos fundamentales de los administrados, cuando existan actos destinados a desconocerlos. La Constitución 
Política no sólo protege y salvaguarda los derechos fundamentales de los seres humanos, sino que, además, los incluye como un valor del ordenamiento, que implica competencias de intervención y deberes, para el Estado y para sus asociados, sin mirar excepciones de clase alguna para actividades o funciones de los actores involucrados.

Por su parte, del artículo $2^{\circ}$, inciso $2^{\circ}$, de la Constitución de 1991, se desprende que los fines del Estado consisten en irradiar sus actuaciones con el fin de promover la prosperidad general y garantizar la efectividad de los principios y deberes consagrados en el Estatuto Superior. Además, se establece que las autoridades de la República están instituidas para proteger a todas las personas residentes en Colombia, en su vida, honra, bienes, creencias, y demás derechos y libertades, y para asegurar el cumplimiento de los deberes sociales del Estado y de los particulares.

El artículo 4ํㅗ superior, entretanto, consagra:

"La Constitución es norma de normas. En todo caso de incompatibilidad entre la Constitución y la ley u otra norma jurídica, se aplicarán las disposiciones constitucionales. Es deber de los nacionales y de los extranjeros en Colombia acatar la Constitución y las leyes, y respetar y obedecer a las autoridades".

De dicho precepto despunta un principio estructurante del orden jurídico colombiano: la supremacía de la Constitución Política sobre el resto de prescripciones del sistema de derecho positivo. En consecuencia, el conjunto de preceptos que integran el derecho positivo se ordena en un sistema normativo, en virtud de la unidad y coherencia que le imprimen los valores, principios y reglas establecidas en la Constitución. Esta noción de supremacía constitucional "parte de la naturaleza normativa de la Constitución, que se revela en el carácter de fuente primaria del ordenamiento jurídico" (C. Const., sentencia C-415/12).

A su turno, el artículo $6^{0}$ de la Carta Política señala la responsabilidad de los particulares y de los servidores públicos, conviniendo que éstos responden por sus omisiones o extralimitaciones en el ejercicio de sus funciones.

Lo anterior equivale a dar por sentado que, mientras los particulares pueden hacer todo aquello que no les esté expresamente prohibido por la Constitución y la ley, los funcionarios del Estado tan sólo pueden hacer lo que estrictamente les está permitido por ellas. Y es 
natural que así suceda, pues quien está detentando el poder necesita estar legitimado en sus actos, y esto opera por medio de la autorización legal (C. Const., sentencia C-337/93).

Desde luego, esta preceptiva es una pieza clave para la seguridad del orden social justo y para la claridad en los actos que realicen los que detentan el poder público en sus diversas ramas.

Por su parte, el artículo 13 superior, consagra el derecho a la igualdad de todas las personas ante la ley, del cual se desprenden a su vez la igualdad frente a las cargas públicas, y la igualdad de trato por parte de las autoridades públicas y de oportunidades. La igualdad comprendida dentro del catálogo de los derechos fundamentales de la Constitución Política es una relación que se da al menos entre dos personas, objetos o situaciones, y que involucra usualmente, cargas, bienes o derechos constitucionales o legales (C. Const., sentencia T-401/92).

El principio de igualdad supone la realización de un juicio de igualdad, a la vez que excluye determinados términos de comparación como irrelevantes; es así como en atención a dicho principio se prohíbe a las autoridades dispensar una protección o trato diferente y discriminatorio "por razones de sexo, raza, origen nacional o familiar, lengua, religión, opinión política o filosófica". De este modo, el artículo 13 de la Carta Política consta de seis elementos: 1) Un principio general; 2) la prohibición de discriminaciones; 3) el deber del Estado de promover condiciones para lograr la igualdad real y efectiva; 4) la posibilidad de conceder ventajas a grupos discriminados 0 marginados; 5) una especial protección a personas que por su condición económica, física o mental se encuentren en circunstancias de debilidad manifiesta; y 6) la sanción de abusos y maltratos que se cometan contra personas en circunstancias de debilidad (Cepeda, 1992: p. 52).

Sin embargo, el artículo 13 de la Carta Fundamental no prescribe siempre un trato igual para todos los destinatarios de las normas, puesto que toda desigualdad no constituye necesariamente una discriminación; la igualdad sólo se viola si la desigualdad está desprovista de una justificación objetiva y razonable, y la existencia de dicha 
justificación debe apreciarse según la finalidad y los efectos de la medida considerada, debiendo darse una relación razonable de proporcionalidad entre los medios empleados y la finalidad perseguida.

Así entonces, la diferencia de trato entre personas que se encuentran en igualdad de condiciones, no conduce ineludiblemente a un juicio de discriminación. De tal forma, el tratamiento diferenciado puede encontrar una justificación objetiva y razonable, que tienda a la búsqueda de fines constitucionales, o a la protección de bienes protegidos por el texto fundamental. Por el contrario, cuando el trato disímil no se encuentra justificado 0 atenta directamente contra valores o principios del ordenamiento constitucional, se compromete el derecho a la igualdad. Del simple tratamiento diferenciado no se infiere la existencia de un trato discriminatorio. En estos casos, debe demostrarse, al menos indiciariamente, que la actuación acusada compromete valores o principios constitucionalmente tutelados, o que no encuentra justificación razonable y objetiva (Cepeda, 1992: p. 53).

Pues bien, según ha expresado la Corte Constitucional (sentencia T-352/97), para que una medida que establece un trato diferenciado en virtud de uno de los criterios constitucionalmente 'sospechosos' supere el juicio de igualdad y la presunción de inconstitucionalidad que la cobija, se requiere que se verifiquen los siguientes requisitos: 1) que persiga un objetivo constitucionalmente imperioso; 2) que obren datos suficientes para afirmar que resulta idónea para garantizar la finalidad perseguida; 3) que es ingente para alcanzar tal propósito; 4) que el beneficio que se busca obtener es mayor que el daño que causa; y 5) que el trato diferenciado se ajusta al grado de la diferencia que existe entre las personas o grupos de personas involucrados. Si una medida no cumple alguna de estas condiciones, compromete el derecho a la igualdad.

Entretanto, el artículo 58 superior consagra la propiedad privada como derecho constitucional. En consecuencia, las disposiciones constitucionales regulan y desarrollan lo atinente a este derecho y a todos aquellos derechos adquiridos con 
arreglo a las leyes civiles, siempre entendiendo que el interés privado debe ceder ante el interés público o social. La Corte Constitucional (Cf. sentencia C-189/06) ha definido la propiedad privada "como el derecho real que se tiene por excelencia sobre una cosa corporal o incorporal, que faculta a su titular para usar, gozar, explotar y disponer de ella, siempre y cuando a través de su uso se realicen las funciones sociales y ecológicas que le son propias".

Asimismo, la Alta Corporación (Cf. sentencias C-189/06, C-1172/04, C-133/09) ha señalado las características del derecho de propiedad privada de la siguiente manera:

\begin{abstract}
Al derecho de propiedad se le atribuyen varias características, entre las cuales se pueden destacar las siguientes: (i) Es un derecho pleno porque le confiere a su titular un conjunto amplio de atribuciones que puede ejercer autónomamente dentro de los límites impuestos por el ordenamiento jurídico y los derechos ajenos; (ii) Es un derecho exclusivo en la medida en que, por regla general, el propietario puede oponerse a la intromisión de un tercero en su ejercicio; (iii) Es un derecho perpetuo en cuanto dura mientras persista el bien sobre el cual se incorpora el dominio, y además, no se extingue -en principio- por su falta de uso; (iv) Es un derecho autónomo al no depender su existencia de la continuidad de un derecho principal; ( $v$ ) Es un derecho irrevocable, en el sentido de reconocer que su extinción o transmisión depende por lo general de la propia voluntad de su propietario y no de la realización de una causa extraña o del solo querer de un tercero, y finalmente, (vi) Es un derecho real teniendo en cuenta que se trata de un poder jurídico que se otorga sobre una cosa, con el deber correlativo de ser respetado por todas las personas.
\end{abstract}

Ahora bien, de la fórmula del Estado social de Derecho se deriva que los ciudadanos gozan de una amplia gama de derechos fundamentales y de posibilidades de controlar el poder político. Sin embargo, los asociados no solamente cuentan con derechos, sino también con deberes. Ciertamente, se observa que en la Carta Política se contemplan tanto derechos y libertades fundamentales como deberes ineludibles de las personas y del ciudadano, imprescindibles para la convivencia social.

Justamente, uno de los principios básicos en que se inspira la Constitución Política de 1991 es el de 'reciprocidad' (art. 95 C. Pol.), el cual consiste en que así como la Constitución reconoce y brinda derechos y garantías a las personas, para éstas existe el cumplimiento de ciertos deberes (C. Const., sentencia T-532/92); dicho en otros términos, correlativamente a los derechos constitucionales aparecen los deberes del mismo orden, con idéntica fuerza vinculante (Gómez Pavajeau, 2011: p. 30). Además, el principio de reciprocidad "es garantía de las relaciones adecuadas entre el Estado y 
el individuo, al generar derechos y deberes para ambas partes, y de éstas para la comunidad" (Henao Hidrón, 1994: p. 175).

Igualmente, dentro del contexto del Estado social constitucionalizado, en la base de los deberes sociales se encuentra presente expresamente en el Texto Superior el "principio-deber de solidaridad" (arts. 1 y 95, num. 20 Const.. Pol.). El carácter normativo de la Carta Fundamental obliga a conferir un valor jurídico a la solidaridad y, en este ámbito, su configuración como auténtica obligación jurídica no plantea problemas. Por decirlo con mayor claridad, la solidaridad que es un hecho y un valor que precede a la Constitución se concreta y traduce en un deber jurídico a través de su inclusión por el Constituyente de 1991. La recepción constitucional del principio de solidaridad convierte el ser en deber ser, el hecho de la solidaridad en el deber de solidaridad (Tajadura Tejada, 2007: p. 70).

En cuanto tal, el principio de solidaridad en el Estado social, deja de ser un imperativo ético para convertirse en norma constitucional vinculante para todas las autoridades públicas y personas que integran la comunidad (art.1 Const. Pol. / Corte Const., sentencias T-406/92, T-533/92). Por ello, para superar sentimientos egoístas y egocéntricos que están dentro de sí, deben cumplirse a cabalidad los deberes impuestos por la Constitución y la Ley, y de manera excepcional, sin mediación legislativa, cuando su desconocimiento comporta la violación de un derecho fundamental (Corte Const., sentencias T-406/92, T-532/92, T- 533/92, T-015/95, T389/99, T-1634/00, T-520/03, T-419/04, T-312/10).

Así las cosas, en el modelo de Estado social acogido por Colombia, toda autoridad pública y persona tiene el deber constitucional de obrar de conformidad con el principio de solidaridad social. La primera consecuencia que se desprende de este principio guarda relación con la exigibilidad de los deberes u obligaciones impuestas por la Constitución o por Ley a determinadas autoridades o personas, bien por la vía de los mecanismos ordinarios, o mediante el ejercicio de la acción de tutela, cuando ello sea 
necesario para impedir eficazmente la vulneración o amenaza de un derecho constitucional fundamental (Corte Const., sentencia T-533/92).

En suma, de las normas constitucionales estudiadas, entre otras, se colige la responsabilidad del Estado Legislador en Colombia, puesto que de ellas se desprende la cláusula general de responsabilidad patrimonial del Estado, bien sea de orden extracontractual, precontractual, contractual, y su fundamento estriba en la noción de daño antijurídico, el cual descansa en los principios de solidaridad y de igualdad, y no en la idea de la actividad ilícita del Legislador, entendida como tal las actuaciones contrarias a la Constitución.

En efecto, la cláusula general de responsabilidad patrimonial del Estado consagra la obligación de reparar los daños antijurídicos provenientes de cualquier autoridad pública. Ciertamente -como se ha reiterado-, la cláusula general de responsabilidad simplemente establece dos requisitos para que opere la responsabilidad patrimonial estatal, a saber, que haya un daño antijurídico, y que éste sea imputable a una acción u omisión de una autoridad pública, sin hacer distingos en cuanto al causante del daño.

De ahí que el Estado deberá responder por los perjuicios ocasionados como consecuencia de un daño antijurídico, es decir, aquél que el administrado no está en el deber jurídico de soportar, lo que por sustracción de materia necesariamente excluye aquellos daños que jurídicamente deben soportar los administrados, pues éstos son cargas que se imponen indiscriminadamente a las personas y que deben aceptar por el hecho de convivir en sociedad, como es el caso del pago de impuestos, tasas y contribuciones; la limitación temporal de su derecho de libertad y de locomoción cuando se trata del servicio militar obligatorio, etc. Lo anterior no significa que la responsabilidad del Estado Legislador se vea circunscrita exclusivamente a los anteriores eventos (Corte Const., sentencia C-038/06). 
No está de más señalar que la Carta Fundamental señala expresamente determinados supuestos de obligación reparatoria por la actuación del Legislador, tales como la figura de la expropiación (art. 58), la obligación de indemnizar cuando se establece un monopolio (art. 336), o cuando el Estado decide reservarse determinadas actividades estratégicas o servicios públicos (art. 365).

\title{
5.2. TRATAMIENTO DE LA RESPONSABILIDAD DEL ESTADO LEGISLADOR POR LA JURISPRUDENCIA CONSTITUCIONAL COLOMBIANA
}

\begin{abstract}
La estructura normativa de los Estados constitucionales de Derecho se caracterizan por la pertinencia de las normas vigentes a diversos planos (constitucional, legal, reglamentario, etc.), jerárquicamente ordenados, cada uno de los cuales se configura como normativo respecto del inferior, y como fáctico en relación al superior. Lo cual evidencia el sometimiento absoluto de toda fuente de producción normativa al nivel superior de normas, especialmente a la Constitución (Serrano, 1999: p. 59).
\end{abstract}

En Colombia, de este modo, el artículo 4ํㅡㄹ de la Carta Política de 1991 consagra lo ya citado: "La Constitución es norma de normas. En todo caso de incompatibilidad entre la Constitución y la ley u otra norma jurídica, se aplicarán las disposiciones constitucionales. Es deber de los nacionales y de los extranjeros en Colombia acatar la Constitución y las leyes, y respetar y obedecer a las autoridades".

De dicho precepto constitucional, despunta un principio estructurante del orden jurídico colombiano: la supremacía de la Constitución Política sobre el resto de prescripciones del sistema de derecho positivo. De esta suerte, el conjunto de prescripciones que integran el derecho positivo, se ordena en un sistema normativo, en virtud de la unidad y coherencia que le imprimen los valores, principios y reglas establecidas en la Constitución.

Pues bien, en un Estado de Derecho en el cual sus fuentes formales se organizan bajo una estructura estratificada, y en la cual la validez de las normas inferiores depende de su conformidad y adecuación sustantiva y procedimental a las superiores, la actividad del legislador constituye un hecho respecto de las normas de la Constitución Política; esto quiere significar que las actuaciones del legislador son a la vez normativas y fácticas, esto es, crea normas, pero sujetas a otras normatividades de rango superior. 
Para tal efecto, el constituyente de 1991 le confió "la guarda de la integridad y supremacía de la Constitución" a la Corte Constitucional, en los estrictos y precisos términos señalados en el artículo 241 de la Carta Fundamental.

Para el desarrollo de esta misión -y como herramienta de control constitucional de la ley que permite constatar su contravención absoluta con el texto superior, declarando su inconstitucionalidad con efectos generales-, la Carta Fundamental de 1991 consagró expresamente la acción de inconstitucionalidad.

En efecto, en ejercicio de dicha acción constitucional, la Corte Constitucional debe "confrontar las disposiciones sometidas a su control con la totalidad de los preceptos de la Carta Política, haciendo de sus fallos tránsito a cosa juzgada de rango constitucional" (Henao Hidrón, 2006: p. 103). Como corolario lógico de ello, contra la sentencias de la Corte Constitucional, no procede recurso alguno.

Ahora bien, en principio, si bien las sentencias que profiera el Tribunal Constitucional tienen efectos hacia el futuro, también la misma corporación puede resolver lo contrario (art. 45, ley 270/96), esto es, modulando su sentencia otorgándole efectos 'ex-tunc' a la decisión. Ciertamente, al existir en Colombia -conforme con el artículo 241 de la Carta Fundamental- control de constitucionalidad en cabeza de la Corte Constitucional, es posible que, tal como se señaló en la sentencia C-149 de $1993^{8}$, el Alto Tribunal, al modular sus decisiones, otorgue efectos 'ex-tunc' a la sentencia y, como consecuencia de dicha retroactividad, se genere responsabilidad patrimonial del Estado por leyes inconstitucionales.

\footnotetext{
${ }^{8}$ Sin duda, el caso más conocido de una decisión modulada de la Corte Constitucional es el de la sentencia C-149 de 1993, en la cual se declaró la inconstitucionalidad de los artículos 16, 17 y 18 de la Ley 6ª de 1992, y se ordenó al Ministerio de Hacienda y Crédito Público reintegrar la totalidad de las sumas recaudadas por concepto de las disposiciones inexequibles.
} 
Evidentemente, la declaratoria de inconstitucionalidad de una norma jurídica determinada equivale a la declaración de nulidad absoluta de la ley, de tal manera que la sentencia estimatoria de inconstitucionalidad de la Corte Constitucional sería base suficiente para que aquellos administrados que estimen que han sufrido una lesión antijurídica, acudan a la jurisdicción contencioso-administrativa a obtener su resarcimiento.

\section{En este orden de ideas,}

si bien no corresponde a la Corte Constitucional la reparación de los daños antijurídicos causados por la actividad del Legislador, excepcionalmente, en algunas ocasiones, mediante la técnica de modular los efectos temporales a sus decisiones ha permitido el resarcimiento de algunos de los perjuicios patrimoniales causados por leyes inconstitucionales, de manera específica al darle eficacia retroactiva a sus sentencias (Corte Const., sentencia C-038/06).

Por consiguiente,

cuando el legislador está bajo el paradigma de la Constitución, esto es, sometido a un orden jurídico que no puede cambiar ni desobedecer $y$, sin embargo, se promulga una ley que desconoce preceptos constitucionales y con ella se irroga un perjuicio particular, concreto y económicamente estimable, no existen dudas de que éste constituirá un potencial daño jurídico inevitablemente indemnizable (Retis Amaya, 2005: p. 61).

La responsabilidad del Estado Legislador en este evento deviene por el carácter de Norma Suprema de la Carta Política y la consecuente subordinación del poder legislativo a sus prescripciones, de tal manera que la vulneración de la Constitución en el ejercicio de la potestad legislativa determina la posibilidad de que surja la responsabilidad del Estado legislador en los casos en que se ocasionen daños a los administrados.

Sin duda alguna, la expedición de una norma que luego es declarada inexequible cualquiera sea su rango-, constituye una falla en el servicio que genera un daño antijurídico, puesto que está expresamente consagrado en el artículo 90 de la Carta Fundamental: la obligación de reparar los daños antijurídicos provenientes de hechos, acciones $u$ omisiones imputables al Poder Legislativo, debido a que cualquier otra posibilidad sería abiertamente inconstitucional desde la perspectiva del Estado Social de Derecho, y de los principios y valores que rigen nuestro ordenamiento constitucional 
tales como la solidaridad, la igualdad, la justicia material y la supremacía de la Constitución.

"En efecto, como se ha reiterado, el precepto simplemente establece dos requisitos para que opere la responsabilidad patrimonial estatal, a saber, que haya un daño antijurídico y que éste sea imputable a una acción u omisión de una autoridad pública, sin hacer distingos en cuanto al causante del daño" (Corte Const., sentencia C-038/06).

No obstante, la Corte Constitucional ha advertido:

El control de constitucionalidad no es un requisito 'sine qua non' para el reconocimiento de la responsabilidad del Legislador, y como bien señala la doctrina, la conexión entre las teorías del control de constitucionalidad y de la responsabilidad del legislador es cuando menos problemática, pues no toda declaratoria de inconstitucionalidad implica responsabilidad estatal, ni todo reconocimiento de la responsabilidad del legislador tiene como requisito la previa declaratoria de inconstitucionalidad de una norma (Corte Const., sentencia C-038/06)

\subsection{TRATAMIENTO DE LA RESPONSABILIDAD DEL ESTADO LEGISLADOR POR LA JURISPRUDENCIA CONTENCIOSO-ADMINISTRATIVA COLOMBIANA, Y TÍTULOS DE IMPUTACIÓN}

La responsabilidad del Estado Legislador no solamente debe verse circunscrita exclusivamente a los eventos o a los supuestos de responsabilidad legislativa constitucionalmente establecidos, a saber: la expropiación (art. 58, Const. Pol), la obligación de indemnizar cuando se establece un monopolio (art. 336, Const. Pol.), o cuando el Estado decide reservarse determinadas actividades estratégicas o servicios públicos (art. 365, Const. Pol.). Asimismo, la responsabilidad del Estado Legislador no puede advertirse que provenga solamente cuando se produce la declaratoria de inconstitucionalidad de las leyes.

En efecto, la Corte Constitucional en sentencia C-038 de 2006 reconoce que los eventos de responsabilidad legislativa constitucionalmente establecidos no son los únicos, y le reconoce competencia al legislador y a la jurisprudencia de lo contenciosoadministrativo como fuentes determinadoras de otros supuestos y de los títulos de imputación en la materia, puesto que -como ya se ha dicho- el fundamento de la responsabilidad del Estado Legislador estriba en la noción de daño antijurídico, la cual 
gravita en los principios de solidaridad y de igualdad, y no en la idea de la actividad ilícita del Legislador, entendida como tal las actuaciones contrarias a la Constitución.

En consecuencia, la jurisprudencia contencioso-administrativa en varias sentencias del Consejo de Estado, le ha dado vida a la responsabilidad del Estado Legislador en Colombia, por eventos o supuestos diferentes a los anteriormente descritos.

De este modo, en el primer evento en el que el Máximo Tribunal de lo ContenciosoAdministrativo abordó el tema, fue la sentencia de Sala Plena del 25 de agosto de 1998, proferida dentro de la reparación directa de número IJ-001 -demandante Vitelvina Rojas Robles y otros-, demandada por el Ministerio de Relaciones Exteriores y el Congreso de la República - Representado por el Ministerio del Interior.

Pues bien, en este asunto la parte actora presentó demanda de reparación directa en contra de la Nación-Ministerio de Relaciones Exteriores y el Congreso de la República, con el fin de obtener la indemnización por los perjuicios que le fueron ocasionados y que derivaron de la aplicación de la Ley $6^{\underline{a}}$ de 1972, mediante la cual se aprobó la Convención de Viena sobre relaciones diplomáticas.

Tal demanda se fundamentó en que los actores no pudieron reclamar por la vía judicial ordinaria (civil ni penal), la indemnización de los perjuicios ocasionados por la muerte del señor Julio César Cuervo Pineda, quien falleció en accidente de tránsito a manos de un agente diplomático miembro de la delegación de Estados Unidos de Norteamérica, puesto que la norma en comento estableció inmunidad jurisdiccional a favor de los agentes diplomáticos, razón por la que el operador jurídico colombiano fundamentó carecer de competencia para conocer de ese asunto.

El Tribunal Contencioso-Administrativo emitió el 9 de febrero de 1995 sentencia de primera instancia, accediendo a las súplicas de la demanda, señalando que el acto de la expedición de la Ley 6 1972 no ocasionó perjuicios a los actores, así como no lesionó ninguno de sus derechos, ya que tal norma se circunscribe a ratificar la 
Convención de Viena que regula las relaciones diplomáticas entre los Estados que la suscribieron, estableciendo la inmunidad de jurisdicción para los miembros de las misiones diplomáticas acreditadas ante el respectivo Estado receptor, y no existe responsabilidad por el acto legislativo puesto que éste

no es violatorio de mandatos constitucionales que otorguen específicos derechos a las personas que se sienten lesionadas por su expedición, todo ello dentro de la organización jerárquica del sistema jurídico, o que la misma ley -dada la naturaleza de la materia regulada- ordena la indemnización de aquellos que, como resultado de su aplicación, vean disminuido su patrimonio en forma más gravosa que la que corresponde al común de quienes integran el conglomerado social sometido al imperio de la norma.

También argumentó el juez de primer grado, que en la ejecución del hecho dañoso no participó ningún agente del Estado Colombiano, ni se produjo como consecuencia del desarrollo de la función estatal en alguno de los campos propios de la misma; no obstante, y atendiendo el principio 'iura novit curia' y de justicia, el Estado tiene la obligación de resarcir los perjuicios ocasionados a los actores porque con la aplicación de la Convención de Viena sobre relaciones diplomáticas aprobadas por la ley $6^{\underline{a}}$ de 1972 -que concede inmunidad de jurisdicción-, colocó a los colombianos en la imposibilidad de obtener acceso a la administración justicia y se les menoscabó su derecho a ser iguales ante la ley, impidiéndose así que aquéllos a quienes se podía imputar el hecho respondieran de los perjuicios que se les ocasionaron.

El anterior fallo de primera instancia fue impugnado por los dos extremos de la litis o pleito. La parte actora señaló su disconformidad respecto a la tasación de los perjuicios materiales. Por su parte, las entidades públicas demandadas argumentaron su descontento, indicando que la inmunidad diplomática es referente a las relaciones interestatales, y desconocerlo afectaría de nulidad absoluta los pactos que desconozcan tal institución; asimismo, indican que el Estado Colombiano es ajeno a los hechos a las consecuencias de la inmunidad.

Agotadas las etapas de instancia, el Consejo de Estado reunido en Sala Plena, dictó sentencia por la que confirmó parcialmente la de primera instancia, puesto que modificó la condena de los perjuicios materiales, reduciendo el rubro concedido por el 'a quo'. 
De este modo, el Alto Tribunal se fijó como problema a dilucidar en la presente controversia: determinar si el Estado Colombiano debe reparar los daños antijurídicos ocasionados por un agente diplomático de comisión extranjera, a título de daño especial por el hecho legislador al aplicar la Ley 6ª de 1972.

Asimismo, precisó la Alta Corporación que la declaración de responsabilidad por el hecho del legislador, no requiere que exista siempre vulneración de los normas de carácter superior, ni de la licitud o ilicitud de la actividad, sino que tal responsabilidad emana de la antijuridicidad del daño. La orientación que el 'ad quem' le da al proceso, es que el demandando es el Estado Colombiano y el fundamento o daño antijurídico no es la muerte de la víctima, sino el desequilibrio de las cargas públicas ante la ley, puesto que la muerte sólo es un factor objetivo para determinar la indemnización.

Conforme al artículo 82 del C.C.A., es competente la jurisdicción contenciosoadministrativa para conocer de las consecuencias de la adopción de la Convención de Viena como ley, y de su aplicación en cumplimiento de compromisos internacionales, y los privilegios que el Estado Colombiano concede a Estados o a sus diplomáticos acreditados, y si éstos causan un daño, las consecuencias patrimoniales deben ser asumidas por la Nación Colombiana, conforme el artículo 90 de la Carta Magna. Así resulta establecido

El factor de imputación de la responsabilidad impetrada respecto del ente demandado por su titularidad jurídica exclusiva y excluyente para el manejo de las relaciones internacionales, que constitucionalmente implican una operación compleja con participación de las tres ramas del poder público, a saber, el ejecutivo encabezado por el Presidente de la República, a quien corresponde la dirección de las relaciones internacionales y, por ende, la negociación de los tratados; el legislativo, que incorpora los tratados internacionales como texto de derecho interno mediante leyes, y el judicial representado en el caso por la Corte Constitucional mediante el control automático que ejerce sobre dichas leyes.

Toda vez que los demandados -en virtud de la norma precitada- perdieron la oportunidad de demandar al autor material del daño y al propietario del vehículo automotor (Embajada de los Estados Unidos), se justifica la responsabilidad patrimonial del Estado Colombiano, en virtud de la garantía de acceder a la administración de justicia (art. 229 de la C.P). 
En cuanto al régimen de responsabilidad aplicable, es el de daño especial, por cuanto la incorporación de convenciones y tratados de carácter internacional es una actividad legítima y compleja del Estado, en cuya aplicación se produjo un daño consistente en el desequilibrio de las cargas públicas que los actores o una persona en particular no deben soportar. Por lo que resulta equitativo imponer al Estado, en representación de la sociedad, la obligación de reparar el perjuicio irrogado a los actores, en ejecución del principio de la igualdad ante la ley (artículo 13 de la C.P.).

Por otra parte, la jurisprudencia del Consejo de Estado ha consolidado los pronunciamientos con respecto al daño especial como fundamento de la responsabilidad patrimonial del Estado, señalando que éste se produce cuando en desarrollo de una actividad legítima de la administración se afectan los derechos ciertos y jurídicamente tutelados de una persona por el rompimiento de la igualdad frente a la ley y a las cargas públicas, el cual debe ser indemnizado por el Estado siempre que el mismo resulte anormal, excepcional y superior al que normalmente deben sufrir los ciudadanos (C.E., sentencias del 16 de julio de 1994, 19 de abril de 1994, 25 de septiembre de 1997).

En el caso concreto, entonces existe daño especial por cuanto los demandantes presentaron una doble limitación por la aplicación de la ley de inmunidad diplomática, de un lado porque quedan privados de la posibilidad de demandar en Colombia la reparación a que tienen derecho, en acción contra el ejecutor material del daño y, de otra parte, porque consecuencialmente se desequilibraron las cargas públicas que deben soportar todos los ciudadanos en igualdad de condiciones, al imponérseles la necesidad de demandar ante la justicia del estado acreditante.

Otro relevante evento en el desarrollo jurisprudencial de la responsabilidad del Estado Legislador en Colombia, fue la sentencia del 26 de marzo de 2014, proferida por la Sección Tercera del Consejo de Estado dentro de la reparación directa 25000-23-26000-2003-00175-01 (28.741), que tuvo como demandante a Goodyear de Colombia S. A., y como demandado a la Nación- Congreso de la República. 
Como fundamento fáctico de dicho proveído, se tuvo que el 10 de enero de 2003, la sociedad Goodyear de Colombia S. A. presentó demanda de reparación directa en la cual solicitó la declaración de responsabilidad patrimonial a la Nación- Congreso de la República, "por la expedición y aplicación de unas normas abiertamente inexequibles, como son los artículos 56 y 57 de la Ley 633 de 2000, que crearon la obligación de liquidar y pagar la Tasa Especial por Servicios Aduaneros [TESA]." Y como consecuencia de esa declaración, solicitó la devolución de $\$ 831$ '931.000 por las sumas pagadas de enero 31 a octubre 31 de 2001 a TESA.

La anterior demanda presentó como fundamento el hecho de que la parte actora debió cancelar a TESA unas tasas especiales equivalentes al $1.2 \%$ del valor FOB de los bienes objeto de importación, tributo impuesto en la Ley 633 de 2000; norma que posteriormente fue declarada inexequible por la Corte Constitucional a través de la sentencia C-992 del 19 de septiembre de 2001, por lo cual el gravamen era ilegítimo comoquiera que no tuvo fundamento constitucional ni cumplió tales requisitos, existiendo por ello una falla en el servicio legislativo. La Entidad demandada, en el ejercicio de su derecho de defensa, se opuso a las pretensiones de la demanda, aduciendo que el único evento en el que puede resultar condenada por su actividad legislativa, es cuando se presenta un desequilibrio de las cargas públicas constitutivas de un daño especial.

Luego de cumplidos los ritos procesales, el Tribunal Contencioso-Administrativo de Cundinamarca, el 27 de julio de 2004 profirió sentencia de primera instancia, acogiendo las súplicas de la demanda, fundamentando que ante la declaración de inconstitucionalidad de los artículos 56 y 57 de la Ley 633 de 2000 por la Corte Constitucional, se estaba en presencia de una falla en la función legislativa por la expedición de tales normas, por cuanto no estableció la forma en que se vinculaba la tasa creada a la utilización del servicio aduanero, pues se relacionó únicamente al valor del bien importado, perdiéndose de esta manera la diferencia existente entre la tasa y 
el impuesto, al hacer que dicha tasa se asimilara a un impuesto sobre las importaciones, razón por la cual su destinación especial era contraria a la Constitución.

Contra el fallo dictado en primera instancia, la entidad pública demandada presentó recurso de alzada, aduciendo -entre otros argumentos-, que la sentencia de inconstitucionalidad no determinó efectos retroactivos de la misma, por lo cual el recaudo realizado por la DIAN con anterioridad a la ejecutoria de la sentencia C-992 de 2001 fue legítimo, toda vez que durante ese período la ley era constitucional; el conocimiento y trámite del recurso de apelación le correspondió al Consejo de Estado, Corporación que agotó los trámites procesales de segunda instancia y dictó sentencia, confirmando el proveído dictado por el 'a quo'.

El problema por dilucidar en la presente controversia se concretó en determinar si ante la declaración de inexequibilidad de una norma, se genera responsabilidad patrimonial extracontractual del Legislador y, por ende, acarrea una reparación integral de la lesión o daño antijurídico ocasionado.

El Máximo Tribunal de lo contencioso-administrativo realizó un estudio concienzudo de las diferentes y opuestas posiciones que han tratado el tema de responsabilidad patrimonial por el hecho del legislador, la doctrina, el derecho comparado, especialmente con España y la evolución de la jurisprudencia contenciosoadministrativa, aludiendo que se deben reparar los daños no sólo por la ley expedida por el Congreso, sino a todas las normas caracterizadas por ser generales, impersonales y abstractas (actos administrativos, decretos-ley, resoluciones, etc.), expedidas por la función reguladora del Estado, de la que puede derivase el daño antijurídico, sin importar su grado.

A su vez, señaló que las objeciones a la declaratoria de responsabilidad del Estado por el hecho legislador carecen de fundamento en Colombia, comoquiera que en el artículo 90 de la Constitución Política no está consagrada ninguna excepción de responsabilidad patrimonial derivada de causar algún daño antijurídico por parte de 
algún órgano del Estado en ejercicio de su actividad, por lo que el órgano Legislativo no está exceptuado de estos juicios de responsabilidad, con lo cual resulta que el Juez Administrativo sí es el competente para conocer este caso específico.

Si bien es cierto que en esta clase de asuntos se está frente a un choque entre dos principios del derecho, esto es, la seguridad jurídica por una parte, y por otra la supremacía de la Constitución, surge la conclusión de que prevalece la supremacía de la Constitución para declarar la responsabilidad del legislador por la expedición de normas contrarias a ella, comoquiera que ella prevalece sobre las demás normas del ordenamiento jurídico, así como todos los poderes públicos tienen el deber y la obligación de acatarla y someterse a ella, regla que no contempla excepciones ni si quiera sobre el órgano legislativo.

A modo de ejemplo, citó las sentencias de 29 de febrero, 13 de junio y 15 de julio de 2000, mediante las cuales el Tribunal Constitucional Español declaró inconstitucionales varias leyes que establecían una serie de tributos, y condenó al Estado a indemnizar los perjuicios ocasionados a los sujetos pasivos del gravamen, por la aplicación de las normas declaradas inconstitucionales, puesto que el Poder Legislativo no está exento de sometimiento a la Constitución y sus actos están sometidos al imperio de ella; y, si la Ley vulnera la Norma Superior, se hace evidente que el Poder Legislativo transgredió su obligación de sometimiento, y la antijuridicidad que ello supone traerá consigo la obligación de indemnizar. Por tanto, la responsabilidad del Estado legislador puede tener, asimismo, su segundo origen en la inconstitucionalidad de la Ley.

Ahora bien, en la justicia contencioso-administrativa se han distinguido dos títulos de imputación en aquellos eventos en los que se ha declarado la responsabilidad del Estado en esta materia, a saber: i) daño especial, cuando el Estado debe responder por los daños causados en el ejercicio de su competencia reguladora, bien sea cuando estos se deriven de la expedición de una norma ajustada al ordenamiento superior, siempre y cuando quien lo padece no tenía en principio por qué sufrirlos; y ii) falla en el servicio, cuando se origine en una disposición que es declarada nula o inexequible, 
según el caso. Siendo este último - tal como sucedió en España-, el que ha encontrado mayores problemas en su aplicación.

El factor de imputación y el llamado a responder patrimonialmente en el caso de las leyes declaradas inexequibles, es el legislador, pese a no haber ejecutado la norma, justamente por haber creado y expedido el precepto inconstitucional. En virtud de lo cual y en el aspecto tributario, no es llamado a responder el que recaudó el tributo sino el que creó la ley contraria a la Constitución, comoquiera que el recaudador sólo es un agente del Estado que obra de buena fe y se encarga de hacer cumplir la ley y, de imputársele a éste el daño derivado de la falla, se trataría de restitución mas no de reparación.

Para el efecto se cita la sentencia C-038 de 2006 de la Corte Constitucional, por la cual se pronunció sobre la exequibilidad del artículo 86 del decreto 01 de 1984:

\begin{abstract}
En el que manifestó que la responsabilidad patrimonial del Estado derivada de los hechos del legislador, se encuentra expresamente contemplada en el artículo 90 de la Constitución, señalando que pueden existir varios supuestos en los que la actuación del legislador da lugar a la reparación, tales como la figura de la expropiación (artículo 58 C.N.), la obligación de indemnizar cuando se establece un monopolio (artículo 336 C.N.), o cuando el Estado decide reservarse determinadas actividades estratégicas o servicios públicos (artículo 335 C.N.); la responsabilidad del legislador no se limita sólo a esos eventos, pues puede existir imputación por daños por otros eventos derivados de la misma actividad reguladora del Estado, con fundamento en el daño antijurídico y en los principios de igualdad y solidaridad.
\end{abstract}

En cuanto a la antijuridicidad del daño, ésta proviene del hecho de que el legislador -al expedir una norma que es declarada inexequible-, se hace notoria la falta de sometimiento a la Constitución, lo cual constituye el juicio de reproche sobre el cual se estructura la 'imputatio iuris' del daño. De lo cual deviene que nadie está obligado a soportar las consecuencias adversas de una norma que nació a la vida jurídica, contrariando la Constitución bien sea por razones de forma o de fondo, pues de lo contrario se desvanecería el principio de la supremacía constitucional, fundamento del ordenamiento jurídico colombiano.

En lo que respecta a lo señalado por el recurrente en cuanto a que la Corte Constitucional, no señaló que la sentencia C-992 del 19 de septiembre de 2001 tuviese 
un efecto 'ex tunc' (hacia el pasado), por lo cual no hay lugar a reparar el daño ocasionado; la Sala precisó que si bien la declaración de dicho efecto debe ser expresa atendiendo los principios de justicia y seguridad jurídica; ello no obsta para que pueda accederse a la reparación del perjuicio, puesto que la intangibilidad de la situaciones jurídicas consolidadas antes de la declaratoria de inconstitucionalidad difiere del deber que tiene el legislador de resarcir el daño que ha causado con su actuación. El efecto hacia el futuro de las sentencias de inexequibilidad no tiene el propósito de impedir el acceso a la reparación del daño o negar la existencia de responsabilidad del legislador -y menos la antijuridicidad de aquél-, sino que pretende imprimirle estabilidad y seguridad a las relaciones que ya se consolidaron con fundamento en la disposición que fue expulsada del ordenamiento jurídico, las cuales permanecerán incólumes, pero quedando siempre la posibilidad de que quien se vio afectado con la norma pueda acudir al juez administrativo para que éste ordene al creador de la misma resarcir los perjuicios.

El Consejo de Estado concluye que los daños provenientes del hecho de la ley, ya sea por omisión, por la ley exequible o constitucional, o por la ley declarada inexequible, con independencia de los efectos del fallo del tribunal constitucional, son de naturaleza antijurídica y, consecuencialmente, reparables de manera integral de acuerdo con el artículo 16 de la ley 446 de 1998, según lo siguiente:

i) No son equiparables los efectos de la sentencia de inexequibilidad con los elementos de la responsabilidad. El fallo de la Corte Constitucional no determina la existencia o no del daño antijurídico, sino el conocimiento del mismo, aunado a la acreditación de una falla del servicio, esto es, que al ser retirada del ordenamiento jurídico la norma, la persona conoce de la antijuricidad y de la falla del servicio legislativo, siendo procedente desde ese momento demandar la responsabilidad patrimonial extracontractual del Estado por la vía de la reparación directa, para que sea reparado de manera integral el daño cualificado (antijurídico) irrogado. 
Ahora bien, para que el daño antijurídico sea indemnizable, debe ser estructurado, es decir necesario que concurran los siguientes aspectos con la lesión, cuya reparación se reclama:

- debe ser antijurídico, esto es, que la persona no tenga el deber jurídico de soportar la lesión;

- que se lesione un derecho, bien o interés protegido legalmente por el ordenamiento;

- que sea cierto, es decir, que se pueda apreciar material y jurídicamente.

El daño antijurídico o 'daño injusto' es el principal elemento sobre el cual se estructura la responsabilidad patrimonial de la administración pública, a la luz del artículo 90 de la Carta Política, entidad jurídica que requiere para su configuración de dos ingredientes:

- uno, material o sustancial, que representa el núcleo interior y que consiste en el hecho o fenómeno físico o material (v. gr.: la desaparición de una persona, la muerte, la lesión, etc.);

- y otro, formal que proviene de la norma jurídica, en nuestro caso de la disposición constitucional mencionada.

ii) La constitucionalidad o inconstitucionalidad -es decir, los efectos, la vigencia o la validez de las normas- no son elementos estructurales de la noción de daño antijurídico. Lo que determina la antijuridicidad del daño es:

- que esa alteración o afectación negativa a un estado de cosas favorable sea injusta, esto es, que lesione un interés jurídicamente tutelado, lícito y legítimo, y 
- que el ordenamiento jurídico en su conjunto -principios, valores y reglas según la clasificación de Robert Alexy- no le impongan a la persona el deber jurídico de soportarlo.

De manera que, si la sentencia de inexequibilidad fija criterios de suma importancia en la materia, tales como:

- el término de caducidad del medio de control de reparación directa;

- la delimitación de la falla del servicio,

- y la imputabilidad del daño en cabeza del Congreso de la República, esto no significa que la antijuridicidad del daño se derive de la misma, porque la intolerabilidad de la lesión se origina desde el mismo momento en que la ley fue promulgada con vicios de validez y, por lo tanto, con su aplicación afectó o transgredió los intereses legítimos de los particulares.

Por consiguiente, la validez y vigencia de la ley en el tiempo no tiene incidencia y repercusiones en el derecho de daños, porque con independencia a los efectos de la nulidad o inconstitucionalidad, el daño existe, es cierto, personal y, por obvias razones, la persona no se encuentra obligada a soportarlo. Y será daño antijurídico o injusto todo aquel que lesione un interés legítimo (v. gr.: el patrimonio) y que, a la luz del artículo 90 de la Carta Política, no tenga justificación o fundamento jurídico para su irrogación.

La afectación de la validez de las normas atiende a dos circunstancias que no se relacionan o interfieren con la responsabilidad patrimonial extracontractual del Estado:

- el resurgimiento de la vigencia de las normas derogadas por el ordenamiento inexequible o ilegal, 
- y la protección de situaciones jurídicas consolidadas a favor de personas que han obrado de buena fe, bajo el amparo de los principios de confianza legítima y seguridad jurídica.

Ahora bien, el papel del juez contencioso-administrativo -en este caso-, se limita a verificar si la conducta del creador de la norma reúne los presupuestos de responsabilidad del artículo 90, es decir, constatar la existencia del daño antijurídico, mas no a ejercer un control sobre la constitucionalidad del precepto, por lo cual no incursiona en la órbita de las competencias de la rama legislativa, pues no está creando ni modificando una ley, sino que su función es la de adoptar las medidas tendientes a la reparación integral o corrección de la situación que el particular no estaba en la obligación de soportar.

Finalmente, y en el asunto concreto, se señaló que la declaración de inexequibilidad de las normas se debió a que el demandado creó una tasa que no equivalía a ningún beneficio, por lo cual se trataba de un impuesto, y al ser declarada inconstitucional las normas, el Congreso incurrió en una falla en el servicio causando un daño antijurídico a la sociedad Goodyear S.A., que demostró haber pagado a TESA el gravamen aun cuando éste era contrario a la Constitución, con lo que está demostrado la existencia del daño antijurídico imputable al demandado, por lo que el Consejo de Estado confirmó la sentencia de primera instancia, y ordenó actualizar la respectiva condena a título de perjuicios materiales por la suma de mil cuatrocientos cuarenta y tres millones ochocientos ochenta y cuatro mil quinientos setenta y cinco pesos con veintidós centavos (\$1'443.884.575, 22).

El Consejo de Estado, en un nuevo pronunciamiento dictado dentro de la reparación directa \#25000-23-26-000-2003-01185-01(26702) -demandante Promigas Sociedad Anónima, demandado Nación-Congreso de la República-, efectuó un estudio de la responsabilidad patrimonial extracontractual del Estado, como consecuencia de la ejecución y aplicación de la norma declarada inconstitucional en los artículos 56 y 57 de la Ley 633 de 2000. 
Los hechos, pretensiones y fundamento legal de esta demanda son similares a los invocados dentro del proceso de reparación directa incoada por la sociedad Goodyear de Colombia S. A. -de la que se hizo el anterior análisis-, variando únicamente el 'quantum' de la pretensión por perjuicio material ocasionado.

En este proceso el Juez de primera instancia, es decir, el Tribunal ContenciosoAdministrativo de Cundinamarca, profirió sentencia mediante la cual negó las súplicas de la demanda por falta de material probatorio, comoquiera que no se demostró el daño (pago de la tasa), así como tampoco se aportó el prenombrado fallo de constitucionalidad. Inconforme con el fallo, el extremo activo presentó recurso de alzada, según cual el daño ocasionado es antijurídico -entre otros argumentos-, porque el cobro de la tasa rompió el equilibrio de las cargas públicas.

A diferencia de lo determinado por el 'a quo', el Consejo de Estado -en el fallo emitidoconcluyó que sí existe material probatorio con el que se acredite el pronunciamiento de la Corte Constitucional y el pago de la tasa creada por la Ley 633 de 2000, de acuerdo con las declaraciones recaudadas en el trámite de la primera instancia.

Como antecedente jurisprudencial, en cuanto a la responsabilidad del Estado por el hecho del legislador, citó la sentencia dictada, por la misma Corporación el 24 de octubre de 2013 (en el expediente No. 26690), bajo la ponencia del Dr. Jaime Orlando Santofimio Gamboa, en la cual se enuncian las diferentes posturas que ha adoptado la jurisprudencia frente a la responsabilidad del legislador, y en la que se decidió negar las súplicas de la demanda, puesto que se señaló que, al no estar modulados los efectos de la sentencia por la misma Corte Constitucional, no puede otro operador jurídico determinar tales efectos; por lo cual al ocurrir un hecho (el pago de la tasa) en la vigencia de la norma amparada en ese momento de la presunción de legalidad (arts. 56 y 57 de la Ley 633 de2000), resultó que se cumplió lo establecido en el ordenamiento jurídico; por lo tanto, no existió daño antijurídico a título de falla en el servicio o rompimiento de las cargas públicas. 
Pese a la acostumbrada postura, la Sala se apartó de ese pronunciamiento, teniendo como referente la providencia del Consejo de Estado, calendada el 23 de febrero de 2012 -dictada en el expediente No. 24665-, por la que se estableció la responsabilidad extracontractual del Estado, toda vez que la Administración ejecutó y cobró obligaciones tributarias contenidas en normas generales excluidas del ordenamiento jurídico; en ella se precisó que en el artículo 90 de la Constitución Política, no se excluye a ninguna autoridad de la responsabilidad de reparar los daños antijurídicos que causen, aun cuando ejerzan potestades normativas; igualmente hace referencia a que, pese a no discutirse los efectos de la sentencia de inconstitucionalidad, tales efectos no modifican las denominadas "situaciones jurídicas consolidadas" antes de la expedición de la correspondiente sentencia de nulidad. Lo cual no es circunstancia válida para impedir que el juez contencioso-administrativo ordene resarcir cuando la autoridad adoptó una decisión viciada de nulidad, puesto que dentro de su órbita no está la de realizar controles de "juridicidad" de la norma, ni determinar o modular los efectos de los fallos dictados en procesos de control de legalidad y constitucional de una norma, sino que su competencia se refiere a ordenar la reparación de los perjuicios ocasionados durante la vigencia de la norma eliminada del ordenamiento jurídico, siempre y cuando se reúnan los presupuestos del artículo 90 de la Constitución Política, puesto que tal actuación generó una situación jurídica consolidada.

En dicho precedente jurisprudencial, además fundamentan que el pago de un tributo creado por una norma que es posteriormente excluida del sistema jurídico vigente, constituye un verdadero daño antijurídico, comoquiera que el deber de pago carece de fundamento jurídico, puesto que fue creado por "una autoridad pública a través del ejercicio contrario a Derecho de su potestad normativa"; la reparación de los perjuicios ocasionados con la aplicación de las normas generales (legales y/o reglamentarias) que crean obligaciones de índole tributario y que posteriormente fueron declaradas inconstitucionales, tienen respaldo en los principios constitucionales y legales, de igualdad, buena fe, tutela de la confianza legítima y seguridad jurídica, puesto que los contribuyentes que pagaron cumplidamente la obligación impuesta sufrieron un 
detrimento patrimonial si se confronta su situación con la de aquellas personas que nunca pagaron el impuesto eliminado del sistema jurídico.

Así las cosas, y teniendo presente que procede la reparación de los daños y/o perjuicios ocasionados por el hecho del legislador conforme a la jurisprudencia aplicable enunciada anteriormente, el Consejo de Estado -en el 'sub lite'-, realizó una valoración de cada uno de los elementos que determinan la procedencia de declarar la responsabilidad extracontractual del Estado, concluyendo que el demandante -al haber pagado la Tasa Especial de Servicios Aduaneros que impuso la norma declarada inconstitucional-, generó un daño antijurídico creado por la autoridad pública demandada; por lo cual se decisión fue la de revocar la sentencia de primera instancia, y en su lugar, declaró la responsabilidad patrimonial extracontractual del Estado -y como consecuencia y a título de condena-, ordenó reparar el daño ocasionado, disponiendo la devolución actualizada de las sumas pagadas por el tributo irregularmente creado.

Otro pronunciamiento proferido por el Consejo de Estado, lo realizó a través de la sentencia de 27 de marzo de 2014, proferida dentro de la reparación directa \#2500023-26-000-2002-02117-01(29146) -demandante Elsy Esterlina Martínez Arteaga, demandado Nación-Congreso de la República-.

En el proceso en cita, la señora Elsy Esterlina Martínez Arteaga presentó demanda de reparación directa, en la cual solicitó la declaración de responsabilidad patrimonial de la Nación-Congreso de la República,

por la omisión en el cumplimiento de los fallos de reintegro y pago de salarios y tutela, proferidos por el Tribunal Administrativo de Cundinamarca-Sección Segunda y Consejo de Estado, respectivamente, y por las consecuencias nocivas de la resolución 1533 de 29 de agosto de 2002, mediante la cual el Presidente de esta última Corporación se abstuvo con clara violación de la ley de darle cumplimiento a esos fallos,

y, como consecuencia de esa declaración, solicitó el reconocimiento y pago de todos los perjuicios que le fueron ocasionados. 
El fundamento fáctico que soportó la demanda de reparación directa fue el hecho de que la aquí demandante resultó ser parte vencedora en el proceso de nulidad y restablecimiento del derecho -en contra de la misma entidad que demandó en el 'sub júdice', fallo en el que se ordenó a la demandada el reintegro de la señora Martínez Arteaga al cargo que desempeñaba, así como el pago de salarios y prestaciones laborales dejados de percibir; no obstante, y pese a la orden judicial impartida por el Juez Contencioso Administrativo así como por el Juez de Tutela, la demandada solamente emitió acto administrativo Resolución 1533 de 29 de agosto de 2002, mediante el cual daba cumplimiento parcial a la orden judicial enunciada. Con lo que se le causó una serie de daños materiales y morales, lo cual a juicio de la demandante constituye una falla en el servicio y una 'vía de hecho' por el rompimiento del principio de igualdad frente a las cargas públicas.

La Entidad demandada, en el momento procesal oportuno, propuso como excepción el ejercicio de acción indebida, comoquiera que al tratarse de un acto administrativo, la acción procedente era de nulidad y restablecimiento del derecho, y no la invocada por la demandante.

Agotadas las etapas propias del proceso, el Tribunal Contencioso-Administrativo de Cundinamarca, el 21 de septiembre de 2004 profirió sentencia de primera instancia, por medio de la cual declaró no probada la excepción propuesta con el argumento de que la reparación directa sí es la acción procedente por cuanto con ella se pretende la indemnización de los perjuicios ocasionados con el acto administrativo expedido por la demandada; pese a lo anterior, denegó las súplicas de la demanda, puesto que el fallo administrativo laboral fue cumplido, por cuanto se ordenó el pago de los salarios y prestaciones laborales dejados de percibir por la actora desde la aceptación de la renuncia y hasta la fecha de terminación de aquél, el cual debe entenderse que es por el período legislativo por el cual fue designado el Representante de la Cámara de Representantes, según consta en la resolución No. 0028 de 23 de enero de 1997 y, ante la evocación de temporalidad del cargo, hace imposible su restitución al mismo. 
En desacuerdo con la anterior decisión, la parte actora presentó recurso de apelación en contra de la sentencia de primera instancia, en la cual insistió en que deberían prosperar las pretensiones invocadas, por cuanto existió mora en el cumplimiento de los fallos de nulidad y restablecimiento del derecho, reiterando que además dicho cumplimiento fue parcial, con lo que se provocó el rompimiento del principio de igualdad frente a las cargas públicas.

En el trámite de segunda instancia, y en el respectivo fallo proferido por el 'ad quem', se hizo en un primer plano un análisis normativo y jurisprudencial de la protección de la trabajadora pública en estado de gravidez -y en especial la estabilidad laboral reforzada de la que es beneficiaria-, igualmente señaló que toda las autoridades y la administración debían sujetarse a las órdenes judiciales. Luego, señaló que, si bien es cierto la entidad demandada a través de actos administrativos expedidos ulteriormente, esto es, resoluciones 1301 y 1302 de 2007, reconoció a la actora varios de los emolumentos pretendidos por salarios, prestaciones sociales y daños, no es menos cierto que no existió reparación integral, puesto que no hubo compensación por los daños morales sufridos por aquella, máxime que existió discriminación de la mujer embarazada, pese a existir disposiciones tanto constitucionales como internacionales que otorgan la garantía reforzada de estabilidad laboral; además, porque hubo un lapso considerable de seis (6) años en que no existió actividad por parte del extremo pasivo, ni la demandante obtuvo compensación alguna, debiendo por ello acudir a diferentes vías judiciales para lograr el pago pretendido. Sin más preámbulos argumentó que con ello se le impusieron cargas adicionales que no debía soportar la demandante, vulnerando "gravemente las garantías de estabilidad laboral reforzada de la mujer embarazada y acceso efectivo a la administración de justicia, en la medida que se dilató injustificadamente el cumplimiento de una decisión judicial", siendo por ello procedente decretar de oficio medidas de justicia restaurativa (de rehabilitación, satisfacción o garantías de no repetición).

Por lo anterior, revocó la sentencia de primera instancia, y condenó a la Nación-Senado de la República-Cámara de Representantes, a pagar a la actora los perjuicios morales 
ocasionados, y como medidas de satisfacción, impuso al Presidente de la Cámara de Representantes, ofrecer excusas a la demandante por la dilación injustificada en el cumplimiento del fallo; y como medidas de no repetición ordenó:

Adoptará las medidas administrativas y legislativas necesarias para que: (i) las mujeres vinculadas de las Unidades de Trabajo Legislativo no sean despedidas en estado de embarazo y durante el periodo de lactancia, y (ii) en los eventos en que se comentan infracciones al fuero de maternidad y se ordene judicialmente el reintegro, la medida de reubicación en el servicio se cumpla de forma oportuna y real.

Finalmente, me permito citar, otra sentencia de la misma Corporación ContenciosoAdministrativa, calendada el 26 de marzo de 2014 proferido dentro del proceso número 44001-23-31-000-2001-00282-01(28864) -demandante: Luis Alberto Cobo Corzo, contra la Nación-Ministerio del Interior-Ministerio de Justicia y del Derecho-Congreso de la República-.

En el proceso anteriormente referido, el actor solicitó la declaración de responsabilidad patrimonial de las entidades públicas demandadas,

por la expedición del aparte final del parágrafo segundo del artículo 39 de la ley 443 de 1998, posteriormente declarado inexequible, y la aplicación de sus efectos en la situación particular del actor, en cuanto lo privó del ejercicio de su derecho fundamental de acceso a la administración de justicia, y consecuencialmente, de la posibilidad de debatir judicialmente su derecho al trabajo, a través de la acción de nulidad y restablecimiento del derecho.

Y, como consecuencia, de tal declaración solicitó se condenara a las demandadas al pago de los perjuicios materiales y morales sufridos por él.

El demandante sostuvo que el artículo 39 de ley 443 de 1998 reguló los derechos de los empleados de carrera administrativa en casos de supresión de cargos, y señaló que el término de caducidad de la acción de nulidad y restablecimiento del derecho se contaría a partir de la declaratoria de nulidad del acto administrativo que suprimió el cargo. Luego, mediante la expedición del Decreto 2479 de 2000 -por el cual se facultó al Director del INAT reorganizar la planta global del Instituto Nacional de Adecuación de Tierras-, de acuerdo con esto, el Director del INAT expidió las resoluciones Nos. 0037, 00060 y No.00588 del 31 de enero de 2000, por cuyo medio se informó al actor que el cargo que venía desempeñando fue suprimido. 
Ulteriormente, y a través de la sentencia C-1341 de 2000, la Corte Constitucional declaró la inexequibilidad del parágrafo segundo del artículo 39 de la Ley 443 de 1998, referente a que "los términos de caducidad establecidos en el código contenciosoadministrativo para instaurar la acción de nulidad y restablecimiento del derecho se contarán a partir de la declaratoria del acto administrativo que originó la supresión del empleo". Dicha declaratoria impidió que el demandante presentara la demanda de nulidad y restablecimiento del derecho contra la Resolución No. 0037 de 2000, puesto que la acción le caducó.

Dentro del traslado de la demanda, el Ministerio de Justicia y del Derecho excepcionó falta de legitimación en la causa por pasiva, puesto que el llamado a ser parte es la Dirección Ejecutiva de Administración Judicial. Por su lado, el Congreso de la República señaló que la acción de reparación directa no es la idónea para cuestionar los posibles daños cuyo origen sea por el cumplimiento de la función del Congreso.

El Tribunal Administrativo de la Guajira expidió sentencia de primera instancia, declarando probada la excepción propuesta por el Ministerio de Justicia y del Derecho, y negó la prosperidad de las demás excepciones así como de las pretensiones de la demanda, toda vez que no ha sido consagrada ni por la Constitución ni por la ley la responsabilidad por el hecho de la ley; además de no existir daño ocasionado con la declaratoria de inexequibilidad de la ley en comento, puesto que el demandante podía acudir a la justicia Contencioso-Administrativa en demanda de nulidad; y, si bien pretendía el restablecimiento del derecho, el término de los cuatro (4) meses para incoar esta acción los podía contabilizar a partir de la ejecutoria del fallo por el cual se declaró la inexequibilidad de la segunda frase del parágrafo $2^{\circ}$ del artículo 39 de la Ley 443 de 1998.

Por su parte, el demandante presentó recurso de alzada en contra del fallo, señalando lo que a su juicio son los yerros cometidos por el 'a quo'; además, indicó que con la 
disposición en que fue declarada inexequible, se creó una situación jurídica de acceso restringido a la justicia, lo cual generó un daño cierto que debe ser reparado.

Para resolver el caso, el 'ad quem' realizó un recuento de la evolución jurisprudencial de la responsabilidad del Estado-Legislador por el hecho de causar un daño al expedir leyes, en el que se determinó que dicha declaración se puede presentar a título de riesgo excepcional o por violación del principio de igualdad frente a las cargas públicas, siempre y cuando el mismo legislador lo defina; posteriormente, se indicó que como los efectos de un fallo de inconstitucionalidad son hacia el futuro, por lo tanto los daños irrogados en la vigencia de la norma retirada del ordenamiento jurídico no pueden ser calificados como antijurídicos. Continuando con la evolución de la jurisprudencia, se indicó que la acción de reparación directa era procedente para la reparación de daños ocasionados por la aplicación de una norma inexequible, y aun cuando esto no obliga el reconocimiento de lo pretendido, sí se debe acreditar su existencia y su cuantía. Expone las sentencias que han declarado la responsabilidad patrimonial extracontractual del Estado, cuyo deber de indemnizar surge sin excepción alguna dando aplicación al artículo 90 de la Constitución Política. Igualmente reseñó las sentencias de la Corte Constitucional mediante las cuales se ha pronunciado sobre la responsabilidad del hecho del legislador, y en las que se extrae que éste no se puede limitar a las hipótesis previstas en la Constitución.

Bajo la apreciación de la jurisprudencia, la Sala que estudió el asunto concluyó que -de acuerdo con el artículo 90 de la Norma Superior-, puede surgir la responsabilidad del Estado, cuando en ejercicio de sus funciones legislativas causa un daño antijurídico a los particulares, cuyo título de imputación puede residir en cualquiera de los regímenes de responsabilidad (objetivo o subjetivo); bien sea por falla en el servicio o violación del principio de igualdad frente a las cargas públicas, su exigencia depende de los hechos alegados y probados en el proceso.

La Sala hizo explícita referencia a que las decisiones constitucionales son hacia el futuro en principio, y en los eventos en que el daño se causa por el retiro de la norma y 
éste sea antijurídico, existe una responsabilidad del Estado, pero para tal declaración debe estar modulado el efecto en la sentencia constitucional, puesto que al juez administrativo no le es dable abrogarse la facultad del Juez Constitucional de regular los efectos de los fallos constitucionales, ni desconocer la regla general; cuando estos no se indican de manera expresa, los mismos aplican hacia el futuro por expresa previsión del artículo 45 de la Ley 270 de 1996. Sin embargo, al hacer estudio del artículo 90 de la Carta Política, resulta claro que puede existir responsabilidad del Estado derivada de la norma declarada inexequible por la Corte Constitucional, siempre que se configuren los presupuestos constitutivos de responsabilidad, es decir, la existencia del daño antijurídico y la imputación al demandado.

En el estudio de los elementos de responsabilidad, la Sala determinó que no se encontró acreditada la existencia del daño antijurídico causado al actor, comoquiera que el demandante no demostró que al declararse inexequible el inciso final del parágrafo segundo de la Ley 443 de 1998, se le haya lesionado su derecho de acceso a la administración de justicia, puesto que tanto el artículo 85 y numeral $2^{\circ}$ del artículo 136 del Decreto 01 de 1984, consagraba el término de cuatro (4) meses para que el aquí demandante acudiera ante la justicia contencioso-administrativa en demanda de nulidad de los actos que suprimieron el cargo que aquél ocupaba y obtuviera el restablecimiento del derecho. De otra parte, se evidenció que la oportunidad para presentar dicha demanda administrativa había fenecido con anterioridad a la declaratoria de inexequibilidad del parágrafo segundo de la Ley 443 de 1998 dispuesto en la sentencia C-1341 de 2000. Con base en la inexistencia del daño antijurídico, se negó la declaratoria de responsabilidad estatal, confirmando así la sentencia de primera instancia. 


\subsection{MECANISMO DE CONTROL PARA RECLAMAR PERJUICIOS DERIVADOS DE LA ACTIVIDAD DEL LEGISLADOR Y TRÁMITE}

El Consejo de Estado, tanto en su Sala Plena de lo Contencioso-Administrativo (sentencias de 25 de agosto y 8 de septiembre de 1998) como en su Sección Tercera (sentencias de 26 de septiembre de 2002 y de 26 de marzo de 2014, y el auto de 15 de mayo de 2003), ha señalado de manera reiterativa, que la vía procesal adecuada e idónea para reclamar los eventuales perjuicios derivados de los daños antijurídicos provenientes de la actuación u omisión del poder legislativo, es el mecanismo de control de reparación directa.

Pues bien, Retis Amaya (2005: p. 51) ha definido la reparación directa como el medio procesal por medio del cual una persona natural o una persona jurídica, ya sea ésta de derecho público o de derecho privado, puede exigir ante la justicia contenciosoadministrativa, que el Estado la repare o indemnice por sus actuaciones, cuando éste cause un daño antijurídico a causa de un hecho, una omisión, una operación administrativa, la ocupación temporal o permanente de un inmueble, o cualquier otra causa como la actuación u omisión del poder legislativo, o la desaparición de un acto que irrogó perjuicios a unas personas determinadas.

A su turno, el profesor Santofimio Gamboa (2004: p. 211) define la reparación directa como

una acción de naturaleza subjetiva, individual, temporal y desistible, a través de la cual la persona que se crea lesionada o afectada (...) podrá solicitar directamente ante la jurisdicción de lo contencioso-administrativo que se repare el daño causado y se le reconozcan las demás indemnizaciones que correspondan. Se trata de una típica acción tendiente a indemnizar a las personas con ocasión de la responsabilidad extracontractual en que pudo incurrir el Estado. En el análisis jurídico de la acción de reparación directa opera el principio 'iura novit curia', en la medida que a la persona interesada no le corresponde presentar las razones jurídicas de sus pretensiones, sino simplemente relatar los hechos, omisiones, operación u ocupación, para que el juez administrativo se pronuncie con base en el derecho aplicable al caso.

En este orden de ideas, la reparación directa como medio de control de la actividad de la Administración, es la vía procesal adecuada para demandar la reparación del daño que deriva de un hecho, una omisión, una operación administrativa o la ocupación temporal o permanente de inmueble por causa de trabajos públicos, o por cualquiera otra causa, siempre que esta última no consista en un acto administrativo, porque 
cuando éste es fuente de un daño, la ley prevé expresamente como mecanismo de control pertinente la de nulidad y restablecimiento del derecho (art. 138 CPACA, art. 85 CCA).

En el decreto-ley 01 de 1984, la acción de reparación directa se encontraba prescrita en el inciso primero del artículo 86, modificado por el artículo 31 de la ley 446 de 1998, el cual señalaba:

"La persona interesada podrá demandar directamente la reparación del daño cuando la causa sea un hecho, una omisión, una operación administrativa o la ocupación temporal o permanente del inmueble por causa de trabajos públicos o por cualquiera otra causa".

De conformidad con el artículo 206 del Código Contencioso-Administrativo, dicha acción se tramitaba mediante el procedimiento ordinario descrito en los artículos 207 a 214 de dicho estatuto.

Entretanto, la legislación contencioso-administrativa vigente, Código Procesal Administrativo y de lo Contencioso-Administrativo (ley 1437 de 2011), en el artículo 140 consagra la reparación directa como medio de control de la actividad de la Administración en los siguientes términos:

En los términos del artículo 90 de la Constitución Política, la persona interesada podrá demandar directamente la reparación del daño antijurídico producido por la acción u omisión de los agentes del Estado.

De conformidad con el inciso anterior, el Estado responderá, entre otras, cuando la causa del daño sea un hecho, una omisión, una operación administrativa o la ocupación temporal o permanente de inmueble por causa de trabajos públicos o por cualquiera otra causa imputable a una entidad pública o a un particular que haya obrado siguiendo una expresa instrucción de la misma.

Las entidades públicas deberán promover la misma pretensión cuando resulten perjudicadas por la actuación de un particular o de otra entidad pública.

En todos los casos en los que en la causación del daño estén involucrados particulares y entidades públicas, en la sentencia se determinará la proporción por la cual debe responder cada una de ellas, teniendo en cuenta la influencia causal del hecho o la omisión en la ocurrencia del daño.

Ahora bien, con fundamento en el presupuesto "las formas propias de cada juicio", contenido en el artículo 29 de la Constitución Política, un proceso de manera general 
comprende el conjunto de reglas señaladas en la ley que, según la naturaleza del juicio, determinan los procedimientos o trámites que deben surtirse ante las diversas instancias judiciales o administrativas. Dichas reglas, en virtud de la cláusula general de competencia, deben ser fijadas por el legislador, quien, con el ánimo de brindarle a los ciudadanos medios idóneos y oportunidades de defensa de sus derechos, expide las pautas a seguir dentro de cada actuación procesal (Corte Const., sentencia C-652/97).

De este modo, las demandas de reparación directa impetradas con posterioridad al 2 de julio de 2012 deberán reunir los requisitos señalados en los artículos 159 a 167 de la Ley 1437 de 2011, previo agotamiento del requisito de procedibilidad en los términos descritos en los artículos 35 y 37 de la ley 640 de 2001.

Por su parte, el procedimiento a seguir es el descrito en los artículo 168 a 186 del Código Procesal Administrativo y de lo Contencioso-Administrativo, que se tramita de forma mayoritariamente oral.

Finalmente, cuando el juez administrativo profiere una sentencia de reparación directa (arts. 187 y ss., CPACA), esta produce efectos 'inter partes', es decir, que cuando la decisión es adversa al Estado Legislador, el mismo se encuentra obligada a pagar las condenas correspondientes (arts. 192, 193 y 195, CPACA). Es mediante una liquidación incidental (art. 193 CPACA) que el Estado Legislador deberá pagar la condena de frutos, intereses, mejoras y perjuicios, cuando la cuantía no se hubiere establecido en el proceso (Corte Const., sentencia C-644/11).

\subsection{OPORTUNIDAD PARA EJERCER EL DERECHO DE ACCIÓN POR RESPONSABILIDAD DEL ESTADO LEGISLADOR - CADUCIDAD}

La caducidad ha sido definida por la Corte Constitucional (Sentencia C-832/01), como "una institución jurídico-procesal a través de la cual el legislador, en uso de su potestad de configuración normativa, limita en el tiempo el derecho que tiene toda persona de acceder a la jurisdicción con el fin de obtener pronta y cumplida justicia".

En sentido general, Rozo Acuña (1986: p. 29) la define como "la pérdida de un derecho, acción, oportunidad, potestad o facultad, por haber expirado el plazo fijado, o 
los requisitos fijados por la ley para su ejercicio. No depende de la voluntad del titular de ese derecho o acción".

Entretanto, Acevedo Prada (2004: pp. 91-97) la entiende como "aquel fenómeno jurídico que limita en el tiempo el ejercicio de una acción o de una facultad, independientemente de consideraciones que no sean el sólo transcurso del tiempo".

Pues bien, el fundamento de dicha institución jurídico-procesal, se halla en la necesidad por parte del conglomerado social de obtener seguridad jurídica, para evitar la paralización del tráfico jurídico. En esta medida, la caducidad no concede derechos subjetivos, sino que por el contrario apunta a la protección de un interés general. La caducidad impide el ejercicio del derecho de acción, por lo cual, cuando se ha configurado no puede iniciarse válidamente el proceso. Ésta es una figura de orden público lo que explica su carácter irrenunciable, y la posibilidad de ser declarada de oficio por parte del juez, cuando se verifique su ocurrencia (Corte Const., sentencia C832/01).

La caducidad se produce tanto en el derecho privado como en el derecho público, y en ambos tiene carácter de orden público, y sólo puede actuar en los excepcionales casos que el legislador ha contemplado expresamente en la ley. De manera que si el actor deja transcurrir los plazos fijados por la ley en forma objetiva, el derecho, acción, oportunidad, facultad o potestad, fenecen inexorablemente, sin que pueda alegarse excusa alguna para revivirlos.

Además, es importante hacer alusión que el fenómeno jurídico-procesal bajo estudio, en el derecho administrativo, así como en las demás ramas del derecho donde el legislador lo ha establecido, opera 'ipso jure', vale decir que el operador judicial puede y debe declararla oficiosamente cuando verifique el hecho objetivo de inactividad en el lapso consagrado en la ley para cumplir con la oportunidad de hacer uso del derecho de acción. Dicha verificación es simple, puesto que es la ley que al señalar el plazo fatal y el momento de su iniciación, precisa el término final, el cual ni se interrumpe ni 
se prorroga, solamente pueden suspenderse en los términos y en las condiciones descritas en el artículo 21 de la ley 640 de 2001.

El fenómeno de la caducidad en el Derecho Administrativo, que por sus consecuencias obedece a la necesidad de obtener en tiempos breves la definición de ciertos asuntos, traduce la función que tiene la ley de ser una garantía para la efectividad de los principios constitucionales de la seguridad jurídica y de la prevalencia del interés general (Corte Const., sentencia C-401/10).

La justificación de la aplicación de la figura de la caducidad en materia contenciosoadministrativa, tiene como fundamento evitar la incertidumbre que podría generarse ya sea por la eventual anulación de un acto administrativo, o el deber que podría recaer sobre el Estado de reparar el patrimonio del particular afectado por una acción u omisión suya. Así, en esta materia, se han establecido plazos breves y perentorios 'pro tempore'- para el ejercicio de los mecanismos de control de la actividad de la Administración, transcurridos los cuales el derecho del particular no podrá reclamarse en consideración del interés general.

En lo concerniente a la reparación directa, la caducidad -aparte de las características y elementos antes anotados-, tiene como propósito fundamental propender por la diligencia del administrado, al señalarle un plazo perentorio -'pro tempore'-, que de manera general determina la ley para el efecto, para que pueda acudir a la jurisdicción de lo contencioso-administrativo a demandar al Estado por el daño antijurídico que presuntamente se le ha ocasionado.

El legislador -en ejercicio de su potestad de configuración normativa-, es autónomo para fijar los plazos o términos que tienen las personas para ejercitar sus derechos ante las autoridades tanto judiciales como administrativas competentes. En este punto, el margen de configuración del legislador es muy amplio, ya que no existe un parámetro estricto para poder determinar la razonabilidad de los términos procesales. La limitación de estos está dada por su fin, cual es permitir la realización del derecho 
sustancial. Al respecto, la Corte Constitucional (sentencia C-652/97) ha señalado, que "en virtud de la cláusula general de competencia, el legislador está ampliamente facultado para fijar los procedimientos judiciales $y$, en particular, los términos que conducen a su realización, siempre y cuando los mismos sean razonables y estén dirigidos a garantizar el derecho sustancial".

Pues bien, para la acción de reparación directa, el artículo 136 del Código ContenciosoAdministrativo (decreto-ley 01 de 1984), previó como término para presentar la demanda en ejercicio de dicha acción, el de dos años "contados a partir del día siguiente del acaecimiento del hecho, omisión y operación administrativa o de ocurrida la ocupación temporal o permanente del inmueble de propiedad ajena por causa de trabajo público o por cualquiera otra causa".

En igual forma, y atendiendo a la necesidad de organizar coherentemente diferentes instituciones procesales, el artículo 164, literal i del Código Procesal Administrativo y de lo Contencioso-Administrativo (Ley 1437 de 2011), consagra que la demanda de reparación directa deberá presentarse

"dentro del término de dos (2) años, contados a partir del día siguiente al de la ocurrencia de la acción u omisión causante del daño, o de cuando el demandante tuvo o debió tener conocimiento del mismo si fue en fecha posterior, y siempre que pruebe la imposibilidad de haberlo conocido en la fecha de su ocurrencia".

La ley consagra, entonces, un término de dos años contado desde el día siguiente al acaecimiento de la causa del daño por el cual se demanda indemnización, para intentar el medio de control de reparación directa, vencido el cual no será posible solicitar la declaratoria de responsabilidad patrimonial del Estado, porque habrá operado la caducidad.

La Ley 1437 de 2011, siguiendo la reiterada jurisprudencia de la Sección Tercera del Consejo de Estado (Autos del 30 de enero de 2003, del 27 de febrero de 2003, del 2 de febrero de 2005, del 11 de mayo de 2006, del 18 de julio de 2007, del 9 de abril de 2008), y en aplicación de los principios 'pro actioni' y 'pro damato', consagró en el literal i del artículo 164, que en algunos casos el término de caducidad debe empezar a 
contarse a partir de la fecha en que el interesado tuvo conocimiento del hecho que produjo el daño, que puede coincidir con la ocurrencia del mismo en algunos eventos, pero en otros casos no.

\subsection{REFLEXIÓN}

En Colombia, la actual Carta Fundamental ha dado un paso firme en la consolidación y en la constitucionalización de la responsabilidad patrimonial del Estado Legislador, lo cual ha hecho a través de un conjunto de normas de mayor rigor técnico, amplias y diáfanas, como los artículos 1, 2, 4, 6, 13, 90 y 95 superiores.

Así las cosas, teniendo el carácter de 'norma normarum', la Carta Fundamental de 1991 (art. $4^{\circ}$ ) ha proyectado la institución de la responsabilidad del Estado Legislador a nivel ciudadano y jurisprudencial, con ingentes efectos sociales y jurídicos tanto en lo sustancial como en lo adjetivo.

Dentro de este contexto, tanto la jurisprudencia de la Corte Constitucional como del Consejo de Estado han advertido que, si bien el legislador tiene libertad de configuración y de regular o desarrollar todas aquellas materias necesarias para la existencia de la organización política, obviamente en el ejercicio de esa potestad la función legislativa del Congreso está sujeto al bloque de constitucionalidad representado por los preceptos, valores, principios y jurisprudencia constitucionales.

En efecto, la jurisprudencia contencioso-administrativa en sentencias del Consejo de Estado del 25 de agosto de 1998, proferida por la Sala Plena de lo ContenciosoAdministrativo dentro de la reparación directa de número IJ-001 -demandante Vitelvina Rojas Robles y otros, demandado Ministerio de Relaciones Exteriores y el Congreso de la República, representado por el Ministerio del Interior, del 26 y del 27 de marzo de 2014, proferidas por la Sección Tercera, en su orden, dentro de los expedientes No. 25000-23-26-000-2003-00175-01 (28.741) y 25000-23-26-000-2002-02117-01(29146)-, ha aceptado la responsabilidad del Estado Legislador en Colombia, por eventos o 
supuestos diferentes a los descritos en los artículos 58, 336 y 365 de la Constitución Política, estableciendo además el título de imputación de la responsabilidad estatal aplicable. 


\section{CONCLUSIONES}

En los Estados que se han encontrado regidos bajo el principio de la soberanía política del legislador, resulta inusitada la responsabilidad del Estado por actos, hechos y omisiones de legislación. Sin embargo, ese principio entró en colisión con el de la supremacía del derecho, característico del constitucionalismo y del estado de derecho.

La institución jurídica de la responsabilidad del Estado Legislador, cobró fuerza si se tiene en cuenta que a partir de la corriente que surge con posterioridad a la Segunda Guerra Mundial (1939-1945), se abandonó la sacralización hacia la figura del legislador, otorgándole preponderancia a la Constitución sobre las demás normas del ordenamiento jurídico, lo cual es lógico, debido a que no puede desconocerse que, conforme a los más elementales principios del derecho constitucional, el Congreso es tan sólo el constituyente derivado, mientras que la Carta Política personifica la voluntad del constituyente primario, quien es -en últimas- el verdadero soberano.

De este modo, se advierte que la Constitución establece expresamente determinados supuestos de obligación reparatoria por la actuación del Legislador, tales como la figura de la expropiación, la obligación de indemnizar cuando se establece un monopolio o cuando el Estado decide reservarse determinadas actividades estratégicas o servicios públicos. Estos principios que cristalizaron en el ordenamiento jurídico-constitucional colombiano, y que encontraron sus expresiones en los artículos 58, 336 y 365 de la Carta Fundamental.

No obstante, ello no significa que la responsabilidad del Estado Legislador se vea circunscrita exclusivamente a los anteriores eventos o a los supuestos de declaratoria de inconstitucionalidad de las leyes, pues su fundamento estriba en la noción de daño antijurídico, la cual descansa en los principios de solidaridad y de igualdad, y no en la idea de la actividad ilícita del Legislador, entendida como tal las actuaciones contrarias a la Constitución. 
Justamente, el artículo 90 de la Carta Política -disposición constitucional que regula la materia-, establece la obligación de reparar los daños antijurídicos provenientes de cualquier autoridad pública. En consecuencia, como se ha reiterado, el precepto superior solamente establece dos requisitos para que opere la responsabilidad patrimonial estatal, a saber, que haya un daño antijurídico y que éste sea imputable a una acción u omisión de una autoridad pública, sin efectuar diferenciaciones o exclusiones con respecto al causante del daño.

De este modo, la responsabilidad patrimonial del Estado por los hechos, acciones $u$ omisiones imputables al Poder Legislativo está expresamente contemplada en el artículo 90 constitucional, pues cualquier otra posibilidad sería abiertamente inconstitucional desde la perspectiva del Estado Social de Derecho y de los principios y valores que rigen el ordenamiento jurídico colombiano, tales como la solidaridad, la igualdad, la justicia material y la supremacía de la Constitución.

En efecto, en nuestro país los eventos de responsabilidad legislativa constitucionalmente establecidos no son los únicos, puesto que dentro del desarrollo jurisprudencial contencioso-administrativo, se ha distinguido que el deber reparatorio se puede edificar sin la necesidad de un previo juicio declarativo de invalidez de la ley dañosa. Entretanto, un segundo grupo de casos se construye, justamente con fundamento en la declaratoria de inconstitucionalidad de las leyes.

Esta diferencia ha motivado a la doctrina y a la jurisprudencia a consolidar la distinción, entre dos hipótesis genéricas de Responsabilidad del Estado Legislador: 1) La responsabilidad del Estado Legislador por leyes declaradas inconstitucionales, y 2) responsabilidad derivada de los actos legislativos conformes al ordenamiento constitucional.

Así las cosas, debe apreciarse que el hecho dañoso idóneo para activar esta forma de responsabilidad patrimonial del Estado, es un perjuicio directamente producido por una ley en su aplicación, no por la aplicación misma de ésta. 
De otro lado, en el ordenamiento jurídico positivo colombiano, se le ha reconocido competencia al legislador y a la jurisprudencia de lo contencioso-administrativo como fuentes determinadoras de otros supuestos y de los títulos de imputación en materia de responsabilidad del Estado Legislador.

Ciertamente, determinar el régimen particular de la responsabilidad del Estado Legislador -o si se prefiere los títulos de imputación del daño antijurídico a la actuación u omisión del Congreso de la República-, es una tarea que en todo caso corresponde precisar al propio Legislador en ejercicio de su potestad configuradora y a la jurisprudencia contencioso-administrativa, como juez especializado en la materia. Sobre el particular, la jurisprudencia contencioso-administrativa en sentencias del Consejo de Estado del 25 de agosto de 1998, proferida por la Sala Plena de lo Contencioso-Administrativo dentro de la reparación directa de número IJ-001 [demandante: Vitelvina Rojas Robles y otros; demandado: Ministerio de Relaciones Exteriores y el Congreso de la República, representado por el Ministerio del Interior, y del 26 y del 27 de marzo de 2014, proferidas por la Sección Tercera, en su orden, dentro de los expedientes No. 25000-23-26-000-2003-00175-01 (28.741) y 25000-2326-000-2002-02117-01(29146)], le ha dado vida a la responsabilidad del Estado Legislador en Colombia, por eventos o supuestos diferentes a los descritos en los artículos 58, 336 y 365 de la Carta Fundamental. La primera de las providencias enunciadas, esto es, la proferida el 25 de agosto de 1998, esbozó como título de imputación de la responsabilidad estatal por el hecho del legislador, el daño especial; entretanto, en los proveídos del 26 y del 27 de marzo de 2014, el Consejo de Estado, Sección tercera adoptó como título de imputación la falla en el servicio.

Adicionalmente, la jurisprudencia tanto de la Sala Plena de lo ContenciosoAdministrativo del Consejo de Estado como de la Sección Tercera de la misma Corporación de Justicia, ha reiterado que la vía procesal para reclamar los daños 
antijurídicos provenientes de la actuación u omisión del poder legislativo es la acción de reparación directa. 


\section{REFERENCIAS}

Acevedo Prada, L.A. (2004). Caducidad, Prescripción, Perención, Preclusión y Términos. Bogotá D.C., Colombia: Ediciones Jurídica Radar.

Alessi, R. (1970). Instituciones de Derecho Administrativo. (Trad. B. Pellisé Prats). Barcelona, España: Bosch, Casa Editorial.

Alonso García, M.C. (1999). La responsabilidad patrimonial del Estado Legislador. Madrid, España: Marcial Pons, Ediciones Jurídicas y Sociales.

Amalfi Álvarez, L.R.\& Cala Moncaleano, G. (1984). La responsabilidad del Estado Legislador. (Tesis de Grado de Derecho, no publicada). Bogotá D.C., Colombia: Universidad del Rosario.

Aylwin Azocar, P. (1960). Derecho Administrativo. Santiago de Chile : Editorial Universitaria.

Barnés Vásquez, J. (1995). El derecho de propiedad en la Constitución española de 1978. Propiedad, expropiación y responsabilidad. La garantía indemnizatoria en el derecho europeo y comparado. Madrid : Tecnos.

Berberoff Ayuda, D. \& Sospedra Navas, F. (2006). Fundamentos dogmáticos de la responsabilidad patrimonial de la administración en la jurisprudencia. Madrid : Consejo General del Poder Judicial, Fundación Wellington.

Bielsa, R. (1938). Derecho Administrativo. Buenos Aires : J. Lajoane.

Bullrich, R. (1920). La responsabilidad del Estado. Buenos Aires : J. Méndez. 
Bustamante Ledesma, Á. (2003). La Responsabilidad Extracontractual del Estado. Bogotá, D.C. : Leyer. 2a ed.

Cabanellas de Torres, G. (1984). Diccionario Jurídico Elemental. Buenos Aires : Heliasta S.R.L. 2a ed.

Caldera Delgado, H. (1982). Sistema de responsabilidad extracontractual del Estado en la Constitución Política de 1980. Santiago de Chile : Editorial Jurídica de Chile

Canasi, J. (1972). Derecho Administrativo. Buenos Aires : Editorial Depalma.

Carrillo Flores, A. (1987). Estudios de Derecho Administrativo y Constitucional. México D.C. : UNAM.

------. (1973). La justicia federal y la administración pública. México D.F. : Porrúa.

Cassagne, J.C. (2002). Derecho Administrativo.(7- Ed). Buenos Aires : Lexis Nexis, Abeledo Perrot. $7^{\mathrm{a}}$ Ed.

Castellot Rafful, R.A. (2000). La Unión Europea: Una experiencia de integración regional. México D.F. : Plaza y Valdés Editores. 2da. Ed

Castillo Blanco, F.A. (1998). La protección de la confianza en el Derecho Administrativo. Madrid : Marcial Pons, Ediciones Jurídicas y Sociales.

Cazorla Prieto L.M. (1985). Las Cortes Generales: ¿Parlamento contemporáneo?. Madrid : Editorial Civitas, S.A.

Celdrán Ruano, J. (1996). La responsabilidad del Estado por actos de aplicación de leyes: Aproximación histórica y significado actual. Murcia (España) : Universidad de Murcia. 
Cepeda, M.J. (1992) Los derechos fundamentales en la Constitución de 1991. Santafé de Bogotá D.C.

Checa González, C. (2004). La responsabilidad patrimonial de la Administración Pública con Fundamento en la Declaración de inconstitucionalidad de una Ley. Revista lus et Praxis, año 10, No. 10.

Colombo, L.A. (1947). Culpa Aquiliana (cuasidelitos). Buenos Aires : La Ley.

Da Silva Santos Filho, I. (2012). La Responsabilidad del Estado Legislador por las Leyes Tributarias inconstitucionales y el enriquecimiento sin causa. (Tesis de Grado Doctorado en Derecho). Salamanca (España) : Universidad de Salamanca.

Diez, M.M. Derecho Administrativo (1971). Buenos Aires : Editorial Plus Ultra.

Dromi, J. R. (1979). Derecho administrativo económico. Buenos Aires : Editorial Astrea.

Embid Irujo, A. (1982). La codificación de la responsabilidad patrimonial del Estado: el ejemplo de la Ley alemana de 26 de junio de 1981. Revista Española de Derecho Administrativo, No. 34. Madrid (España).

Fiorini, B. (1968). Manuel de Derecho Administrativo. Buenos Aires : La Ley.

Forsthoff, E. (1958). Tratado de Derecho Administrativo. Madrid : Instituto de Estudios Políticos. Traducido por Legaz y Lacambra, Garrido Falla, Gómez de Ortega y Junge.

Galán Vioque, R. (2001, mayo-agosto). De la teoría a la realidad de la responsabilidad del Estado legislador. Revista de Administración Pública, №155. 
------. (2001). La responsabilidad del Estado Legislador. Barcelona : Cedecs Editorial S.L.

Galindo Vacha, J.C. (2006). Lecciones de Derecho Procesal administrativo. Bogotá D.C. : Pontifica Universidad Javeriana. $2^{\mathrm{a}}$ Ed.

Gamba Ladino, J.C. (2005). Responsabilidad del Estado Legislador. En: Cienfuegos Salgado, D. \& López Olvera, M. A. Estudios Homenaje a Don Jorge Fernández Ruiz. México: UNAM.

García-Álvarez, G. (2009). La responsabilidad patrimonial de los poderes públicos. Bermejo Vera (Dir.) Derecho administrativo: parte especial. Madrid : Thomson-Civitas. $7^{\mathrm{a}} \mathrm{Ed}$.

García de Enterría, E. (2005). La garantía del patrimonio de los ciudadanos: expropiación forzosa y responsabilidad patrimonial del legislador en el derecho comparado. Responsabilidad patrimonial del Estado legislador en el derecho español. Madrid : Editorial Aranzadi.

-------. (2007). La responsabilidad patrimonial del Estado Legislador en el Derecho español. Madrid : Thomson Civitas.

-------. (2005). Las expropiaciones legislativas desde la perspectiva constitucional. En particular, el caso de la Ley de Costas, publicado en la responsabilidad patrimonial del Estado legislador en el derecho español. Madrid : Editorial Aranzandi.

------. (1956). Los principios de la nueva ley de expropiación forzosa: potestad expropiatoria, garantía patrimonial, responsabilidad civil de la administración. Madrid : Instituto de Estudios Políticos. 
García de Enterría, E., \& Fernández, T.R. (1981). Curso de Derecho Administrativo. Madrid : Editorial Civitas, S.A.

García Luengo, J. (1998). El Principio de protección de la confianza en el Derecho Administrativo. Madrid : Editorial Civitas, S.A.

García Mendoza, H. (1997). La responsabilidad extracontractual del Estado. Santiago de Chile : Editorial Jurídica Conosur.

Garrido Falla, F. (1993). La responsabilidad patrimonial del Estado legislador en la nueva Ley 30/1992 y en la sentencia del Tribunal Supremo de 30 de noviembre de 1992. Revista Española de Derecho Administrativo, No. 77.

------. (1989, enero). Sobre la Responsabilidad del Estado Legislador. En: Revista de Administración Pública.

Garrido Mayol, V. (2004). La Responsabilidad Patrimonial del Estado. Valencia, España: Tirant lo Blanch.

Garzón Clariana, G. (1993). Las fuentes del derecho Comunitario. En: Rodríguez Iglesias, G.C., \& Liñan Nogueras, D.J. (Dir.) El Derecho comunitario europeo y su aplicación judicial. Madrid : Editorial Civitas, S.A..

Gil Botero, E. (2011). Responsabilidad Extracontractual del Estado. Bogotá D.C.: Editorial Temis. 5ํㅡ. Ed.

Gómez Pavajeau, C.A. (2011). La dogmática jurídica como ciencia del derecho: Sus especies penal y disciplinaria necesidad, semejanzas y diferencias. Bogotá D.C.: Universidad Externado de Colombia. 
Henao Hidrón, J. (2006). Derecho Procesal Constitucional. Protección de los derechos constitucionales. Bogotá D.C. : Editorial Temis. 2a Ed.

------. (1994). Panorama del Derecho Constitucional Colombiano. Santa Fe de Bogotá D.C. : Editorial Temis. 9ํㅡ. Ed.

Hoyos Duque, R.I. (1984). La responsabilidad patrimonial de la administración pública. Bogotá D.C. : Editorial Temis.

Ibáñez Najar, J. E. (2006). El Derecho Público Colombiano. En: V Foro Iberoamericano de Derecho Administrativo: El Marco Constitucional del Derecho Administrativo en Iberoamérica. Quito, Ecuador: Colegio de Jurisprudencia USFQ.

Jeze, G.P.A. (1949). Principios Generales del Derecho Administrativo. (Trad. J.N. San Millán Almagro). Buenos Aires : Editorial Depalma.

Jiménez Lechuga F.J. (1999). La Responsabilidad Patrimonial de los Poderes Públicos en el Derecho Español: Una visión de conjunto. Madrid : Marcial Pons Ediciones Jurídicas y Sociales S.A.

Leguina Villa, J. (1992). Coloquio sobre el proyecto de Ley de Régimen Jurídico de las Administraciones Públicas y del Procedimiento Administrativo común. Coordinación por Francisco López Menudo, Córdoba (España) : Universidad de Córdoba.

------. (1993). La Responsabilidad Patrimonial de la Administración en la nueva Ley de Régimen Jurídico de las Administraciones Públicas y del procedimiento Administrativo Común. Madrid : Editorial Civitas S.A.

-----. (1983). La responsabilidad civil de la administración pública: su formulación en el Derecho italiano y análisis comparativo con los ordenamientos francés y español. Madrid : Editorial Tecnos. $2^{\mathrm{a}}$ Ed. 
-------. (2000). Origen y evolución de la responsabilidad patrimonial del Estado. La Responsabilidad Patrimonial del Estado: Memoria del Seminario Internacional sobre la Responsabilidad Patrimonial del Estado. México D.F.: Instituto Nacional de Administración Pública.

Leiva Ramírez, E. (2010). Responsabilidad del Estado por el hecho del legislador: análisis jurisprudencial y doctrinal. Bogotá D.C. : Grupo Editorial Ibáñez.

Linares Quintana, S.V. (1946). Gobierno y Administración de la República Argentina. Buenos Aires : Tipográfica Editora Argentina.

Long, M.; Weil, P.; Braibant, G.; Delvolvé, P. \& Genevois, B. (2009). Los grandes fallos de la jurisprudencia administrativa francesa. (Trad. L. Torres, H. Osejo, revisado M.L. Crepy). Bogotá D.C.: Ediciones Librería del Profesional. 2ª Ed.

López Morales, J. (2001). Responsabilidad Patrimonial del Estado. Evolución de la Jurisprudencia colombiana. Santa Fe de Bogotá : Ediciones Doctrina y Ley Ltda.

Marienhoff, M. S. (1987). Tratado de Derecho Administrativo. Buenos Aires : Editorial Abeledo-Perrot.

Mariño Menéndez, F.M. (1995). El Tratado de la Unión Europea: Análisis Jurídico. Madrid : Secretaría General Técnica, Ministerio de Justicia e Interior.

Martín Queralt, J. (2008). La ejecución de las Sentencias del Tribunal de Justicia de las Comunidades Europeas: las peticiones de devolución y las acciones de resarcimiento. Análisis de la jurisprudencia tributaria comunitaria: su incidencia en los tribunales españoles. Madrid: Consejo General del Poder Judicial, Centro de Documentación Jurídica. 
Muñoz Machado, S. (1993). La Unión Europea y las mutaciones del Estado. Madrid : Alianza Editorial.

Naranjo Mesa, V. (1995). Teoría Constitucional e Instituciones Políticas. Santa Fe de Bogotá D.C. : Editorial Temis. 6를

Navarro Fernández, P. F. (2010). La responsabilidad patrimonial del estado legislador en el derecho financiero y tributario español. Responsabilidad del Estado por Actos de Contenido Tributario. XXV Jornadas Latinoamericanas de Derecho Tributario Cartagena de Indias-Colombia. Buenos Aires : Editorial Abeledo Perrot.

Nieto, A. (1962). Evolución expansiva del concepto de expropiación forzosa. Revista de Administración Pública, No. 38.

Núñez Leiva, J. I. (2008). Antecedentes de la responsabilidad patrimonial del Estado legislador y su aplicación al caso chileno. Revista de Derecho de la Universidad Católica de Uruguay, № 03.

-------. (2010). La responsabilidad patrimonial del Estado Legislador: Un análisis a propósito de las garantías del contribuyente en el sistema chileno. Estudios Constitucionales de Chile. Talca (Chile): Universidad de Talca.

------. (2011). Responsabilidad Patrimonial del Estado Legislador: Distinguiendo. Revista de Derecho, No. 35. Barranquilla (Colombia) : Universidad del Norte.

-------. (2011). Responsabilidad Patrimonial del Estado Legislador y Sentencia de Inconstitucionalidad: Análisis del caso chileno. VIII Congreso Mundial de la Asociación Internacional de Derecho Constitucional, en la mesa temática XIII: Nuevas tendencias del derecho constitucional en América Latina. 
Oliva Santos, A. de la. (1989). La STC Pleno 45/1989 (IRPF y declaración conjunta de los casados): una legislación retroactiva y, de nuevo, el principio de igualdad en entredicho. Madrid : La Ley.

Parada, R. (1993). Derecho Administrativo: Parte General. Madrid : Marcial Pons, Ediciones Jurídicas, S.A. $5^{\mathrm{a}}$ Ed..

Petit, E. (1994). Tratado Elemental de Derecho Romano. (Trad. J. Fernández González). Buenos Aires : Abogados Asociados Editores. 9aㅡ Ed.

Pineda, F. (1984). Responsabilidad del Estado. En: Diccionario Jurídico Mexicano. México D.F. : UNAM.

Penagos Vargas, G. (1997). El daño antijurídico: aplicación del principio 'iura novit curia'. Santafé de Bogotá D.C. : Librería Doctrina y Ley.

Pérez González, C. (2001). La responsabilidad del Estado frente a particulares por incumplimiento del derecho comunitario. Valencia (España): Tirant lo Blanch.

Pia Larné, M. (2008). Intento de comparación entre los modelos alemán, francés y español de responsabilidad del Estado: ¿Existe una responsabilidad del Legislador? Revista de la Facultad de Derecho de México, No. 249. México D.F.: UNAM.

Quintana López, T. (1994). La responsabilidad del Estado legislador. Revista de Administración Pública, No. 135.

Real Academia de la Lengua Española. (2001). Diccionario de la Lengua Española. Madrid : Editorial Espasa Calpe S.A. 22를 Ed.

Retis Amaya, J.M. (2005). Las teorías del riesgo excepcional y el daño especial en la responsabilidad del Estado. Conferencia sobre la evolución de la responsabilidad 
estatal en Colombia. Acta de la Conferencia sobre la Responsabilidad Estatal en Colombia. Bogotá D.C.: Colegio de Abogados de la Universidad Católica de Colombia.

------. (2005). La responsabilidad del Estado legislador. Conferencia sobre la evolución de la responsabilidad estatal en Colombia. Acta de la Conferencia sobre la Responsabilidad Estatal en Colombia. Bogotá D.C. : Colegio de Abogados de la Universidad Católica de Colombia.

Rivero, J. (1984). Derecho Administrativo. Caracas: Universidad Central de Venezuela.

Rodríguez R., L. (1995). Derecho Administrativo general y colombiano. Santa Fe de Bogotá D.C.: Editorial Temis. 8를.

Rojas, J.G. (2005). Críticas al sistema de acciones procesales en el derecho administrativo colombiano. En: Memorias de las V Jornadas de Derecho Constitucional y Administrativo. Los procesos ante las jurisdicciones constitucional y de lo contencioso-administrativo. Bogotá D.C., Colombia: Universidad Externado de Colombia.

Rozo Acuña, E. (1986). Diccionario de Política y Derecho público. Bogotá : Escuela Superior de Administración Pública.

Ruiz-Jarabo Colomer, D. (1997). El papel del juez nacional en la aplicación del Derecho comunitario. Cuadernos Europeos de Deusto (España), No. 6.

Ruiz López, M.Á. (2013). La Responsabilidad Patrimonial del Estado-Legislador en el Derecho español. Madrid : La Ley, No. 8152.

Ruiz Orejuela, W. (2011). Responsabilidad del Estado Legislador. Bogotá D.C.: Universidad Libre. 
------. (2005). Responsabilidad del Estado Legislador. En: Revista Civilizar, No. 9. Bogotá D.C. : Universidad Sergio Arboleda.

------.. (2008). Responsabilidad extracontractual. Bogotá D.C. : Ecoe Ediciones.

Sáinz Moreno, F. (1982). El Tribunal Constitucional alemán declara la nulidad de la Ley de responsabilidad patrimonial del Estado, de 26 de junio de 1981. En: Revista de Administración Pública, No. 98. Madrid (España).

Santamaría Pastor, J.A. (1972). La teoría de la responsabilidad del Estado Legislador. En: Revista de Administración Pública, No. 68.

Santofimio Gamboa, J.O. (2005). Panorama General del Derecho Administrativo en Colombia. En: González-Varas Ibáñez, S. El Derecho Administrativo Iberoamericano, No. 9. Granada, España: Instituto Nacional de Administración Pública.

------. (2004). Tratado de Derecho Administrativo. Bogotá D.C.: Universidad Externado de Colombia, T. III.

Sarmiento Ramírez-Escudero, D. (2012). La aplicación del Derecho de la Unión por el Tribunal Supremo en tiempos de crisis. Madrid : Instituto de Derecho Europeo e Integración Regional (IDEIR) - Universidad Complutense.

Sayagués Laso, E. (1963). Tratado de Derecho Administrativo. Montevideo : Talleres Gráficos Barreiro y Ramos S.A..

Segura Serrano, A. (2010). Los acuerdos comerciales regionales y bilaterales. Derecho Internacional Económico. Madrid : Marcial Pons, Ediciones Jurídicas y Sociales.

Serra Rojas, A. (1973). Derecho Administrativo. México D.F. : Editorial Porrúa. 5ª Ed. 
Serrano, J.L. (1999). Validez y Vigencia: La aportación garantista a la teoría de la norma jurídica. Madrid : Editorial Trotta.

Solís, J. A. (1995). Fundamentos y políticas de la Unión Europea. Madrid : Siglo XXI.

Soriano García, J. E. (1993). Desregulación, Privatización y Derecho Administrativo. Bolonia (Italia) : Publicaciones del Real Colegio de España.

-----. (1981). Responsabilidad del Estado legislador y proceso descolonizador. En: Revista Española de Derecho Administrativo.

Soto Kloss, E. (1996). Derecho Administrativo: Bases y Fundamentales. Santiago de Chile : Editorial Jurídica de Chile.

Suárez García, J. (1999) Responsabilidad del Estado Legislador en la Responsabilidad patrimonial de las Administraciones Públicas. Xunta de Galicia (España) : Colecciones Jornadas y Seminarios, No. 22.

Tajadura Tejada, J. (2007). El principio de solidaridad en el Estado Autonómico. En: Cuadernos de Derecho Público, No. 32. Madrid : Inap.

Tamayo y Salmoran, R. (1984). Responsabilidad. En: Diccionario Jurídico Mexicano. México D.F. : UNAM.

Torregroza Sánchez, J. E. (2007). Responsabilidad extracontractual del Estado por el hecho del legislador. Bogotá D.C. : Universidad Externado de Colombia.

Vázquez Ferreyra, R.A. (1993). Responsabilidad por daños (elementos). Buenos Aires: Editorial Depalma. 
Vedel, G. (1980). Derecho Administrativo. (Trad. J. Rincón Jurado). Madrid : Biblioteca Jurídica Aguilar.

Vidal Perdomo, J. (2004). Derecho Administrativo. Universidad del Rosario, Bogotá, D. C. : Editorial Legis S.A. $12^{\text {a }}$ Ed.

Vidal Perdomo, J., Díaz Perilla, V. \& Rodríguez, G. A. (2005). Temas de Derecho Administrativo Contemporáneo. Bogotá D.C. : Universidad del Rosario.

Xiol Ríos, J. A. (2007). La responsabilidad patrimonial por acto legislativo. En: Moreno Martínez, J. A. La responsabilidad civil y su problemática actual. Madrid : Editorial Dykinson.

Younes Moreno, D. (1994). Curso Elemental de Derecho Administrativo. Santafé de Bogotá D.C. : Ediciones Jurídicas Gustavo Ibáñez. 4a Ed.

Zúñiga Urbina, F. (2005). Responsabilidad patrimonial del Estado Legislador. Santiago de Chile : Editorial Lexis Nexis.

\section{REFERENCIAS JURISPRUDENCIALES}

Alemania, Reichsgericht -RG - Tribunal del Imperio. Sentencia del 18 de noviembre de 1921.

-------. Sentencia del 22 de febrero de 1924.

-------. Sentencia del 13 de diciembre de 1924.

-------. Sentencia del 11 de marzo de 1927.

-------. Sentencia del 11 de abril de 1933. 
Chile, Corte de Apelaciones de Santiago. Sentencia del 31 de noviembre de 2003, caso Sociedad Agrícola Lolco Ltda. contra el Fisco de Chile, Rol N 6828-1999.

Chile, Corte Suprema de Justicia. Sentencia del 7 de agosto de 1984, caso Comunidad Galletué contra el Fisco de Chile, Rol № 16.743-1984.

Chile, Tribunal Constitucional. Sentencia del 18 de junio de 2004, caso Sociedad Inmobiliaria Maullín Ltda. contra el Fisco de Chile", Rol № 4309-2002.

-------. Sentencia del 2 de diciembre de 1996, caso Playas, Rol № 245-246/1996 (acumulados).

Colombia, Consejo de Estado. Sala de lo Contencioso-Administrativo. Sentencia del 27 de julio de 1947, C.P. Dr. Gustavo A Valbuena. En: Anales del Consejo de Estado, T. LVI, Nos. 357-361.

------. Sala de lo Contencioso-Administrativo. Sección Tercera. Auto del 30 de enero de 2003, expediente 22.688, C.P. Dr. Ramiro Saavedra Becerra.

------. Sala de lo Contencioso-Administrativo. Sección Tercera. Auto del 27 de febrero de 2003, expediente 23.446, C.P. Dra. María Elena Giraldo Gómez

-------. Sala de lo Contencioso-Administrativo. Sección Tercera. Auto del 2 de febrero de 2005, expediente 27.994, C.P. Dra. María Elena Giraldo Gómez.

-------. Sala de lo Contencioso-Administrativo. Sección Tercera. Auto del 11 de mayo de 2006, expediente 30.325, C.P. Dr. Ramiro Saavedra Becerra.

-------. Sala de lo Contencioso-Administrativo. Sección Tercera. Auto del 18 de julio de 2007, expediente 30.512, C.P. Dr. Ramiro Saavedra Becerra. 
-----. Sala de lo Contencioso-Administrativo. Sección Tercera. Auto del 9 de abril de 2008, expediente 33834, C.P. Dr. Ramiro Saavedra Becerra.

------. Sala de lo Contencioso-Administrativo. Sección Tercera. Sentencia del 28 de octubre de 1976, expediente No. 1482, C.P. Dr. Jorge Valencia Arango.

------. Sala de lo Contencioso-Administrativo. Sección Tercera. Sentencia del 2 de febrero de 1984, expediente No. 2744, C.P. Dr. Eduardo Suescún.

-------. Sala de lo Contencioso-Administrativo. Sección Tercera. Sentencia del 8 de marzo de 1984, expediente No. 2846, C.P. Dr. Eduardo Suescún.

-------. Sala de lo Contencioso-Administrativo. Sección Tercera. Sentencia del 20 de febrero de 1989, expediente No. 4655, C.P. Dr. Antonio José Irisarri Restrepo.

------. Sala de lo Contencioso-Administrativo. Sección Tercera. Sentencia del 28 de abril de 1989, expediente No. 3852, C. P. Dr. Carlos Betancur Jaramillo

------. Sala de lo Contencioso-Administrativo. Sección Tercera. Sentencia del 31 de julio de 1989, expediente No. 2852 (252), C.P. Dr. Antonio José de Irisarri Restrepo.

-------. Sala de lo Contencioso-Administrativo. Sección Tercera. sentencia del 24 de octubre de 1990, expediente No. 5902, C.P. Dr. Gustavo De Greiff Restrepo.

-------. Sala de lo Contencioso-Administrativo. Sección Tercera. Sentencia del 24 de abril de 1991, expediente No. 6110, C.P. Dr. Policarpo Castillo Dávila

------. Sala de lo Contencioso-Administrativo. Sección Tercera. Sentencia del $1^{\circ}$ de agosto de 1991, C.P. Dr. Juan de Dios Montes Hernández. 
------. Sala de lo Contencioso-Administrativo. Sección Tercera. Sentencia del 22 de noviembre de 1991, expediente No. 6784, C. P. Dr. Julio César Uribe Acosta.

------. Sala de lo Contencioso-Administrativo. Sección Tercera. Sentencia del 30 de julio de 1992, expediente No. 6897, C.P. Dr. Daniel Suárez Hernández

-------. Sala de lo Contencioso-Administrativo. Sección Tercera. Sentencia del 24 de agosto de 1992, expediente No. 6754, C.P. Dr. Carlos Betancur Jaramillo.

-----. Sala de lo Contencioso-Administrativo. Sección Tercera. Sentencia del 25 de febrero de 1993, expediente No. 7742, C.P. Dr. Carlos Betancur Jaramillo

-------. Sala de lo Contencioso-Administrativo. Sección Tercera. Sentencia del 17 de junio de 1993, expediente No. 7716, C.P. Dr. Julio César Uribe Acosta.

------. Sala de lo Contencioso-Administrativo. Sección Tercera. Sentencia del 13 de julio de 1993, expediente No. 8163, C.P. Juan de Dios Montes Hernández.

------. Sala de lo Contencioso-Administrativo. Sección Tercera. Sentencia del 17 de febrero de 1994, expediente No. 8377, C.P. Dr. Carlos Betancur Jaramillo.

-------. Sala de lo Contencioso-Administrativo. Sección Tercera. Sentencia del 19 de abril de 1994, expediente No. 7096, C.P. Dr. Juan de Dios Montes.

-------. Sala de lo Contencioso-Administrativo. Sección Tercera. Sentencia del 16 de julio de 1994, expediente No. 8965, C.P. Dr. Daniel Suárez Hernández.

-------. Sala de lo Contencioso-Administrativo. Sección Tercera. Sentencia del 3 de noviembre de 1994, expediente No. 7310, C.P. Dr. Juan de Dios Montes. 
-------. Sala de lo Contencioso-Administrativo. Sección Tercera. Sentencia del 8 de mayo de 1995, expediente 8118, C.P. Dr. Juan de Dios Montes Hernández.

------. Sala de lo Contencioso-Administrativo. Sección Tercera. Sentencia del 13 de febrero de 1997, expediente No. 9912, C.P. Dr. Ricardo Hoyos Duque.

-------. Sala de lo Contencioso-Administrativo. Sección Tercera. Sentencia del 25 de septiembre de 1997, expediente No. 10392, C.P. Dr. Jesús María Carrillo.

------. Sala de lo Contencioso-Administrativo. Sección Tercera. Sentencia del 28 de agosto de 1998, C.P. Dr. Jesús María Carrillo.

-------. Sala de lo Contencioso-Administrativo. Sección Tercera. Sentencia del 21 de octubre de 1999, expediente No. 11815, C.P. Dr. Germán Rodríguez Villamizar.

------. Sala de lo Contencioso-Administrativo. Sección Tercera. Sentencia del 27 de julio de 2000, expediente No. 12168, C.P. Dr. Germán Rodríguez Villamizar.

-------. Sala de lo Contencioso-Administrativo. Sección Tercera. Sentencia del 15 de marzo de 2001, expediente No. 11222, C.P. Dr. Alier Eduardo Hernández Enríquez.

-------. Sala de lo Contencioso-Administrativo. Sección Tercera. Sentencia del 15 de marzo de 2001, expediente No. 11162, C.P. Dr. Alier E. Hernández Enríquez.

-------. Sala de lo Contencioso-Administrativo. Sección Tercera. Sentencia del 3 de mayo de 2001, expediente No. 05001-23-31-000-1992-1670-01(12338). C.P. Dr. Alier Eduardo Hernández Enríquez.

-----. Sala de lo Contencioso-Administrativo. Sección Tercera. Sentencia del 10 de mayo de 2001, expediente No. 20001-23-31-000-1993-0273-01(11783). C.P. Dr. Jesús María Carrillo Ballesteros. 
------. Sala de lo Contencioso-Administrativo. Sección Tercera. Sentencia del 14 de junio de 2001, expediente No. 12696, C.P. Dr. Alier Eduardo Hernández Enriquez.

------. Sala de lo Contencioso-Administrativo. Sección Tercera. Sentencia del 9 de agosto de 2001, expediente No. 12998, C.P. Dra. María Elena Giraldo Gómez.

------. Sala de lo Contencioso-Administrativo. Sección Tercera. Sentencia del 14 de marzo de 2002, expediente No. 52001-23-31-000-1994-5950-01(12054). C.P. Dr. Germán Rodríguez Villamizar.

------. Sala de lo Contencioso-Administrativo. Sección Tercera. Sentencia del 8 de agosto de 2002, expediente No. 10952, C.P. Dr. Ricardo Hoyos Duque.

-------. Sala de lo Contencioso-Administrativo. Sección Tercera. Sentencia del 28 de noviembre de 2002, expediente No. 70001-23-31-000-1993-4561-01(12812). C.P. Dr. Ricardo Hoyos Duque.

-------. Sala de lo Contencioso-Administrativo. Sección Tercera. Sentencia del 10 de julio de 2003, expediente No. 14083, C.P. Dra. María Elena Giraldo Gómez.

-------. Sala de lo Contencioso-Administrativo. Sección Tercera. Sentencia del 23 de octubre de 2003, expediente No. 25000-23-26-000-1995-00580-01 (14211). C.P. Dr. Ramiro Saavedra Becerra.

-------. Sala de lo Contencioso-Administrativo. Sentencia del 24 de febrero de 2005, expediente No. 85001-23-31-000-1993-00074-01(14170). C.P. Dr. Ramiro Saavedra Becerra. 
-------. Sala de lo Contencioso-Administrativo. Sección Tercera. Sentencia del 16 de marzo de 2005, expediente No. 66001-23-31-000-2003-00425-01(27831). C.P. Dra. María Elena Giraldo Gómez.

-------. Sala de lo Contencioso-Administrativo. Sección Tercera. Sentencia del 28 de abril de 2005, expediente No. 23001-23-31-000-1997-08423-01(16175). C.P. Dr. Ramiro Saavedra Becerra

------. Sala de lo Contencioso-Administrativo. Sección Tercera. Sentencia del 9 de junio de 2005, expediente No. 15260. C.P. Dra. María Elena Giraldo Gómez.

------. Sala de lo Contencioso-Administrativo. Sección Tercera. Sentencia del 6 de julio de 2005, expediente No. 13949, C.P. Dr. Alier Eduardo Hernández Enriquez.

-------. Sala de lo Contencioso-Administrativo. Sección Tercera. Sentencia del $1^{0} \stackrel{ }{ }$ de agosto de 2005, expediente No. 16205, C.P. Dra. María Helena Giraldo

-------. Sala de lo Contencioso-Administrativo. Sección Tercera. Sentencia del 10 de agosto de 2005, expediente No. 15127, C.P. Dra. María Elena Giraldo Gómez.

-------. Sala de lo Contencioso-Administrativo. Sección Tercera. Sentencia del 10 de agosto de 2005, expediente No. 15001-23-31-000-1990-10957-01(15338), C.P. Dra. Ruth Stella Correa Palacio.

-------. Sala de lo Contencioso-Administrativo. Sección Tercera. Sentencia del 5 de diciembre de 2005, expediente No. 13339, C.P. Dr. Alier Eduardo Hernández Enríquez

-------. Sala de lo Contencioso-Administrativo. Sección Tercera. Sentencia del 13 de diciembre 13 de 2005, expediente No. 24671, C.P. Dr. Alier Eduardo Hernández Enríquez. 
------. Sala de lo Contencioso-Administrativo. Sección Tercera. Sentencia del 1 de marzo de 2006, expediente No. 17256, C.P. Dra. María Elena Giraldo Gómez.

------. Sala de lo Contencioso-Administrativo. Sección Tercera. Sentencia del 11 de mayo de 2006, expediente No. 68001-23-15-000-1995-00935-01(14400). C.P. Dr. Ramiro Saavedra Becerra.

-------. Sala de lo Contencioso-Administrativo. Sección Tercera. Sentencia del 11 de mayo de 2006, expediente No. 14694, C.P. Dr. Ramiro Saavedra Becerra.

------. Sala de lo Contencioso-Administrativo. Sección Tercera. Sentencia del 24 de junio de 2006, expediente No. 13108, C.P. Dr. Ricardo Hoyos Duque.

-------. Sala de lo Contencioso-Administrativo. Sección Tercera. Sentencia del 31 de agosto de 2006, expediente No. 19432, C.P. Dra. Ruth Stella Correa Palacio

-------. Sala de lo Contencioso-Administrativo. Sección Tercera. Sentencia 30 de noviembre de 2006, expediente No. 15473 C.P. Dr. Alier Eduardo Hernández Enríquez.

-------. Sala de lo Contencioso-Administrativo. Sección Tercera. Sentencia del 7 de marzo de 2007, expediente No. 16341, C.P. Dr. Enrique Gil Botero.

------. Sala de lo Contencioso-Administrativo. Sección Tercera. Sentencia del 8 de marzo de 2007, expediente No. 15739, C.P. Dr. Ramiro Saavedra Becerra.

-------. Sala de lo Contencioso-Administrativo. Sección Tercera. Sentencia del 2 de mayo de 2007, expediente No. 20585, C.P. Dr. Mauricio Fajardo Gómez

------. Sala de lo Contencioso-Administrativo. Sección Tercera. Sentencia del 31 de mayo de 2007, expediente No. 76001-23-25-000-1996-02792-01(16898). C.P. Dr. Enrique Gil Botero. 
-------. Sala de lo Contencioso-Administrativo. Sección Tercera. Sentencia del 6 de marzo de 2008, expediente No. 66001-23-31-000-1996-03099-01(14443). C.P. Dra. Ruth Stella Correa Palacio.

-------. Sala de lo Contencioso-Administrativo. Sección Tercera. Sentencia del 11 de febrero de 2009, expediente No. 63001-23-31-000-1998-00622-00(16980). C.P. Dr. Mauricio Fajardo Gómez.

------. Sala de lo Contencioso-Administrativo. Sección Tercera. Sentencia del 25 de febrero de 2009, expediente No. 05001-23-26-000-1991-06265-01(17303) C.P. Dra. Ruth Stella Correa Palacio.

-------. Sala de lo Contencioso-Administrativo. Sección Tercera. Sentencia del 26 de marzo de 2014, expediente No. 25000-23-26-000-2003-00175-01 (28.741). C.P. Dr. Enrique Gil Botero.

-------. Sala de lo Contencioso-Administrativo. Sección Tercera. Sentencia del 26 de marzo de 2014, expediente No. 44001-23-31-000-2001-00282-01(28864). C.P. Dr. Jaime Orlando Santofimio Gamboa.

-------. Sala de lo Contencioso-Administrativo. Sección Tercera. Sentencia del 27 de marzo de 2014, expediente 25000-23-26-000-2002-02117-01(29146). C.P. Dra. Stella Conto Díaz del Castillo.

-------. Sala Plena de lo Contencioso-Administrativo. Sentencia del 25 de agosto de 1998, expediente IJ-001, C.P. Dr. Jesús María Carrillo Ballesteros.

Colombia, Corte Constitucional. Sentencia C-004 de 1992, M.P. Dr. Eduardo Cifuentes Muñoz. 
------. Sentencia C-149 del 22 de abril de 1993, M.P. Dr. José Gregorio Hernández Galindo.

-------. Sentencia C-337 del 19 de agosto de 1993, M.P. Dr. Vladimiro Naranjo Mesa.

-------. Sentencia C-333 del 1ำ de agosto de 1996, M.P. Dr. Alejandro Martínez Caballero.

-------. Sentencia C-652 del 3 de diciembre de 1997, M.P. Dr. Vladimiro Naranjo Mesa.

------. Sentencia C-1062 del 16 de agosto de 2000, M.P. Dr. Álvaro Tafur Galvis.

-------. Sentencia C-832 del 8 de agosto de 2001, M.P. Dr. Rodrigo Escobar Gil.

-------. Sentencia C-892 del 22 de agosto de 2001, M.P. Dr. Rodrigo Escobar Gil.

------. Sentencia C-285 del 23 de abril de 2002, M.P. Dr. Jaime Córdoba Triviño.

-------. Sentencia C-1172 del 23 de noviembre de 2004, M.P. Dr. Clara Inés Vargas Hernández.

------. Sentencia C-038 del $1^{\circ}$ de febrero de 2006, M.P. Dr. Humberto Antonio Sierra Porto

-------. Sentencia C-189 del 15 de marzo de 2006, M.P. Dr. Rodrigo Escobar Gil

-------. Sentencia C-133 del 25 de febrero de 2009, M.P. Dr. Jaime Araújo Rentería.

------. Sentencia C-401 del 26 de mayo de 2010, M.P. Dr. Gabriel Eduardo Mendoza Martelo. 
-------. Sentencia C-644 del 31 de agosto de 2011, M.P. Dr. Jorge Iván Palacio Palacio.

-------. Sentencia C-415 de 6 de junio de 2012, M.P. Dr. Mauricio González Cuervo.

-------. Sentencia T-401 del 3 de junio de 1992, M.P. Dr. Eduardo Cifuentes Muñoz.

-------. Sentencia T-406 del 5 de junio de 1992, M.P. Dr. Ciro Angarita Barón.

-------. Sentencia T-499 del 21 de agosto de 1992, M.P. Dr. Eduardo Cifuentes Muñoz.

-------. Sentencia T-505 del 28 de agosto de 1992, M.P. Dr. Eduardo Cifuentes Muñoz.

-------. Sentencia T-532 del 23 de septiembre de 1992, M.P. Dr. Eduardo Cifuentes Muñoz.

-------. Sentencia T-533 del 23 de septiembre de 1992, M.P. Dr. Eduardo Cifuentes Muñoz.

------. Sentencia T-571 del 26 de octubre de 1992, M.P. Dr. Jaime Sanín Greiffenstein.

-------. Sentencia T-015 del 23 de enero de 1995, M.P. Dr. Hernando Herrera Vergara.

------. Sentencia T-352 del 30 de julio de 1997, M.P. Dr. Eduardo Cifuentes Muñoz.

-------. Sentencia T-389 del 27 de mayo de 1999, M.P. Dr. Carlos Gaviria Díaz.

------. Sentencia T-1634 del 22 de noviembre de 2000, M.P. Dr. Alejandro Martínez Caballero.

-------. Sentencia T-520 del 26 de junio de 2003, M.P. Dr. Rodrigo Escobar Gil. 
-------. Sentencia T-419 del 6 de mayo de 2004, M.P. Dr. Alfredo Beltrán Sierra.

------. Sentencia T-312 del 3 de mayo de 2010, M.P. Dr. Jorge Ignacio Pretelt Chaljub.

España, Tribunal Constitucional. Sentencia 111/1983.

------. Sentencia 166/1986.

------. Sentencia 227/1988.

-----. Sentencia 45/1989.

------. Sentencia 179/1994.

------. Sentencia 185/1995.

------. Sentencia 159/1997.

------. Sentencia 194/2000.

----. Sentencia 289/2000.

-----. Sentencia 54/2002.

-------. Sentencia 193/2004.

-----. Sentencia 295/2006.

España, Tribunal Supremo. Sala Tercera de lo Contencioso-Administrativo. Sentencia del 5 de marzo de 1993. 
-------. Sala Tercera de lo Contencioso-Administrativo. Sentencia del 27 de junio de 1994.

-------. Sala Tercera de lo Contencioso-Administrativo. Sentencia del 16 de diciembre de 1997.

-------. Sala Tercera de lo Contencioso-Administrativo. Sentencia del 29 de febrero de 2000.

-------. Sala Tercera de lo Contencioso-Administrativo. Sentencia del 13 de junio de 2000.

-------. Sala Tercera de lo Contencioso-Administrativo. Sentencia del 15 de julio de 2000.

-------. Sala Tercera de lo Contencioso-Administrativo. Sentencia del 14 de diciembre de 2000.

-------. Sala Tercera de lo Contencioso-Administrativo. Sentencia del 19 de diciembre de 2000.

-------. Sala Tercera de lo Contencioso-Administrativo. Sentencia del 22 de diciembre de 2000.

-------. Sala Tercera de lo Contencioso-Administrativo. Sentencia del 23 de diciembre de 2000 .

-------. Sala Tercera de lo Contencioso-Administrativo. Sentencia del 27 de diciembre de 2000 . 
--------. Sala Tercera de lo Contencioso-Administrativo. Sentencia del 17 de febrero de 2001.

-------. Sala Tercera de lo Contencioso-Administrativo. Sentencia del 24 de enero de 2002.

-------. Sala Tercera de lo Contencioso-Administrativo. Sentencia del 3 de julio de 2003.

------. Sala Tercera de lo Contencioso-Administrativo. Sentencia del 17 de julio de 2003.

Sala Tercera de lo Contencioso-Administrativo. Sentencia del 18 de septiembre de 2003.

-------. Sala Tercera de lo Contencioso-Administrativo. Sentencia del 29 de octubre de 2004.

-------. Sala Tercera de lo Contencioso-Administrativo. Sentencia del 11 de septiembre de 2007.

-------. Sala Tercera de lo Contencioso-Administrativo. Sentencia del 5 de marzo de 2008.

-------. Sala Tercera de lo Contencioso-Administrativo. Sentencia del 16 de diciembre de 2008.

-------. Sala Tercera de lo Contencioso-Administrativo. Sentencia del 24 de febrero de 2010. 
-------. Sala Tercera de lo Contencioso-Administrativo. Sentencia del 2 de junio de 2010.

-------. Sala Tercera de lo Contencioso-Administrativo. Sentencia del 17 de septiembre de 2010.

-------. Sala Tercera de lo Contencioso-Administrativo. Sentencia del 23 de diciembre de 2010.

------. Sala Tercera de lo Contencioso-Administrativo. Sentencia del 13 de enero de 2011.

-------. Sala Tercera de lo Contencioso-Administrativo. Sentencia del 14 de enero de 2011.

-------. Sala Tercera de lo Contencioso-Administrativo. Sentencias del 18 de enero de 2011, 8 casos acumulados.

-------. Sala Tercera de lo Contencioso-Administrativo. Sentencia de 5 de marzo de 2012.

-------. Sala Tercera de lo Contencioso-Administrativo. Sentencia del 2 de octubre de 2012.

Italia, Corte Constituzionale. Sentencia No. 7 de 1966.

-----. Sentencia No. 252 de 1983.

Unión Europea, Tribunal de Justicia. Sentencia del 16 de diciembre de 1960, caso C$6 / 60$. 
-------. Sentencia del 5 de febrero de 1963, caso 26/62.

-------. Sentencia del 15 de julio de 1964, caso 6/64.

------. Sentencia del 9 de marzo de 1978, caso 106/77.

-------. Sentencia del 19 de noviembre de 1991, casos acumulados C-6/90 y C-9/90.

-------. Sentencia de 5 de marzo de 1996, casos acumulados C-46/93 y C-48/93.

------. Sentencia de 26 de marzo de 1996, caso C-392/93.

-------. Sentencia de 5 de marzo de 1996, casos acumulados C-46/93 y C-48/93.

-------. Sentencia del 8 de octubre de 1996, casos acumulados C-178, 179 y 188/94.

-------. Sentencia del 1ํo de junio de 1999, caso C-302/97.

-------. Sentencia del 4 de julio de 2000, caso C-424/97.

------. Sentencia del 12 de diciembre de 2006, caso C-446-04.

------. Sentencia del 9 de julio de 2009, caso C-397/07. 